Prepared in cooperation with the Strategic Environmental Research and Development Program, U.S. Department of Defense

\title{
Water Resources on Guam-Potential Impacts of and Adaptive Response to Climate Change
}

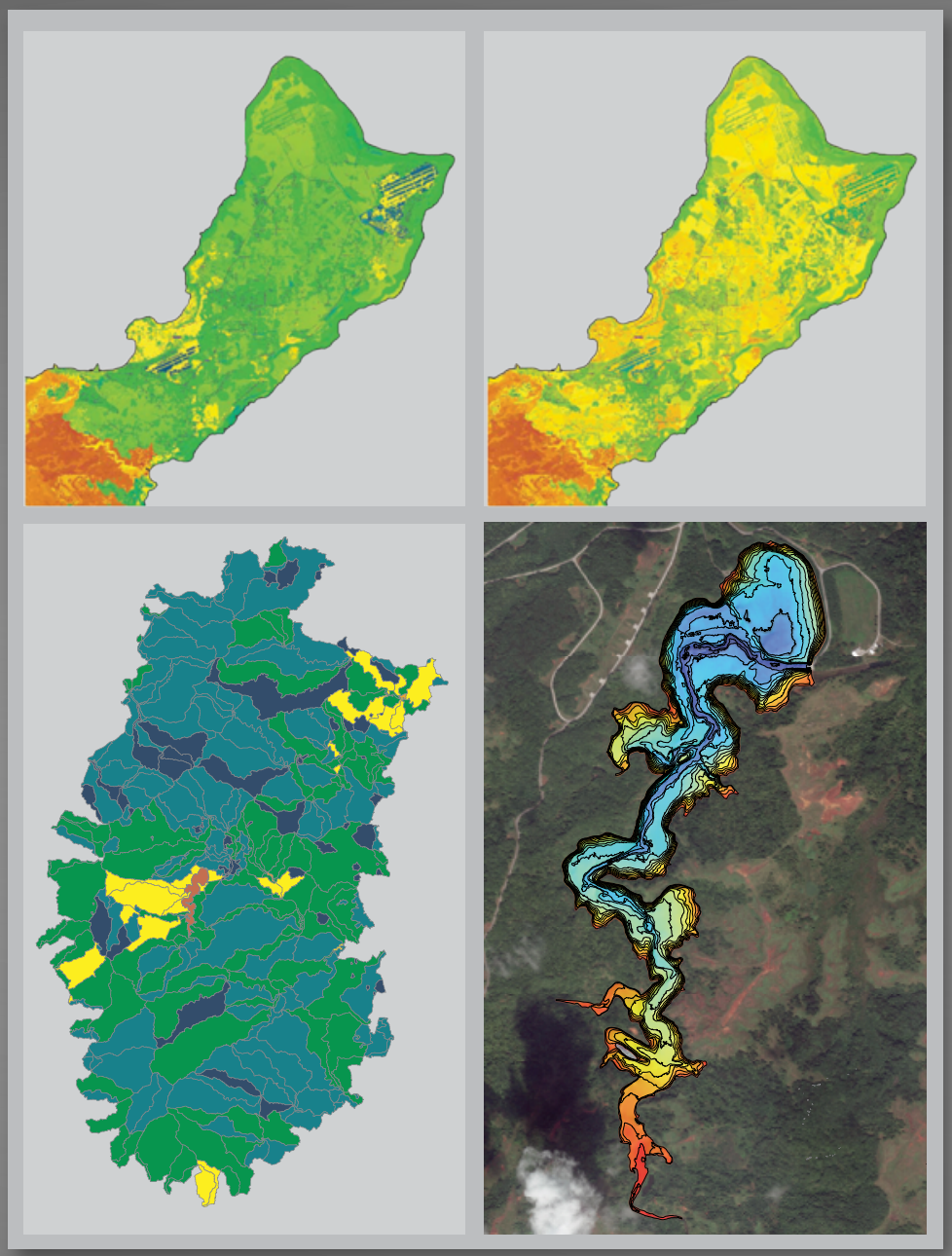

Scientific Investigations Report 2019-5095

U.S. Department of the Interior U.S. Geological Survey 


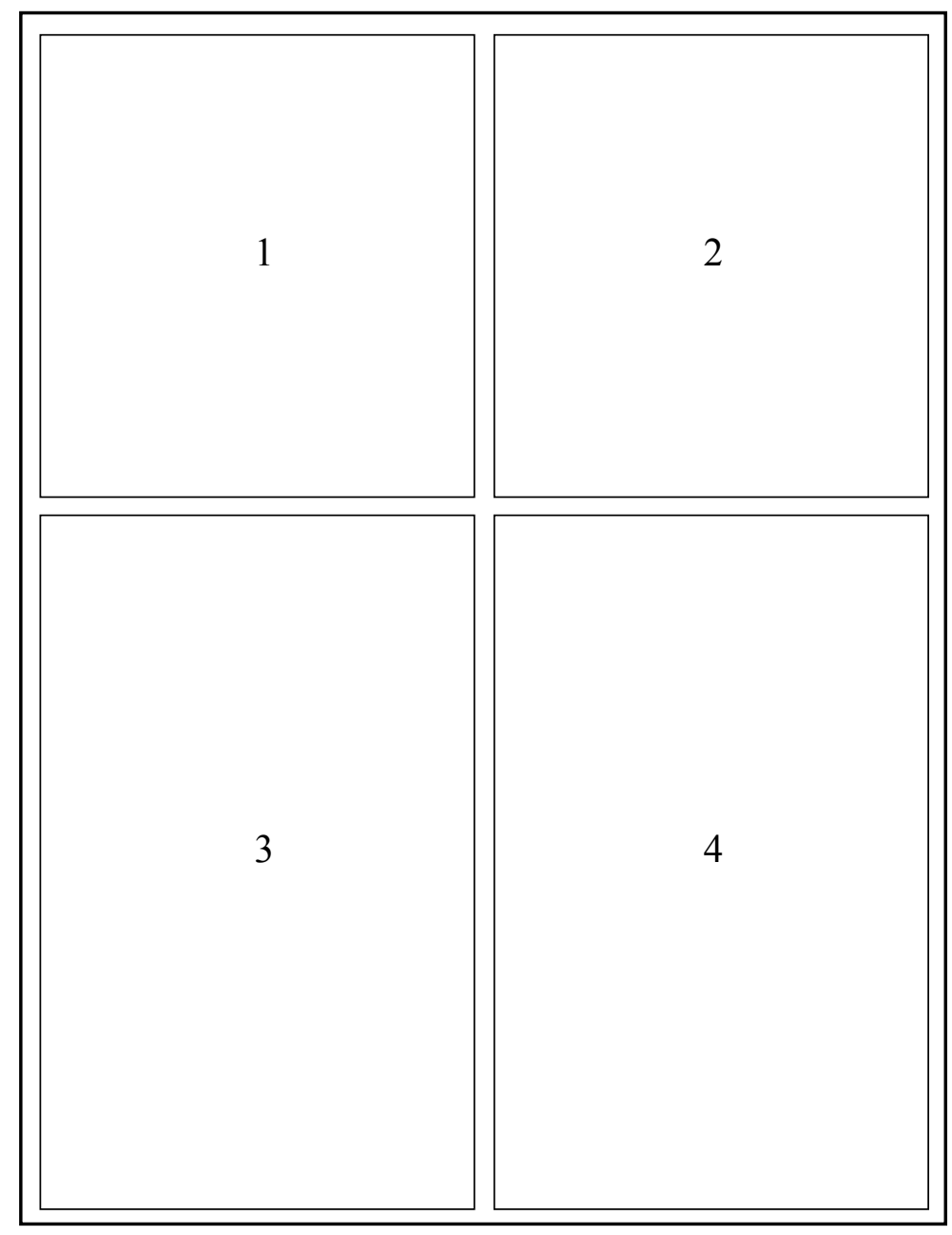

Cover. Mosaic of maps showing (1) the distribution of mean annual groundwater recharge estimated for the Northern Guam Lens Aquifer for the historic (1961-2005; modified from Johnson, 2012) and (2) future climate conditions (scenario Representative Concentration Pathway 8.5, 2080-90), (3) percentage streamflow change by hydrologic response unit in the PRMS_2016 model for the scenario Representative Concentration Pathway 8.5, and (4) bathymetry and contours of Fena Valley Reservoir, Guam. 


\section{Water Resources on Guam-Potential Impacts of and Adaptive Response to Climate Change}

By Stephen B. Gingerich, Adam G. Johnson, Sarah N. Rosa, Mathieu D. Marineau, Scott A. Wright, Lauren E. Hay, Matthew J. Widlansky, John W. Jenson, Corinne I. Wong, Jay L. Banner, Victoria W. Keener, and Melissa L. Finucane

Prepared in cooperation with the Strategic Environmental Research and Development Program, U.S. Department of Defense

Scientific Investigations Report 2019-5095 


\title{
U.S. Department of the Interior DAVID BERNHARDT, Secretary
}

\author{
U.S. Geological Survey \\ James F. Reilly II, Director
}

\section{U.S. Geological Survey, Reston, Virginia: 2019}

For more information on the USGS - the Federal source for science about the Earth, its natural and living resources, natural hazards, and the environment-visit https://www.usgs.gov or call 1-888-ASK-USGS.

For an overview of USGS information products, including maps, imagery, and publications, visit https://store.usgs.gov.

Any use of trade, firm, or product names is for descriptive purposes only and does not imply endorsement by the U.S. Government.

Although this information product, for the most part, is in the public domain, it also may contain copyrighted materials as noted in the text. Permission to reproduce copyrighted items must be secured from the copyright owner.

Suggested citation:

Gingerich, S.B., Johnson, A.G., Rosa, S.N., Marineau, M.D., Wright, S.A., Hay, L.E., Widlansky, M.J., Jenson, J.W., Wong, C.I., Banner, J.L., Keener, V.W., and Finucane, M.L., 2019, Water resources on Guam-Potential impacts of and adaptive response to climate change: U.S. Geological Survey Scientific Investigations Report 2019-5095, 55 p., https://doi.org/10.3133/sir20195095.

ISSN 2328-0328 (online) 


\section{Acknowledgments}

This project was funded by the U.S. Department of Defense's Strategic Environmental Research and Development Program (SERDP) under Project RC-2340. Delwyn Oki (USGS) and Esther Pischel (USGS) contributed numerous excellent suggestions and a timely review of our work. Use of trademark names does not imply USGS endorsement of products.

\section{Contents}

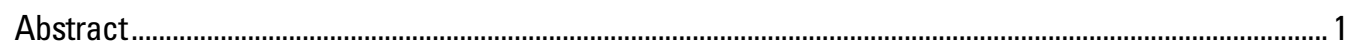

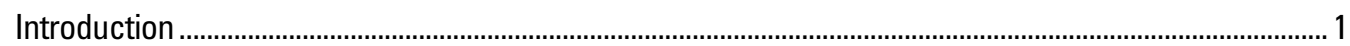

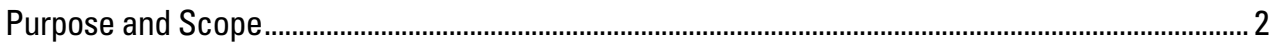

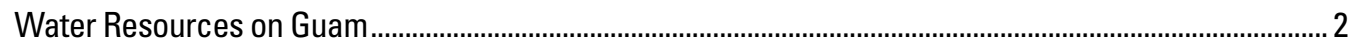

Surface-Water Resources in Southern Guam ............................................................................... 2

Groundwater Resources in Northern Guam ....................................................................................

Surface-Water and Groundwater Models for Guam ......................................................................... 4

Southern Guam Surface-Water Models .................................................................................... 4

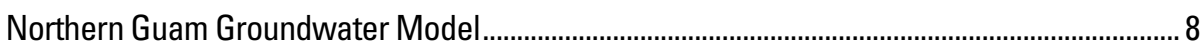

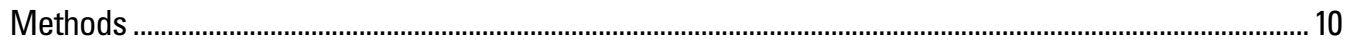

Projecting Future Climate ................................................................................................................ 10

Selecting Global Climate Models ......................................................................................... 10

Projecting Future Typhoon Occurrence ………………….................................................... 11

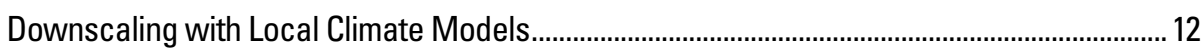

Estimating Future Sea Level.......................................................................................................... 12

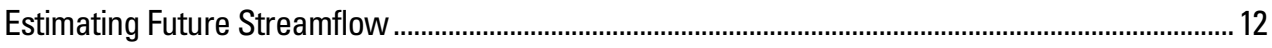

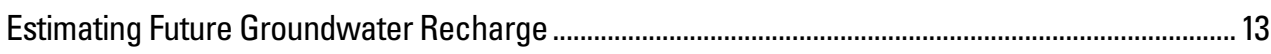

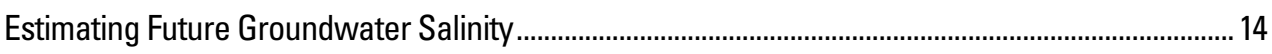

Results and Discussion ................................................................................................................... 14

Future Rainfall and Temperature ............................................................................................ 14

Projected Impacts on Surface-Water Resources ........................................................................... 18

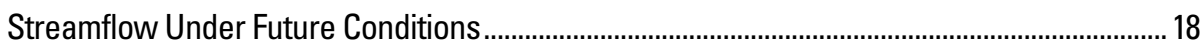

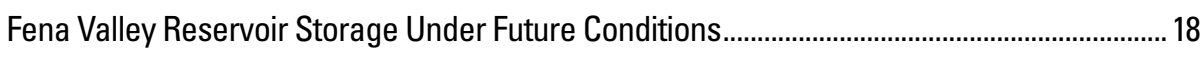

Fena Valley Reservoir Sedimentation Under Future Conditions ................................................. 21

Mitigation Strategies for Increasing Future Surface-Water Availability .......................................... 21

Lowering Fena Valley Reservoir Water-Supply Intake Elevation............................................... 21

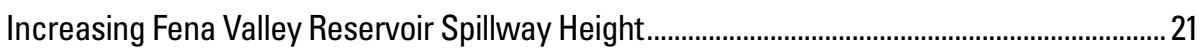

Lowering FVR Water-Supply Intake Elevation and Increasing FVR Spillway Height................21

Projected Impacts on Groundwater Resources...........................................................................22

Groundwater Conditions with Increased Sea Level ................................................................ 23

Groundwater Conditions with Decreased Recharge in a Future Climate .................................. 23

Groundwater Conditions with Increased Sea Level and Decreased Recharge in a

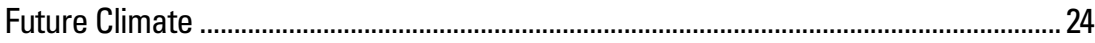

Mitigation Strategies to Reduce Produced-Water Salinity...........................................................25

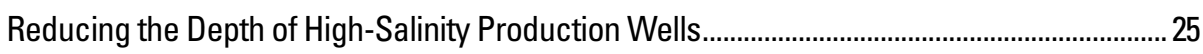

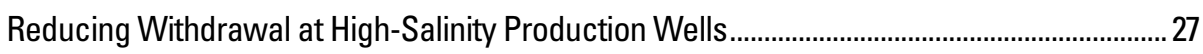


Reducing Well Depths and Withdrawal Rates ………………................................................... 27

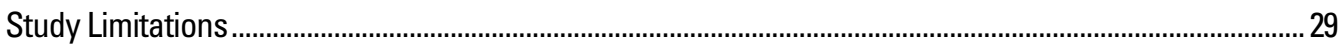

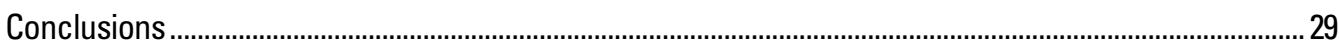

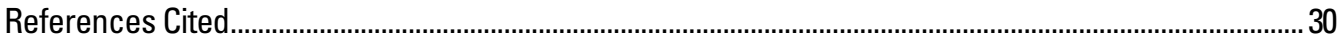

Appendix 1. Guam Water-Budget Models Used to Estimate Recharge ........................................................35

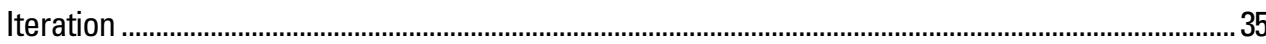

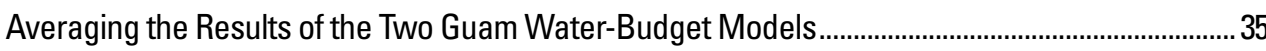

Captured Stormwater and its Allocation to Runoff or Recharge .......................................................35

Water-Budget Model Inputs for 1990-2009 Scenario ......................................................................... 36

Soil and Land-Cover Conditions................................................................................................. 36

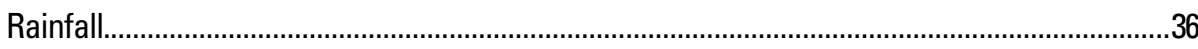

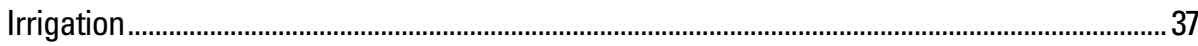

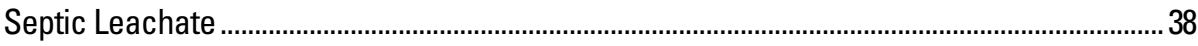

Water-Main Leakage ................................................................................................................. 38

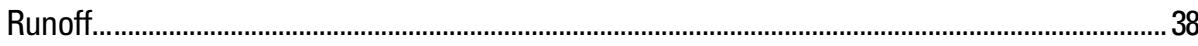

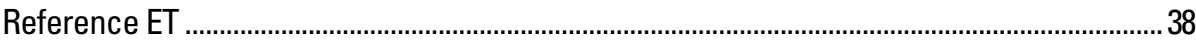

Using Modeled Climate Variables to Compute Change Factors for Simulating Rainfall and

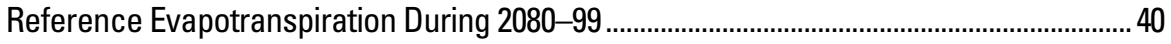

Water-Budget Model Inputs for 2080-99 Scenario ………….......................................................... 40

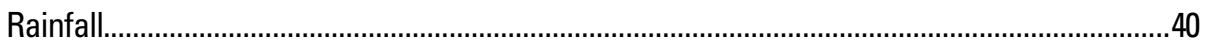

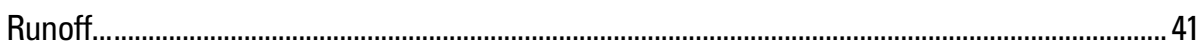

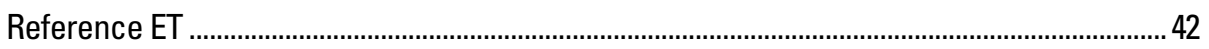

Appendix 2. Storage Capacity 5 Feet Above Spillway, Fena Valley Reservoir, Guam.................................. 43

Method 1-Extrapolation of the 2014 Stage-Capacity Curve ........................................................ 43

Method 2-Topographic Interpolation of 2013 Lidar Data Near Reservoir Shoreline ....................... 43

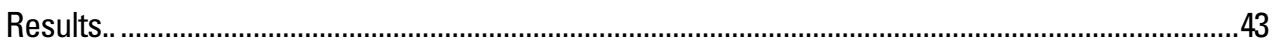

Appendix 3. Stakeholder Outreach and Response ................................................................................... 44

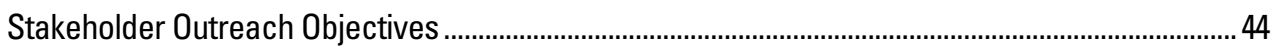

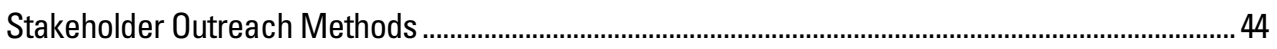

Overall Stakeholder Engagement Process............................................................................... 44

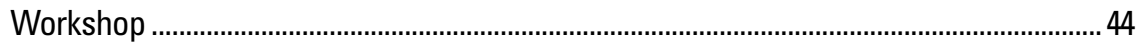

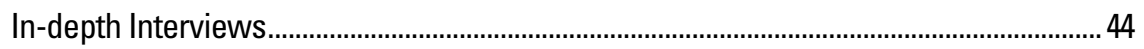

Stakeholder Outreach Results and Discussion .............................................................................. 45

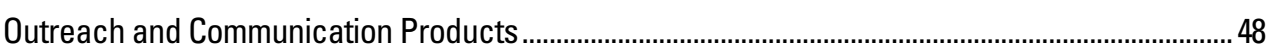

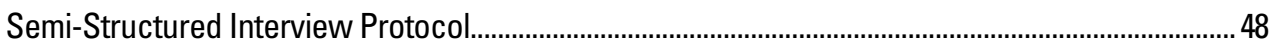

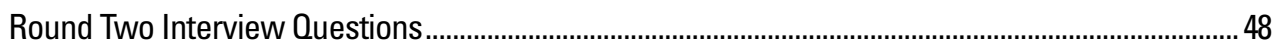

Part 1: Background Knowledge of Resources...................................................................... 48

Part 2: Usability of Tools and Figures.................................................................................... 50

Groundwater and Salinity Figures ................................................................................. 50

Fena Reservoir Management Figures.............................................................................53

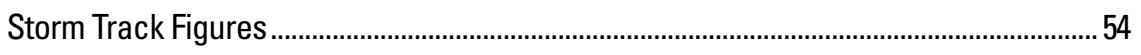

Questions Guiding the Interviews ................................................................................................ 55 


\section{Figures}

1. Location map of Guam showing the area underlain by the Northern Guam Lens Aquifer and the Fena Valley watershed and Reservoir.

2. Schematic cross section of the Northern Guam Lens Aquifer.................................................. 4

3. Diagram of the two-step modeling procedure for the Fena Valley watershed, Guam................ 5

4. Map of Guam showing modeled regions, model stream segments, and gaged drainage-basin areas in the PRMS_2016 model.

5. Map showing bathymetry and 5 -foot (1.5 meter) interval contours based on the February 2014 bathymetric survey of the Fena Valley Reservoir, Guam ..................................................... 7

6. Graphs showing stage-surface area and stage-capacity curves of Fena Valley Reservoir, Guam for 1951 and 2014.

7. Graph showing estimated change in capacity of the Fena Valley Reservoir due to sedimentation (Water Years 1952-2015)...

8. Model discretization and features for the numerical groundwater model mesh of the Northern Guam Lens Aquifer, Guam

9. Maps displaying global climate model historical biases of sea-surface temperature............. 11

10. Colorized shaded relief map showing the design of the three-step approach of the regional model experiments.

11. Example map showing inundation near Hagåtña Swamp due to a hypothetical 1.8-meter [6-feet] rise in sea level around Guam

12. Maps showing the change of seasonal average daily rainfall rates between the historical period and future scenario using the top five well-performing global climate model multimodel ensemble (MME) averages

13. Maps showing simulated change in rainfall and temperature during 2080-99 under scenario Representative Concentration Pathway (RCP) 8.5 compared to 1990-2009

14. Maps showing tropical cyclone (TC) genesis density and tracks determined by an objective assessment of simulated storms in the ERA-interim reanalysis.

15. Chart displaying the probability of tropical cyclone occurrence for observations (1979-2012), simulations of the historical period (1976-2005), and the future (RCP8.5) climate with greenhouse warming (2071-2100) around Guam

16. Regional maps showing projected change (2071-2100 minus 1976-2005) in simulated tropical cyclone genesis potential; maximum potential intensity change .

17. Map of southern Guam showing percentage streamflow change by hydrologic response unit (HRU) in the PRMS_2016 model for the scenario Representative Concentration Pathway 8.5

18. Bar chart table showing percentage of time monthly reservoir water levels are below or within each of the Fena Valley Reservoir water-conservation levels for selected waterwithdrawal rates

19. Maps showing the distribution of mean annual groundwater recharge estimated for the Northern Guam Lens Aquifer for historic (1961-2005) climate conditions and future (scenario Representative Concentration Pathway 8.5, 2080-99) climate conditions.

20. Graphs showing estimated mean monthly rainfall, artificial inflow (irrigation, water-main leakage, and septic-system leachate), total evapotranspiration, and recharge, future conditions (scenario Representative Concentration Pathway 8.5, 2080-99) for the northern aquifer sectors of Guam defined by Mink (1991). 
21. Graphs showing stable isotope values in water samples from Guam

22. Maps showing pumped wells with simulated salinity increases for future conditions (scenario Representative Concentration Pathway 8.5, 2080-99) in the Northern Guam Lens Aquifer, Guam

23. Map of withdrawal wells in which salinity would be reduced by shortening well depths or reducing withdrawal rates in the future (scenario Representative Concentration Pathway 8.5, 2080-99) recharge scenario, Northern Guam Lens Aquifer, Guam ..

24. Maps showing simulated salinity for future recharge (scenario Representative Concentration Pathway 8.5, 2080-99) at pumped wells in the Northern Guam Lens Aquifer, Guam.

\section{Tables}

1. List of global climate models analyzed and used as input data for the regional climatic models

2. Probability of exceeding Global Mean Sea Level (median value) scenarios in 2100 for the Representative Concentration Pathway 8.5 warming scenario)

3. Percentage of time monthly reservoir water levels are below or within each of the Fena Valley Reservoir water-conservation levels for selected water-withdrawal rates and climate conditions

4. Wells for which depth or withdrawal rate was modified for mitigation strategy simulations. 25

\section{Appendix Figures}

1.1. Mean monthly rainfall, expressed as uniform depths over the domain of the Guam models for 1990-2009 and 2080-99

2.1. Stage-capacity curve generated from the 2014 bathymetric survey of Fena Valley Reservoir, Guam

3.1. Sample image from Gingerich (2013) showing maps of simulated salinity at pumped wells in the Northern Guam Lens Aquifer, Guam for questions 12 through 14.

3.2. Sample image from Gingerich (2013) showing map of simulated freshwater discharge from the Northern Guam Lens Aquifer, Guam for questions 15 and 16

3.3. Sample image of table 5 from Gingerich (2013) that displays expected groundwater withdrawals under different military buildup and drought scenarios for questions 17 and 18

3.4. Sample image of table 2 from Rosa and Hay (2017a) that displays monthly and 12-month cumulative rainfall totals for the Fena watershed, Guam for question 19.

3.5. Sample image that shows the hypothetical water level of the Fena Reservoir during different notable climate events and over a 10-year average for questions 20 through 22

3.6. Sample image that shows a hypothetical climatology of observed tropical storm and typhon frequency from 1979 to 2012 for questions 23 and 24

3.7. Bar chart that shows the hypothetical frequency of tropical storms and typhoons for observations of 1979 to 2012 and simulations of the historical period of 1976 to 2005 and future climate of 2071-2100 with greenhouse warming for questions 25 and 26 


\section{Appendix Tables}

1.1 Annual weighting factors used to simulate interannual variability of rainfall and reference evapotranspiration (ET) in the Guam water-budget models for historic and future conditions

1.2. Mean monthly runoff-to-rainfall ratios assigned to runoff regions for the Guam water-budget models for the 1990-2009 scenario.

1.3. Mean monthly reference evapotranspiration values used to create inputs for the Guam water-budget models

1.4. Mean monthly runoff-to-rainfall ratios assigned to runoff regions of the Guam water-budget models for the 2080-2099 scenario.

3.1. Organizations and agencies represented at the February 2014 Guam workshop .................. 45

3.2. Examples of climate-sensitive decisions relevant to different Guam agencies and organizations

\section{Conversion Factors}

U.S. customary units to International System of Units

\begin{tabular}{|c|c|c|}
\hline Multiply & By & To obtain \\
\hline \multicolumn{3}{|c|}{ Length } \\
\hline inch (in.) & 2.54 & centimeter $(\mathrm{cm})$ \\
\hline inch (in.) & 25.4 & millimeter $(\mathrm{mm})$ \\
\hline foot $(\mathrm{ft})$ & 0.3048 & meter $(\mathrm{m})$ \\
\hline mile (mi) & 1.609 & kilometer $(\mathrm{km})$ \\
\hline \multicolumn{3}{|c|}{ Area } \\
\hline acre & 4,047 & square meter $\left(\mathrm{m}^{2}\right)$ \\
\hline acre & 0.004047 & square kilometer $\left(\mathrm{km}^{2}\right)$ \\
\hline square foot $\left(\mathrm{ft}^{2}\right)$ & 0.09290 & square meter $\left(\mathrm{m}^{2}\right)$ \\
\hline square mile $\left(\mathrm{mi}^{2}\right)$ & 2.590 & square kilometer $\left(\mathrm{km}^{2}\right)$ \\
\hline \multicolumn{3}{|c|}{ Volume } \\
\hline million gallons (Mgal) & 3,785 & cubic meter $\left(\mathrm{m}^{3}\right)$ \\
\hline acre-foot (acre-ft) & 1,233 & cubic meter $\left(\mathrm{m}^{3}\right)$ \\
\hline \multicolumn{3}{|c|}{ Flow rate } \\
\hline cubic foot per day $\left(\mathrm{ft}^{3} / \mathrm{d}\right)$ & 0.02832 & cubic meter per day $\left(\mathrm{m}^{3} / \mathrm{d}\right)$ \\
\hline gallon per day (gal/d) & 0.003785 & cubic meter per day $\left(\mathrm{m}^{3} / \mathrm{d}\right)$ \\
\hline \multicolumn{3}{|c|}{ Mass } \\
\hline ton per year (ton/yr) & 0.9072 & metric ton per year \\
\hline \multicolumn{3}{|c|}{ Density } \\
\hline pound per cubic foot $\left(\mathrm{lb} / \mathrm{ft}^{3}\right)$ & 16.02 & kilogram per cubic meter $\left(\mathrm{kg} / \mathrm{m}^{3}\right)$ \\
\hline \multicolumn{3}{|c|}{ Hydraulic conductivity } \\
\hline foot per day (ft/d) & 0.3048 & meter per day $(\mathrm{m} / \mathrm{d})$ \\
\hline
\end{tabular}

Temperature in degrees Celsius $\left({ }^{\circ} \mathrm{C}\right)$ may be converted to degrees Fahrenheit $\left({ }^{\circ} \mathrm{F}\right)$ as ${ }^{\circ} \mathrm{F}=\left(1.8 \times{ }^{\circ} \mathrm{C}\right)+32$.

Temperature in degrees Fahrenheit $\left({ }^{\circ} \mathrm{F}\right)$ may be converted to degrees Celsius $\left({ }^{\circ} \mathrm{C}\right)$ as ${ }^{\circ} \mathrm{C}=\left({ }^{\circ} \mathrm{F}-32\right) / 1.8$. 


\section{Datum}

Vertical coordinate information is referenced to Guam Vertical Datum of 2004 (GUVD04) and is informally called mean sea level in this report.

Horizontal coordinate information is referenced to the World Geodetic System of 1984 (WGS 84).

Elevation, as used in this report, refers to distance above the vertical datum.

\section{Abbreviations}

$\begin{array}{ll}\text { CMIP5 } & \text { Coupled Model Inter-Comparison Project, phase } 5 \\ \text { DPW } & \text { Guam Department of Public Works } \\ \text { DoD } & \text { U.S. Department of Defense } \\ \text { ENSO } & \text { El-Niño Southern Oscillation } \\ \text { EPA } & \text { U.S. Environmental Protection Agency } \\ \text { ET } & \text { evapotranspiration } \\ \text { FVR } & \text { Fena Valley Reservoir } \\ \text { FVR_2016 } & \text { Fena Valley Reservoir water-balance model updated for this study } \\ \text { GCM } & \text { global climate model } \\ \text { GEPA } & \text { Guam Environmental Protection Agency } \\ \text { GMSL } & \text { global mean sea level } \\ \text { GPA } & \text { Guam Power Authority } \\ \text { GWA } & \text { Guam Waterworks Authority } \\ \text { HRU } & \text { hydrologic response unit } \\ \text { IBTrACS } & \text { International Best Track Archive for Climate Stewardship } \\ \text { MME } & \text { multimodel ensemble } \\ \text { NAVFAC } & \text { Naval Facilities (Marianas or Pacific) } \\ \text { NGLA } & \text { Northern Guam Lens Aquifer } \\ \text { PET } & \text { potential evapotranspiration } \\ \text { PDO } & \text { Pacific decadal oscillation } \\ \text { PRMS } & \text { precipitation-runoff modeling system } \\ \text { PRMS_2016 } & \text { precipitation-runoff modeling system model for southern Guam updated for this study } \\ \text { RCP } & \text { Representative Concentration Pathway } \\ \text { RR } & \text { runoff-to-rainfall } \\ \text { SST } & \text { sea-surface temperature } \\ \text { SUTRA } & \text { USGS Saturated-Unsaturated Transport model } \\ \text { TRACK } & \text { An objective tropical cyclone tracking algorithm } \\ \text { USGS } & \text { United States Geological Survey } \\ \text { WERI } & \text { Water and Environmental Research Institute of the Western Pacific } \\ \text { WRF } & \text { weather research and forecast } \\ & \end{array}$




\title{
Water Resources on Guam-Potential Impacts of and Adaptive Response to Climate Change
}

\author{
By Stephen B. Gingerich, Adam G. Johnson, Sara N. Rosa, Mathieu D. Marineau, Scott A. Wright, Lauren \\ E. Hay, Matthew J. Widlansky, John W. Jenson, Corinne I. Wong, Jay L. Banner, Victoria W. Keener, and \\ Melissa L. Finucane
}

\section{Abstract}

The goals of this joint U.S. Geological Survey, University of Hawai'i, University of Guam, University of Texas, and East-West Center study were to (1) provide basic understanding about water resources for U.S. Department of Defense installations on Guam and (2) assess the resulting effect of sea-level rise and a changing climate on freshwater availability, on the basis of historic information, sea-level rise projections, and global-climate model temperature and rainfall projections. Downscaled regional climate models, informed by a multimodel ensemble of global climate models provided projections of future climate conditions for Guam. These projected climate conditions provided input to surface-water and groundwater models developed for Guam's hydrology. Guam's water resources in a future climate condition (2080-99) are projected to diminish relative to the recent climate condition. Projected average temperature increases, and average rainfall decreases will lead to reduced streamflow in southern Guam and reduced groundwater recharge to the Northern Guam Lens Aquifer (NGLA). Projected average temperatures in southern Guam will increase about $5.8^{\circ} \mathrm{F}\left(3.22^{\circ} \mathrm{C}\right)$, overall rainfall will decrease about 7 percent, and streamflow will consequently decrease 18 percent in important areas of southern Guam. Similarly, across the NGLA, future groundwater recharge will be 19 percent less than estimated recharge from 2012. Reduced future streamflow will decrease water availability from the Fena Valley Reservoir; however, the reservoir is expected to be able to supply water at recent demand rates without lowering the reservoir level to the elevation of the water-supply intakes throughout the simulated period of a future climate. A twelveyear simulation indicates that the reservoir can supply about twice the 2018 demand without lowering the reservoir level to the water-supply intakes. By following mitigation strategies to increase reservoir water availability, the withdrawal rate can be increased by 1.7 percent if the water-supply intakes are lowered $5 \mathrm{ft}$, by 3.5 percent if the spillway height is raised $5 \mathrm{ft}$, and by 5.3 percent if both strategies are combined. Higher sea level and reduced future recharge will decrease water availability from the NGLA. An index of composite chloride concentration from production wells increases to 300 milligrams per liter (mg/L) for future climate conditions and at 2010 withdrawal rates, compared with $130 \mathrm{mg} / \mathrm{L}$ under historic climate conditions. Most of this increase is due to reduced recharge as higher $(+3.2 \mathrm{ft})$ sea level only has a small role in increasing withdrawn water salinity. A redistributed withdrawal scenario in which the composite chloride concentration is $290 \mathrm{mg} / \mathrm{L}$ offers only slight improvement. Should future droughts reduce recharge proportionally to the decreases observed during historic droughts, the composite concentration would be about $900 \mathrm{mg} / \mathrm{L}$, and more than 70 percent of Guam's production wells would produce water with a composite concentration greater than 500 $\mathrm{mg} / \mathrm{L}$. Potential mitigation strategies for increasing the potable yield of the NGLA in a future climate include reducing depths of deep production wells and reducing the withdrawal rates in selected wells projected to have higher chloride concentrations. Simulations show both strategies are effective in lowering the composite concentration of the withdrawn water.

\section{Introduction}

On account of historical and projected population growth, freshwater demand on Guam has increased in the past and will likely increase in the future. During the early 1970s to 2010, groundwater withdrawals from the limestone of the Northern Guam Lens Aquifer (NGLA), the main freshwater source on the island, nearly tripled to almost 45 million gallons per day (Mgal/d) (Gingerich, 2013). Because of a proposed military relocation to Guam and expected population growth, freshwater demand on Guam is projected to increase further. Added to this projected demand are the potential adverse climate-change effects to Guam's surface-water and groundwater resources on which U.S. Department of Defense (DoD) installations and the civilian Guam Waterworks Authority (GWA) rely to supply the island's population. Changes in sea level, rainfall, and evapotranspiration, along with changing typhoon frequency and intensity, will affect streamflow, sediment loads, groundwater recharge, and salinity of groundwater withdrawn from wells. 
A joint U.S. Geological Survey (USGS), University of Hawai' $i$, University of Guam, University of Texas, and East-West Center study was undertaken to (1) provide basic understanding about water resources for DoD installations on Guam and (2) assess, on the basis of historic information, sea-level rise predictions, global climate model (GCM) temperature and rainfall output, surface-water models, and a groundwater model, the effect of sea-level rise. This information is needed to develop climate-change adaptation plans for DoD infrastructure and associated water resources, as well as to develop adequate response strategies by providing the range of parameters under which infrastructure and freshwater supplies may realistically be threatened. As part of meeting study objectives, the availability of accessible information to local stakeholders interested in Guam's water resources was prioritized. These stakeholders provided insight into the questions and concerns that those tasked with managing DoD and civilian water-supply systems expressed, and stakeholders also provided insight into ways to most effectively present the results of this study.

\section{Purpose and Scope}

The primary objective of this joint investigation is to determine the influence of future climate and sea-level rise on the freshwater resources (surface-water and groundwater) of Guam. This report documents the methods and analyses used to evaluate how Guam's climate is projected to change and how this change may affect surface-water and groundwater resources using the Representative Concentration Pathway 8.5 (RCP8.5) (Intergovernmental Panel on Climate Change, 2013). Downscaled regional climate models, which were informed by a multimodel ensemble (MME) of global climate models, were developed for this study to provide projections of future climate conditions for Guam. Additional modeling of future typhoon occurrence and intensity was developed to provide estimates of future projected rainfall. These projected climate conditions (rainfall, temperature, and reference evapotranspiration) from the downscaled climate model provided input to surface-water and groundwater models developed for Guam's hydrology. In southern Guam, an updated bathymetric survey of the Fena Valley Reservoir provided data for improved stage-capacity and reservoir sedimentation models. A rainfall-runoff watershed model, calibrated to historic conditions, provided estimates of streamflow under projected future hydrologic conditions. These two surface-water models were then used together to project reservoir storage conditions under a variety of future surface-water withdrawal scenarios. In northern Guam, a water-budget model, using projected climate as input, provided estimates of future groundwater recharge supplying Guam's limestone aquifer. A companion geochemical study of rainfall and groundwater provided evidence to support the understanding of the recharge timing and mechanisms. These future recharge estimates provided an understanding of groundwater salinity under projected groundwater withdrawal and climate conditions. Finally, future effects to water-supply infrastructure and mitigative strategies to maximize the water resources were evaluated.

\section{Water Resources on Guam}

Guam, the largest $\left(546 \mathrm{~km}^{2}\left[98.1 \mathrm{mi}^{2}\right]\right)$ and southernmost of the Mariana Islands, lies in the tropical western Pacific Ocean (lat $13^{\circ} 26^{\prime} \mathrm{N}$., long $144^{\circ} 47^{\prime} \mathrm{E}$.) (fig. 1). The island is divided into northern and southern geographic provinces by the Adelup fault. The island's southern province consists primarily of rugged volcanic uplands and gently sloping foothills that have been cut by streams creating a surface-water dominated hydrographic setting (Tracey and others, 1964; Gingerich, 2003). The island's northern province is a broad limestone plateau bordered by steep cliffs and discontinuous coastal lowlands. Most of the plateau lacks stream channels, but it has many closed depressions and is a groundwaterdominated hydrographic setting underlain by the NGLA (Ward and others, 1965; Gingerich, 2003, Gingerich, 2013).

\section{Surface-Water Resources in Southern Guam}

The Fena Valley Reservoir (FVR) (fig. 1) is the DoD's primary water source for Naval Base Guam and the nearby civilian residents in villages near the base (Marineau and Wright, 2015). The FVR, behind an 85-ft high, 1,050-ft long earthen dam, has a total storage capacity of about 6,915 acrefeet and a surface area of 193 acres when at full capacity (Marineau and Wright, 2015). The water-supply intake is about $45 \mathrm{ft}$ below the dam's spillway. The FVR receives streamflow from the $5.89 \mathrm{mi}^{2}$ Fena Valley watershed (fig.1), which includes three gaged rivers, (Maulap, Almagosa [including inflow from Almagosa Springs], and Imong) and one ungaged area. The amount of water supplied from the Fena Valley watershed is estimated to have ranged from 3.7 to $13.5 \mathrm{Mgal} / \mathrm{d}$ and averaged 9.2 Mgal/d during 1990-2014 but averaged only $5.5 \mathrm{Mgal} / \mathrm{d}$ during 2010-14, because of reductions in water supplied by Almagosa Springs (at the time of publication, water-supply data had not been published by the U.S. Navy). Over time, sediment carried by streamflow into the FVR reduced the reservoir storage capacity, which resulted in a change in the relation between reservoir stage and storage capacity. FVR total storage capacity decreased about 17 percent or 1,450 acre-feet during 1951-2014 as a result of sediment input. The bulk of the sediment arrived rapidly (within 1-2 days) during the aftermath of typhoons that brought extreme rainfall to the watershed (Nakama, 1992; Marineau and Wright, 2017). Higher flow regimes are often associated with heavy rainfall and have led to instances in which the water flowing through the FVR was too turbid for use in the water supply (Fontaine, 2003). 
The GWA also diverts and treats surface water from the Ugum River (fig. 1) for public supply, which provides about 2.5 to $3.2 \mathrm{Mgal} / \mathrm{d}$ to the residents of southern Guam (Guam Waterworks Authority, 2017). The water treatment plant at Ugum has experienced increased operational costs and premature failure of treatment equipment due to high turbidity of the Ugum River water during periods of high streamflow (U.S. Environmental Protection Agency, 2016).

\section{Groundwater Resources in Northern Guam}

Guam's most important groundwater sources are from the freshwater lens of the NGLA, comprised of highly permeable limestone rocks (Ward and others, 1965; Jocson and others, 2002; Gingerich 2013; Rotzoll and others, 2013). Here, the water table is no more than six feet (1.8 meters) above sea level, and the hydraulic gradient is nearly flat. The "basal" freshwater

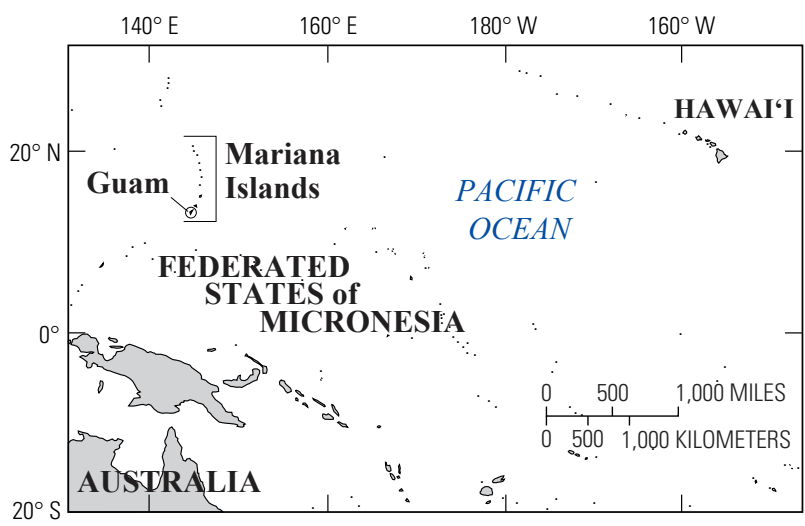

Base modified from U.S. Geological Survey 10-meter digital elevation model, Universal Tranverse Mercator projection, zone 55, WGS84 datum.

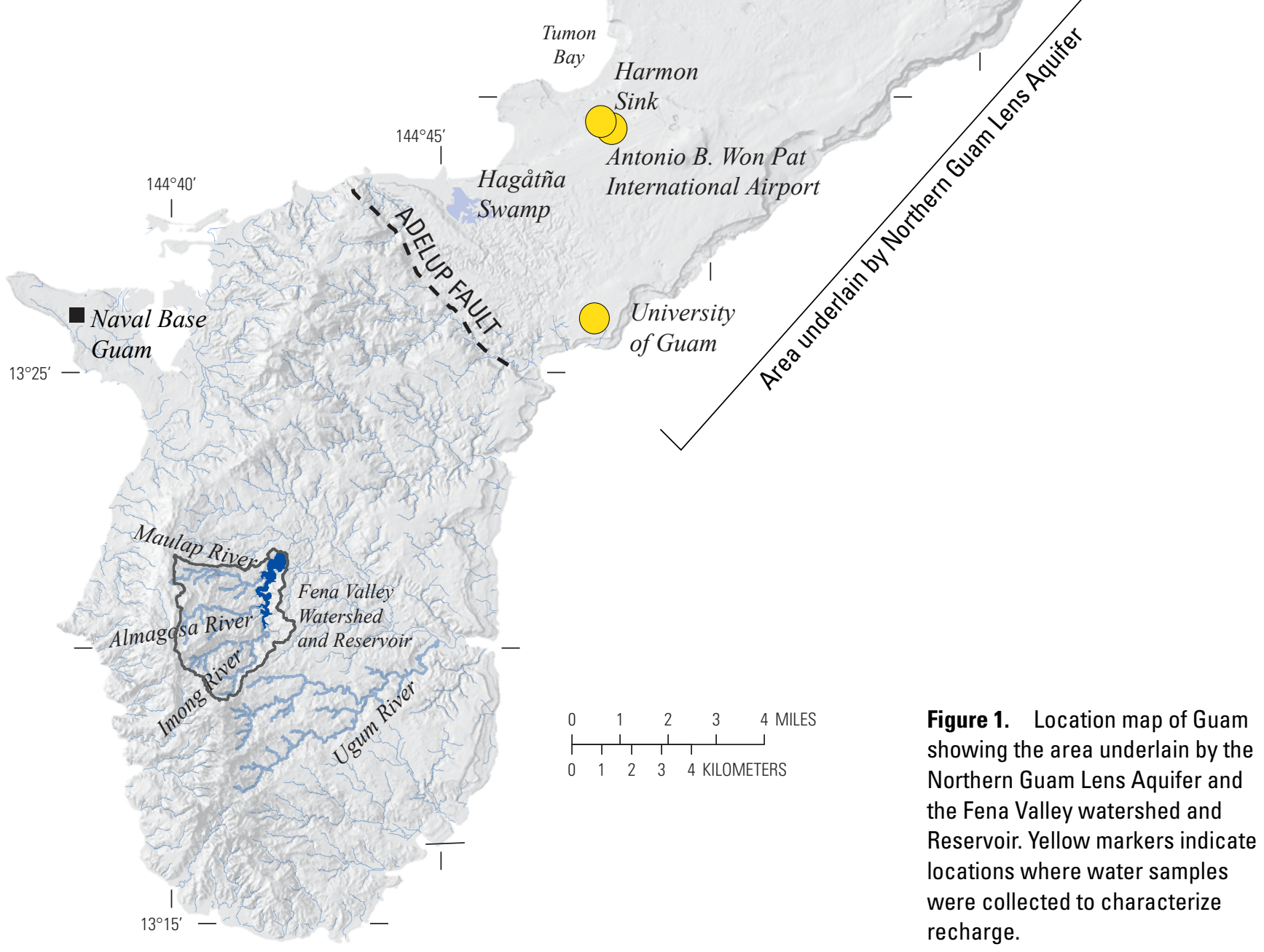


lens in these limestone rocks is relatively thin and is underlain by the saline water of the transition zone and further underlain by saltwater (fig. 2). The "para-basal" freshwater lens extends downward from the limestone into the low-permeability volcanic rocks underneath. This part of the freshwater lens is the prime target for groundwater development because it is less vulnerable to saltwater intrusion from below.

The geologically young, eogenetic limestone of northern Guam generally has extremely high permeability (Ward and others, 1965; Vacher and Mylroie, 2002). Faults transecting the plateau complicate the structure and regional permeability distribution of the aquifer (Mylroie and others, 2001; Jenson and others, 2006). In modeling studies, the regional horizontal hydraulic conductivity of the main limestone aquifer generally is estimated to be thousands of feet per day (Contractor and Srivastava, 1990; Jocson and others, 1999; Contractor and Jenson, 2000, Gingerich, 2013).

Recharge was estimated to be about $238 \mathrm{Mgal} / \mathrm{d}$ for the collective area of the six aquifer systems in northern Guam that represents the general area underlain by the NGLA (Johnson, 2012). Ninety-seven percent of recharge is from rainfall and the remainder is from irrigation, leaky water mains, and septic systems. Discharge from the NGLA occurs as withdrawals from wells, coastal springs, diffuse seepage to the ocean, and minor discharge to the Hagåtña Swamp. Average groundwater withdrawals in 2010 totaled about $42 \mathrm{Mgal} / \mathrm{d}$, which consists of about $36 \mathrm{Mgal} / \mathrm{d}$ withdrawn by the GWA, about $4 \mathrm{Mgal} / \mathrm{d}$ by the DoD, and about $1.8 \mathrm{Mgal} / \mathrm{d}$ by private wells; groundwater discharge to the ocean bordering the NGLA is estimated to be about $196 \mathrm{Mgal} / \mathrm{d}$ (Gingerich, 2013).

\section{Surface-Water and Groundwater Models for Guam}

Several models were used to evaluate Guam's water resources. In southern Guam, watershed and reservoir waterbalance models, published as part of this study (Rosa and Hay, 2017a), provided insight into the operation of the FVR. In northern Guam, an existing numerical groundwater model was available to evaluate how groundwater withdrawals affect salinity in the freshwater lens.

\section{Southern Guam Surface-Water Models}

To estimate future monthly FVR water levels in response to various combinations of projected water-withdrawal rates, a two-step modeling procedure was developed, documented in Rosa and Hay (2017a) (fig. 3). The first step uses a physically based, distributed-parameter watershed model known as a precipitationrunoff modeling system (PRMS) (Markstrom and others, 2015) that is designed to analyze the effects of rainfall, temperature, and land cover on streamflow in each of the hydrologic response units (HRUs). HRUs are areas in the watershed assumed to be homogeneous with regard to their physical properties and hydrologic response, and delineated for the southern Guam watershed model, PRMS_2016 (Rosa and Hay, 2017b) (fig. 4). The second step uses streamflow estimates from the PRMS_2016 model simulations as input to a separate reservoir water-balance model (FVR_2016) to estimate changes in FVR water levels. Both models were developed using streamflow and climatological data from 1951-2015 (Rosa and Hay, 2017a). Details of the PRMS 2016 and FVR 2016 model development are available in Rosa and Hay (2017a).

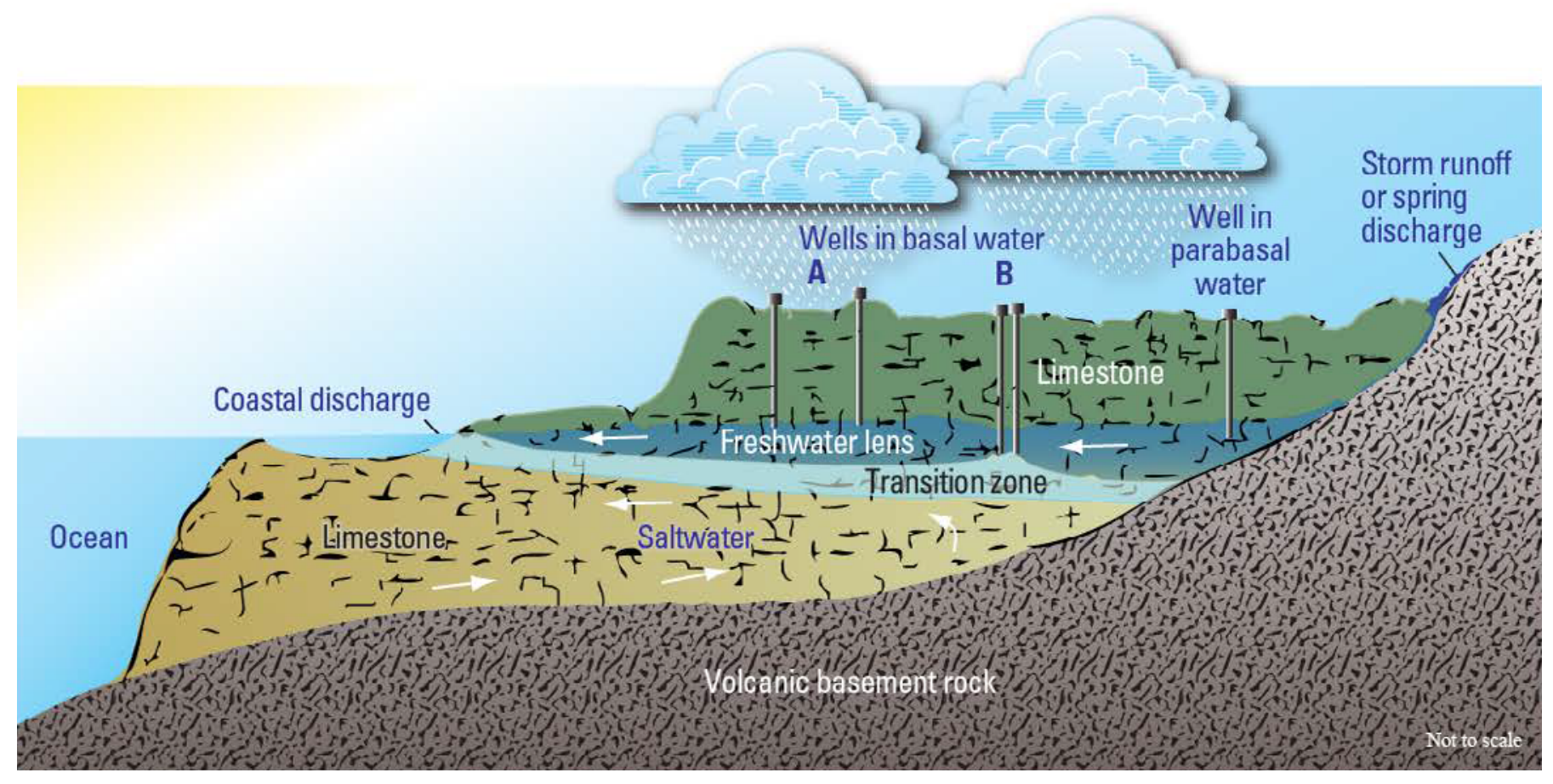

Figure 2. Schematic cross section of the Northern Guam Lens Aquifer (from Gingerich and Jenson, 2010). 


\section{Step 1: Estimate Streamflow}

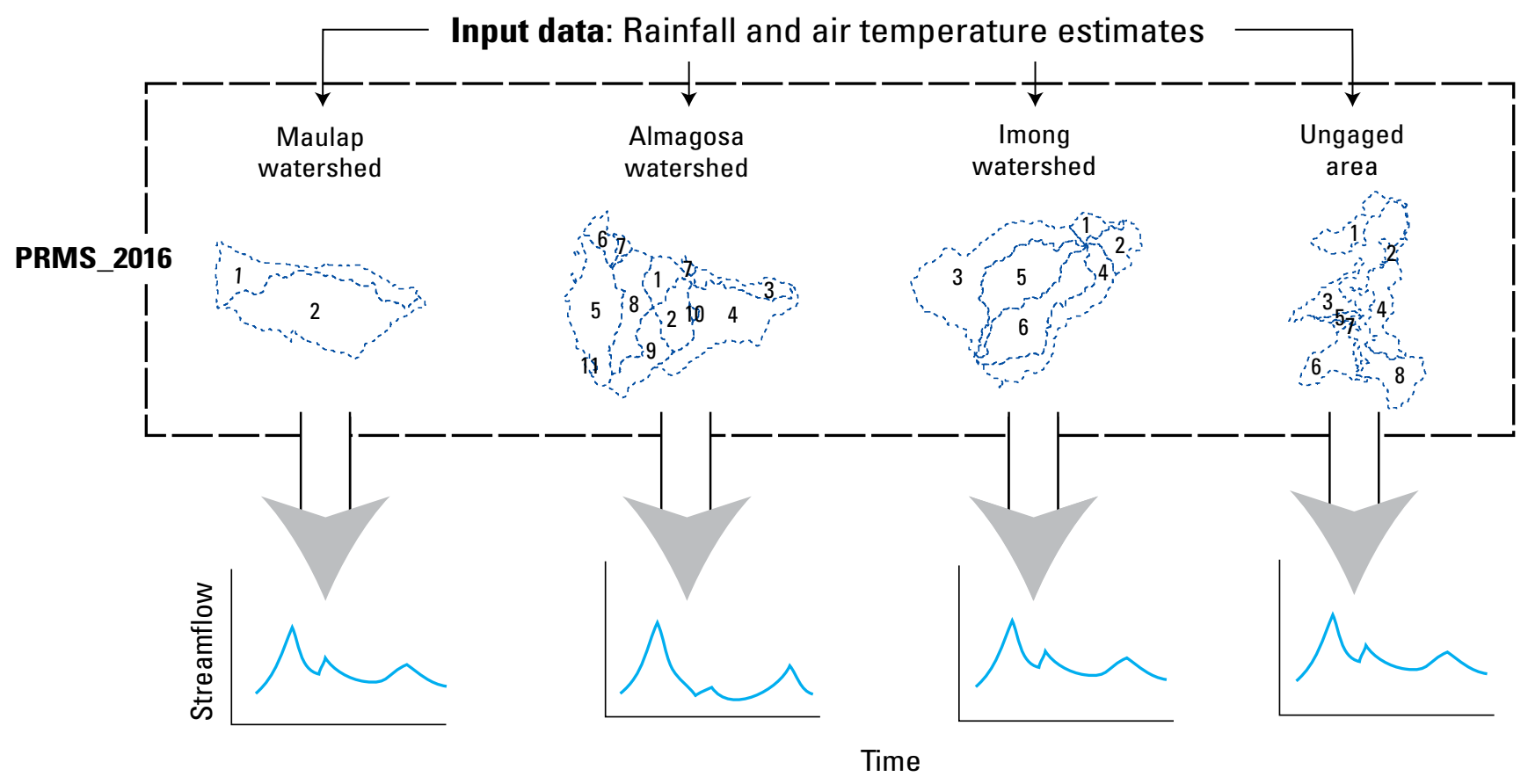

Step 2: Estimate Fena Valley Reservoir response

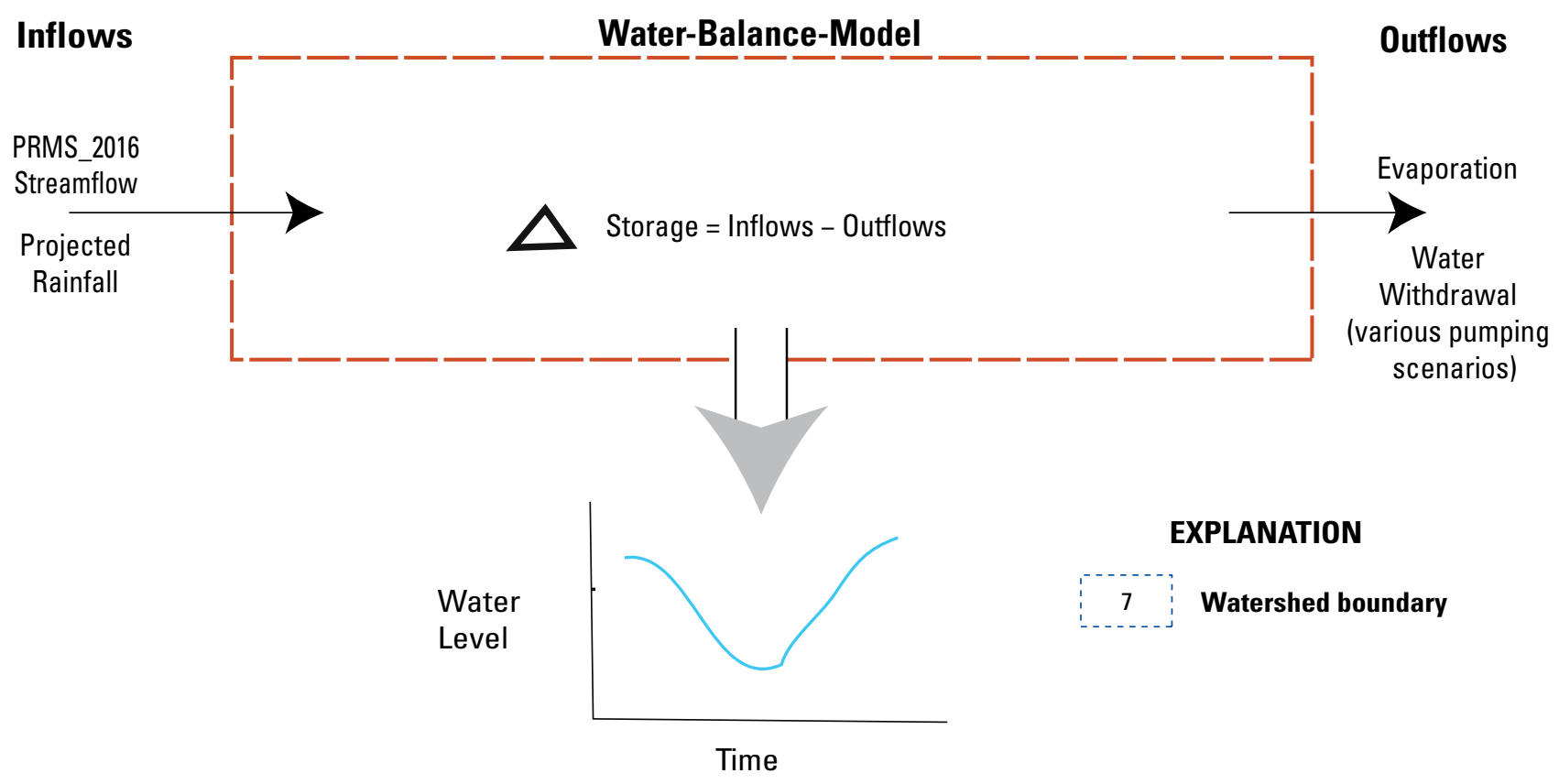

Figure 3. Diagram of the two-step modeling procedure for the Fena Valley watershed, Guam (from Rosa and Hay, 2017a; PRMS, Precipitation Runoff Modeling System). 
Figure 4. Map of Guam showing modeled regions, model stream segments, and gaged drainage-basin areas in the PRMS_2016 model (from Rosa and Hay, 2017a).
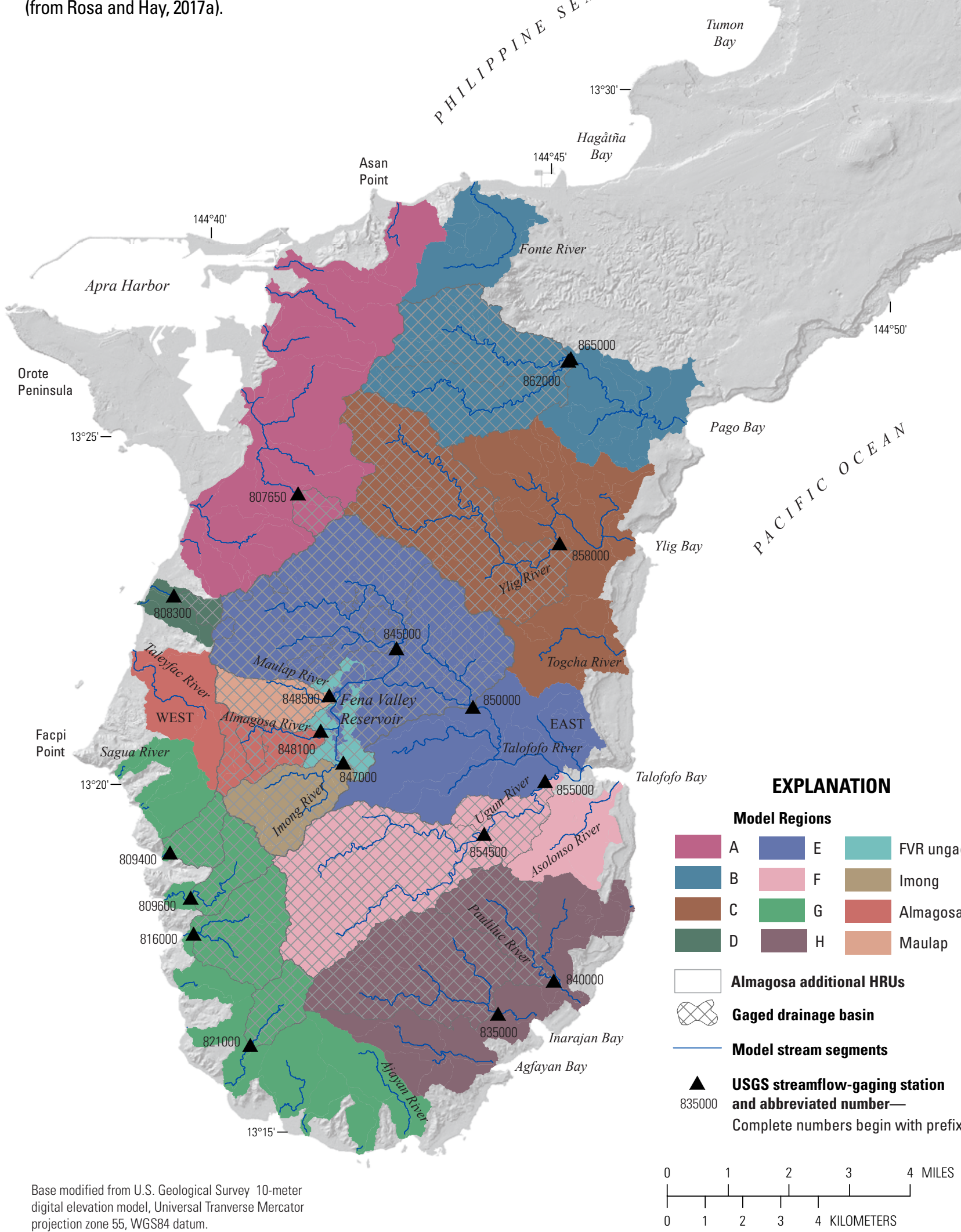
To estimate sedimentation of the FVR, a daily reservoir sedimentation model was developed (Marineau and Wright, 2017). Streamflow and sediment-load data from nearby stream gages, taken from 19512014, were incorporated into the model to obtain an initial estimate of sediment yield for the reservoir's watershed, which was then calibrated to the total deposition calculated from repeat bathymetric surveys. Details of the bathymetric survey of the FVR completed for this study (fig. 5) and the stage-area and stage capacity curves for the FVR (fig. 6) are available in Marineau and Wright (2015), and the daily reservoir sedimentation model developed from an analysis of this and previous bathymetric surveys are presented in Marineau and Wright (2017). The sedimentation model was applied to the FVR for the years 1951-2014. The total volume of sediment deposited between the 1951 survey and the 2014 survey was $6.6 \times 10^{7} \mathrm{ft}^{3}\left[1.87 \times 10^{6} \mathrm{~m}^{3}\right]$. Using an estimated sediment density of $85.7 \mathrm{lb} / \mathrm{ft}^{3}\left[1,373 \mathrm{~kg} / \mathrm{m}^{3}\right]$, the mass of sediment deposited in the reservoir was calculated as $2.8 \times 10^{6}$ tons $\left[2.57 \times 10^{6}\right.$ metric tons] (Marineau and Wright, 2017).

Results demonstrate the highly skewed nature of daily sediment deposition such that intense typhoondriven runoff events can contribute sediment volumes capable of reducing the overall reservoir capacity by as much as 3 percent in a few days (fig. 7). The model results were compared with reservoir deposition volumes computed from repeat bathymetric surveys, which provide an upper bound in expected model errors and survey measurement errors. The highest rate of deposition occurred during two typhoons (Typhoon Alice in 1953 and Typhoon Tingting in 2004), during which capacity decreased by about $2-3$ percent in only a few days.

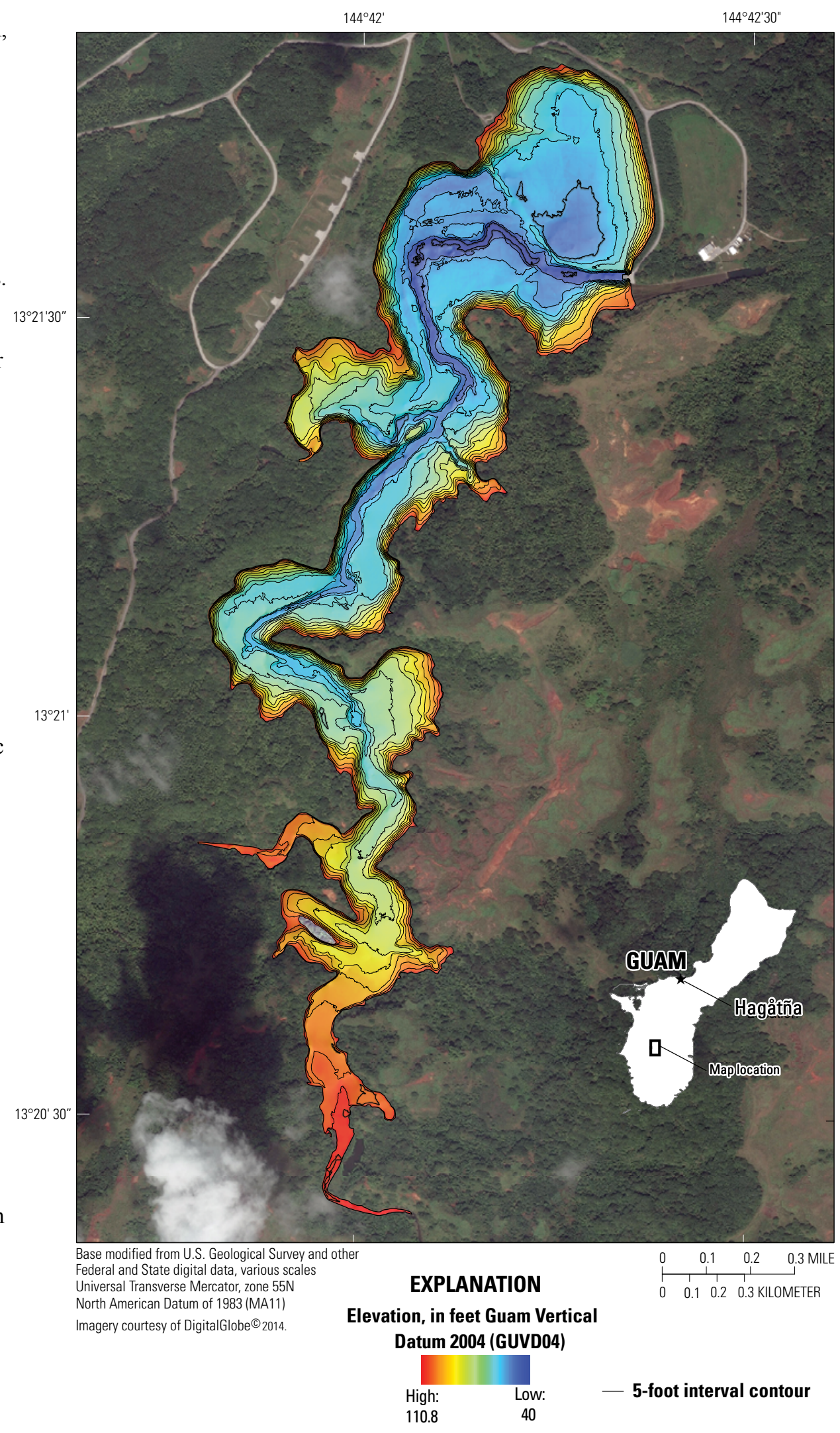

Figure 5. Map showing bathymetry and 5-foot (1.5 meter) interval contours based on the February 2014 bathymetric survey of the Fena Valley Reservoir, Guam. The color scale shows the deepest areas of the reservoir in dark blue (from Marineau and Wright, 2015). 

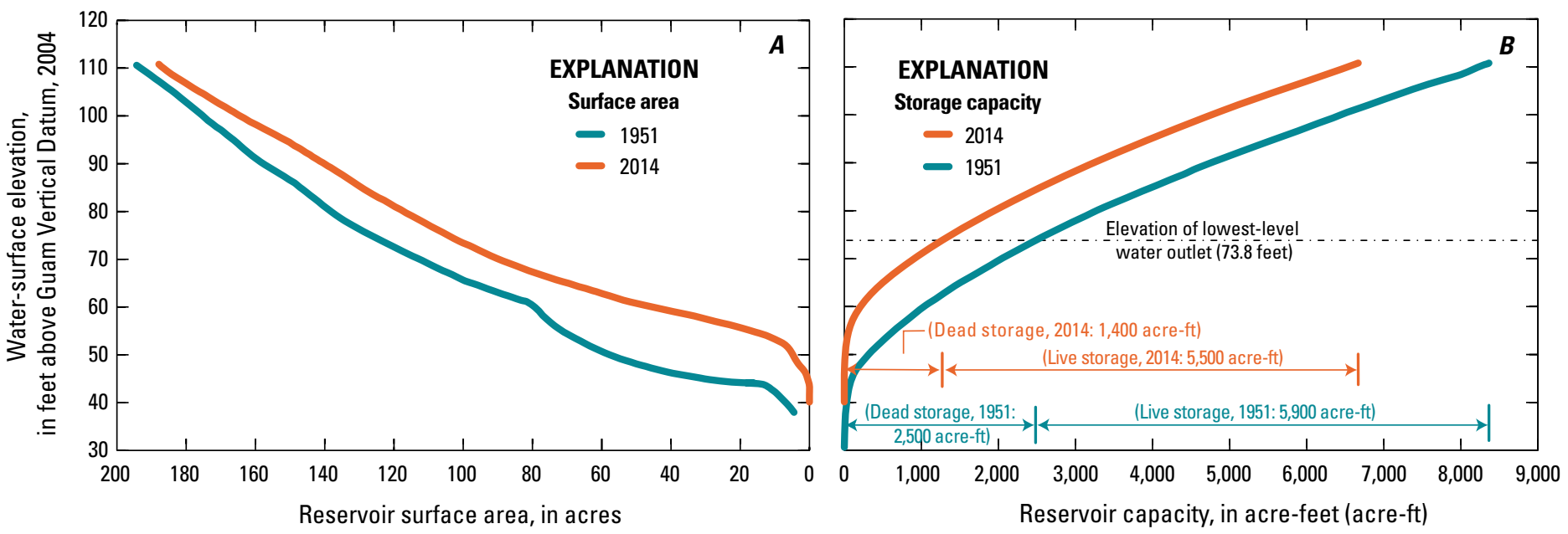

Figure 6. Graphs showing $(A)$ stage-surface area and $(B)$ and stage-capacity curves of Fena Valley Reservoir, Guam for 1951 and 2014. Stage-capacity curves with live and dead storage capacity in 1951 and 2014 are indicated (from Marineau and Wright, 2015).

Figure 7. Graph showing estimated change in capacity of the Fena Valley Reservoir due to sedimentation (Water Years 1952-2015). Typhoons associated with major sediment-producing runoff and historical surveys are labeled. Differences between model and historic survey results demonstrate survey and model error and highlight range of error in model predictions. Graph from Marineau and Wright, 2017.

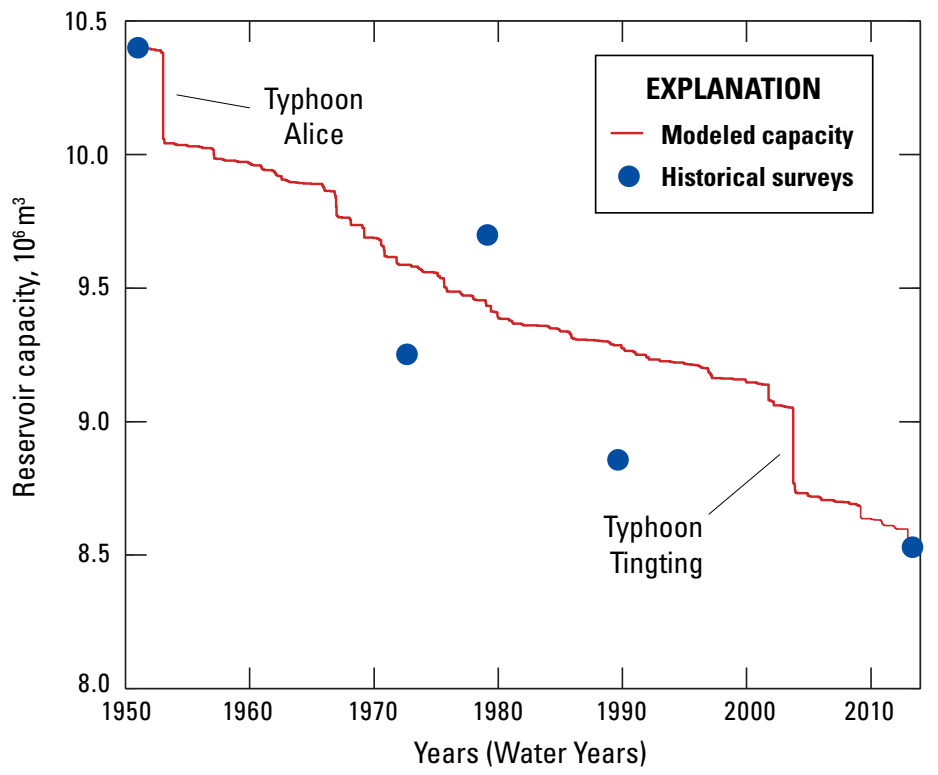

withdrawal scenarios (no withdrawal, withdrawal at 2010 rates, reduced withdrawal during drought, and increased withdrawal for selected growth projections). Simulations were designed on the basis of input from the DoD and GWA and for a drought scenario with about 32 percent less recharge than long-term average historic recharge. In general, the freshwater lens becomes smaller when withdrawal increases, or recharge is reduced. During drought, wells throughout the NGLA become more saline and the acceptable yield is reduced from $32 \mathrm{Mgal} / \mathrm{d}$ to $8.9 \mathrm{Mgal} / \mathrm{d}$ (Gingerich, 2013). 


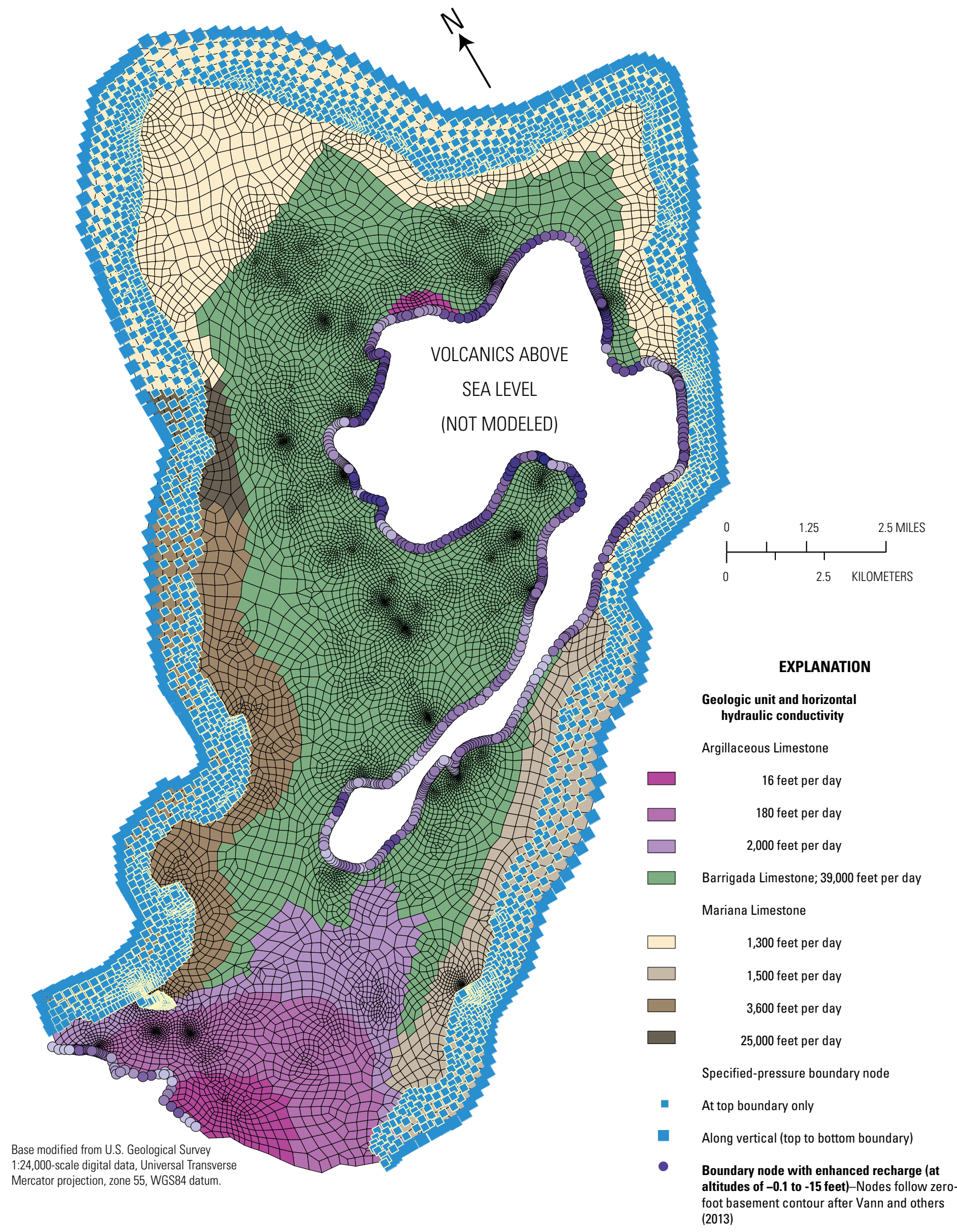

Figure 8. Model discretization and features for the numerical groundwater model mesh of the Northern Guam Lens Aquifer, Guam (from Gingerich, 2013). 


\section{Methods}

To determine future water-resource availability on Guam, spatially distributed estimates of future streamflow, groundwater recharge, and sea-level elevations in a future climate are needed. Future streamflow and recharge estimates were generated from modeled climate variables (rainfall, air temperature, and evaporation) for Guam during 2080-99 that were also estimated as part of this study through downscaling of climate models. To estimate future streamflow in southern Guam and future FVR water levels, future rainfall and air temperature inputs are needed for the surface-water models (Rosa and Hay, 2017a; Marineau and Wright, 2015; Marineau and Wright, 2017). Future recharge to the NGLA was estimated through a soil-water balance model (Johnson, 2012) using estimated future-climate variables and was applied to the existing groundwater model (Gingerich, 2013). Detailed descriptions of these elements are in the following section.

\section{Projecting Future Climate}

Projecting the likely future climate on Guam requires application of a variety of modeling techniques consisting of: (1) applying a set of objective metrics and selecting a subset of five well-performing GCMs from the Coupled Model Inter-Comparison Project, phase 5 (CMIP5) experiments, (2) examining the statistics of simulated future tropical typhoons over Guam, and (3) providing detailed climate projections for Guam through dynamical downscaling of an average of the selected well-performing GCMs to higher-resolution local climate models. The variables estimated by the local climate model for 2080-99 are for a warming scenario denoted RCP8.5, one of several future greenhouse radiative gas emission scenarios selected for use in the Intergovernmental Panel on Climate Change (2013) fifth assessment report. The RCP8.5 scenario reflects a high-emission, business-as-usual scenario (Riahi and others, 2011). The business-as-usual scenario assumes that future development trends follow those of the past and no changes in policies will take place. The methods used to develop the dynamical downscaling-derived climate projections that are described below were provided by the International Pacific Research Center (H. Annamalai, Senior Researcher) and the results were released in Zhang (2016).

\section{Selecting Global Climate Models}

Initial conditions for the regional climate model were generated from GCMs by comparison to Guam's climate history using a method published previously for the Pacific region (Widlansky and others, 2018; Storlazzi and others,
2018). Projecting hydro-climate conditions for the end of the current century is known to be associated with uncertainties. To reduce uncertainties, a subset of five well-performing GCMs (from a pool of 41) were selected (the process is described below) that best represent present-day rainfall and seasonal temperature climatologies and their annual cycle, as well as the relationship between the El Niño Southern Oscillation (ENSO) and rainfall at interannual timescales. This selection is based on the assumption that models that best represent the recent (1979-2005) climate and its variation are expected to provide a robust estimate of future climate and thereby reduce uncertainty. The regional-model experimental design warrants that only the current ENSO and Pacific Decadal Oscillation (PDO) conditions are maintained and assumes no changes to these variabilities in the future (a limitation of this pseudo-warming experimental design). A pseudo-warming experimental design is conducted by using a constant lateral boundary condition and adding the future change in the atmospheric field of a GCM to objective analysis data (Kimura and Kitoh, 2007). However, a focus on the longterm changes (trend) in climate variables is preserved. This 20 -year (yr) multimodel formulation is preferred because it accounts for projected end-of-century climate trends caused by changes in radiative forcing and reduces the variability introduced by using just one global climate model.

All of the available CMIP5 GCM historical simulations (table 1) were assessed on the basis of how well each model's simulated variables (for example rainfall, temperature) matched historical observations of the mean climatology over the tropical Pacific, annual climate cycle around islands near the monsoon trough (including Guam), and interannual teleconnections inferred from linear regressions of tropical Pacific-wide fields onto sea surface temperature (SST) anomalies in the Niño 3.4 region $\left(5^{\circ} \mathrm{N}-5^{\circ} \mathrm{S}, 170^{\circ} \mathrm{W}-120^{\circ} \mathrm{W}\right)$. All GCMs were ranked by their temporal and spatial correlations, root mean square errors, and Taylor skill scores (Taylor, 2001). Five well-performing GCMs were selected from this ranking (highlighted in red in table 1). Over the tropical Pacific, two basic climate variables considered for assessing model performance are SST and rainfall.

The models' ability to represent the western Pacific warm pool (regions where SST is greater than $27.5^{\circ} \mathrm{C}\left[81.5^{\circ} \mathrm{F}\right]$ ) as well as eastern Pacific cold tongue (regions where SST is less than $25^{\circ} \mathrm{C}\left[77^{\circ} \mathrm{F}\right]$ ) was examined (fig. 9). In the maps, the $27.5^{\circ} \mathrm{C}$ $\left[81.5^{\circ} \mathrm{F}\right]$ isotherm that illustrates the warm pool region is also shown. In the historical (1979-2005) simulations, the MME average of all $41 \mathrm{GCMs}$ and the five well-performing GCMs expresses the realistic spatial extent of the warm pool, although both categories show systematic biases in representing the eastern Pacific cold tongue where warm biases are noted. However, within the western Pacific warm pool, the models depict a slight cold bias, particularly near the equator. The amplitudes of the biases are 
smaller in the five well-performing models compared to a scenario where all 41 GCMs are considered.

\section{Projecting Future Typhoon Occurrence}

Typhoons threaten Guam with destructive winds, storm surges, high waves, and torrential rainfall. Water resources are also affected by substantial interannual variability of mean rainfall and typhoons. GCMs that capture the observed typhoon climatology and interannual variability associated with El Niño Southern Oscillation (ENSO), and for which notable biases in genesis location and storm tracks are identified, are used to assess future changes in typhoon occurrence. Forcing these models with increasing greenhousegas concentrations shows that only small changes in interannual variability are likely by the end of the twenty-first century, however the overall typhoon frequency decreases for most models.

The following, paraphrased from Widlansky and others (2018), is a discussion of the methods used to assess future typhoon changes. First, a climatology of tropical cyclone occurrence for the Pacific Ocean was produced using storm observations retrieved from the International Best Track Archive for Climate Stewardship (IBTrACS; Knapp and others, 2010). An objective tropical cyclone tracking algorithm (TRACK; Strachan and others, 2013) was then used on an atmospheric reanalysis (ERA-interim; Dee and Uppala, 2009), and the derived storm climatology was compared with the observed product from IBTrACS. This was repeated for CMIP5 (Taylor and others, 2012) historical and future climate projections using the five well-performing GCMs (table 1) and one higher-resolution atmosphere-only general circulation model (MRI-AGCM3.2) with a 20-kilometer (km; $12.4 \mathrm{mi})$ resolution to assess how atmospheric grid size affects the results (Widlansky and others, 2018).
Table 1. List of global climate models analyzed and used as input data for the regional climatic models.

[Models in red are the well-performing models selected for this study; model details available in Flato and others (2013)]

\begin{tabular}{ll}
\hline \multicolumn{1}{c}{ Global Climate Models } \\
\hline ACCESS1.0 & GISS-E2-H \\
ACCESS1.3 & GISS-E2-CC \\
BCC-CSM1.1 & GISS-E2-R \\
BCC-CSM1.1.M & GISS-E2-R-CC \\
BNU-ESM & HadCM3 \\
CanCM4 & HadGEM2-AO \\
CanESM2 & HadGEM2-CC \\
CCSM4 & HadGEM2-ES \\
CESM1-BGC & INM-CM4 \\
CESM1-CAM5 & ISPL-CM5A-LR \\
CMCC-CM & ISPL-CM5A-MR \\
CMCC-CMS & ISPL-CM5B-LR \\
CNRM-CM5 & MIROC4h \\
CSIRO-Mk3.6.0 & MIROC5 \\
EC-EARTH & MIROC-ESM \\
FGOALS-g2 & MIROC-ESM-CHEM \\
FIO-ESM & MPI-ESM-LR \\
GFDL-CM3 & MPI-ESM-MR \\
GFDL-ESM2G & MRI-CGCM3 \\
GFDL-ESM2M & NorESM1-M \\
& NorESM1-ME \\
\hline
\end{tabular}
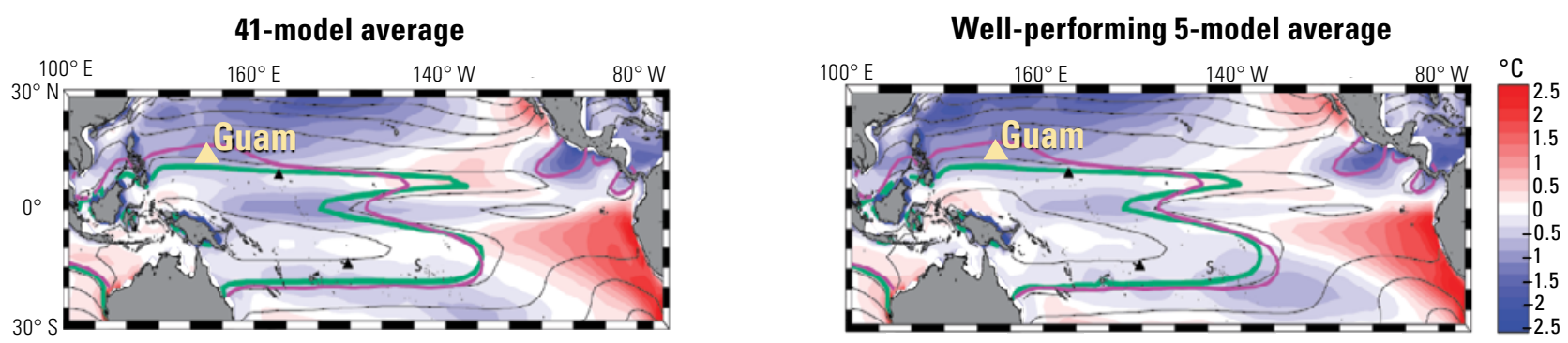

Figure 9. Maps displaying global climate model historical biases of sea-surface temperature. The average of a 41-model ensemble and 5 well-performing models are shown on the left and right, respectively. The observed and simulated warm pool (enclosed by the $27.5^{\circ} \mathrm{C}\left[81.5^{\circ} \mathrm{F}\right]$ contour) are indicated by the magenta and green lines, respectively. 


\section{Downscaling with Local Climate Models}

The local meteorology over Guam depends on the structure of the marine boundary layer and trade-wind inversion in the dry season and on the structure and location of the monsoon trough in the wet season, thus adequate simulation even in highresolution regional models is challenging to achieve. To produce meaningful results, coarse resolution GCMs are supplemented with much higher resolution local climate models (fig. 10). For this study, future-climate variables were produced through 20year simulations of a regional climate model with $20-\mathrm{km}$ (12.4mi) resolution covering the entire tropical western Pacific Ocean domain which was then downscaled successively twice (from $20 \mathrm{~km}$ to $4 \mathrm{~km}$ and then to $0.8 \mathrm{~km}$ [12.4 mi to $2.5 \mathrm{mi}$ to $0.5 \mathrm{mi}]$ ) culminating in a state-of-the-art, full-physics model with $0.8-\mathrm{km}$ (0.5-mi) spatial resolution encompassing the island of Guam (Zhang, 2016) (data available online at https://cida.usgs.gov/ thredds/catalog.html?dataset=cida.usgs.gov/guam).

The downscaled local model datasets have a gridded spatial resolution of 800 meters $(\mathrm{m} ; 0.5 \mathrm{mi})$, and temporal resolution of 1 hour. Variables from model datasets consist of: (1) data at the ground surface such as air pressure, upward heat flux, net shortwave radiation, and downward long-wave radiation, (2) data at $2 \mathrm{~m}(6.6 \mathrm{ft})$ above the ground surface such as air temperature and relative humidity, and (3) data at $10 \mathrm{~m}(33 \mathrm{ft})$ above ground surface such as wind speed.

\section{Estimating Future Sea Level}

Spatial datasets displaying Guam's shoreline at higher sea levels were downloaded from an interactive series of seawater inundation maps based on topography made available by the National Oceanic and Atmospheric Administration Office for Coastal Management (2017). By 2100, mean sea level around Guam is projected (17 percent probability) as high as $1 \mathrm{~m}$ (3.3 $\mathrm{ft}$ ) above present (2017) mean sea level and a small ( 0.3 percent) probability of being as much as $2 \mathrm{~m}(6.6 \mathrm{ft})$ higher (Sweet and others, 2017) (table 2). Even with sea level $2 \mathrm{~m}$ higher than present (2017), only about $2 \mathrm{~km}^{2}\left(0.8 \mathrm{mi}^{2}\right)(0.1$ percent $)$ of the present land surface in northern Guam would be inundated because of the island's steep near-shore topography. In northern Guam, seawater inundation is projected to extend inland by only a few tens of feet in most areas and up to several hundred feet in the low-lying Hagåtña Swamp (fig. 11). This low-lying area is likely to experience added inundation because groundwater levels may be up to $0.6 \mathrm{~m}(2 \mathrm{ft})$ above the projected mean sea level, but this added area of inundation was not considered substantial enough to warrant inclusion in this analysis.

\section{Estimating Future Streamflow}

To estimate future streamflow and future FVR water levels in southern Guam, future rainfall and air temperature inputs are needed for the PRMS_2016 and FVR_2016 models; a dataset of the historic and future input files is available

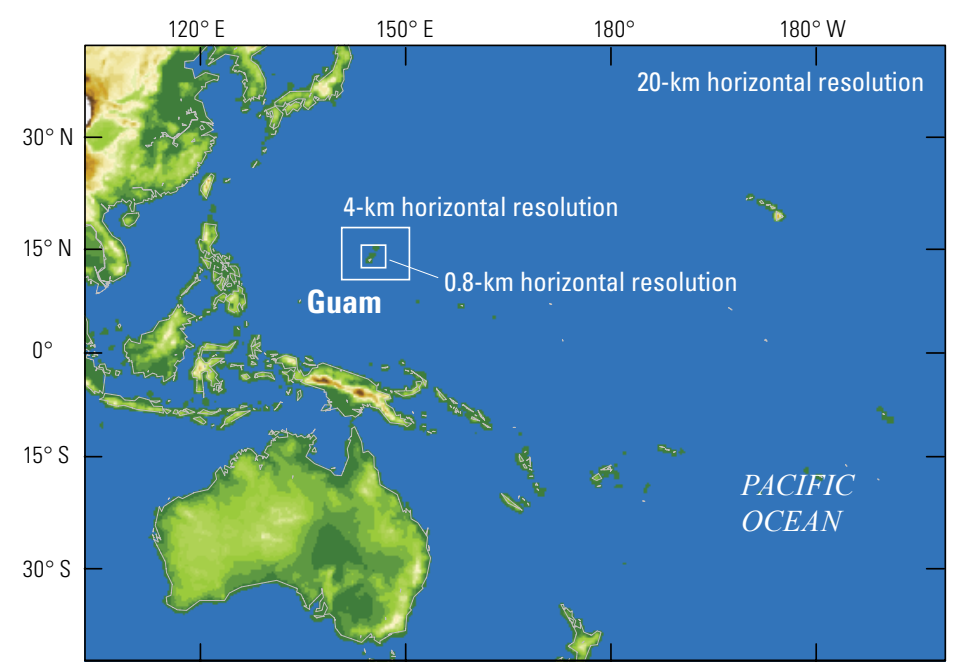

Figure 10. Colorized shaded relief map showing the design of the three-step approach of the regional model experiments. The horizontal resolution of the outer domain covering the entire tropical Pacific is about 20 kilometers $(\mathrm{km} ; 12.4 \mathrm{mi})$. The resolution of the domain covering Guam and its neighboring oceanic areas is $4 \mathrm{~km}(2.5 \mathrm{mi})$, and the resolution just over Guam is $0.8 \mathrm{~km}(0.5 \mathrm{mi})$.

Table 2. Probability of exceeding Global Mean Sea Level (median value) scenarios in 2100 for the Representative Concentration Pathway 8.5 warming scenario (from Sweet and others, 2017).

[GMSL, Global mean sea level; m, meter; ft, feet]

\begin{tabular}{lc}
\hline \multicolumn{1}{c}{ GMSL rise scenario } & $\begin{array}{c}\text { Probability of exceeding } \\
\text { GMSL, in percent }\end{array}$ \\
\hline Low $(0.3 \mathrm{~m} ; 1 \mathrm{ft})$ & 100 \\
Intermediate-Low $(0.5 \mathrm{~m} ; 1.6 \mathrm{ft})$ & 96 \\
Intermediate $(1.0 \mathrm{~m} ; 3.3 \mathrm{ft})$ & 17 \\
Intermediate-High $(1.5 \mathrm{~m} ; 4.9 \mathrm{ft})$ & 1.3 \\
High $(2.0 \mathrm{~m} ; 6.6 \mathrm{ft})$ & 0.3 \\
Extreme $(2.5 \mathrm{~m} ; 8.2 \mathrm{ft})$ & 0.1 \\
\hline
\end{tabular}

in Rosa, 2019 (https://doi.org/10.5066/P90S1CSX) and includes descriptions of how the data inputs were estimated. Future time series of rainfall and temperature were based on historic time series of Rosa and Hay (2017a and 2017b) modified by mean monthly change factors using methods described in Chase and others (2016). The computed change factors represent differences between projected temperature and rainfall for 2080-99 and for 1990-2009 (Zhang, 2016). Additive change factors computed the degree change in minimum and maximum air temperature at $2 \mathrm{~m}(6.6 \mathrm{ft})$ above the ground surface, and multiplicative change factors computed the fractional change for rainfall. Shortened historic and future 12-year periods (1998-2009 and 2088-99) of rainfall and temperature were used for the modeled regions 
in the Fena Valley Watershed (the Almagosa west, Almagosa, Imong, Maulap, and FVR_ungaged modeled regions in fig. 4) and the FVR because of missing climate station data before 1998 in the historic time series.

The PRMS_2016 model (Rosa and Hay, 2017b) computed future streamflow to the FVR under the future scenario (warming scenario RCP8.5) assuming no change in land cover. The streamflow estimates from the PRMS 2016 model simulations (Rosa, 2019) were input to the FVR_2016 water-balance model (Rosa and Hay, 2017b) to estimate FVR water levels at various water-withdrawal scenarios and to the FVR daily reservoir sedimentation model (Marineau and Wright, 2017) to estimate potential changes in the FVR storage capacity.

\section{Estimating Future Groundwater Recharge}

Spatially distributed estimates of mean annual recharge to the NGLA for recent (1990-2009) and future periods (2080-99), hereinafter "recent" and "future" recharge, were computed using the daily water-budget models described in Johnson (2012) and detailed in appendix 1. These periods were chosen to match the periods of recent and future climate projected by Zhang (2016). Previous recharge estimates for Guam from Johnson (2012) include those for a baseline (long-term historical average) scenario (1961-2005) and for a drought scenario, based on 1969-73 rainfall, for which mean annual recharge was estimated as 32 percent less than that for the baseline scenario (Gingerich, 2013). Although the baseline period was not used in the analyses for this study, a discussion of how it was estimated is included in appendix 1 for completeness. For the recent and future periods, the daily water-budget model and model inputs (soil and land-cover conditions, irrigation, septic leachate, and water-main leakage) were the same that Johnson (2012) previously used to compute recharge for the 1961-2005 period on Guam. Other model inputs (rainfall, runoff, and reference evapotranspiration) for the recent period were derived from historic records on Guam. For the future recharge, these three inputs were estimated from the future climate projections as detailed in appendix 1.

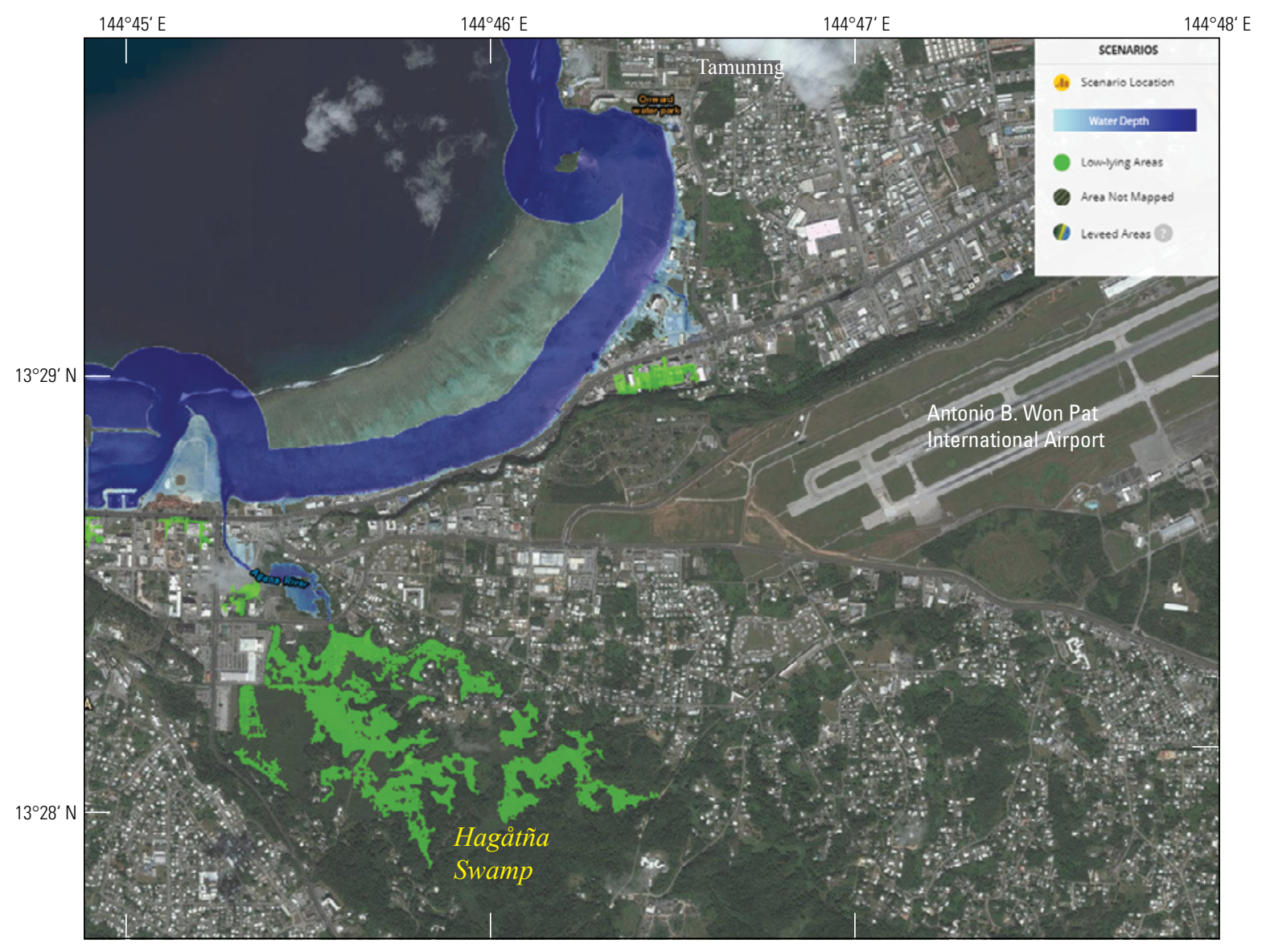

Figure 11. Example map image showing inundation near Hagåtña Swamp due to a hypothetical 1.8-meter [6-feet] rise in sea level around Guam (from National Oceanic and Atmospheric Administration Office for Coastal Management, 2017). (Water depth scale not provided by viewer website) 


\section{Estimating Future Groundwater Salinity}

An existing numerical groundwater model of the NGLA (Gingerich, 2013) was used to simulate freshwater-lens conditions in a future climate with lower recharge, higher sea level than present, and various groundwater withdrawal scenarios (model data files available in Gingerich, 2019). Guam's coastline, under sea-level-rise conditions evaluated, was reduced on the basis of island topography and modeled by increasing the number of onshore pressure nodes that represent the new and higher sea level in projected inundated areas. Additionally, the specified pressures of the offshore nodes were increased to represent the appropriate seawater depth. Simulations of future conditions (except those evaluating just an increase in sea level) used the spatially distributed estimate of mean annual recharge to the NGLA for 2080-2099.

Changes in simulated chloride concentrations at Guam's production wells were evaluated for the different model scenarios. As was described in Gingerich (2013), simulated equivalent chloride concentrations were converted from simulated salinity values in the SUTRA output by dividing the salinity value (expressed as a percentage of seawater) by 100 and multiplying the result by the assumed seawater chloride concentration $(19,600 \mathrm{mg} / \mathrm{L})$. Simulated salinity values are a flow-weighted average of all nodes representing the well. The volume-weighted chloride concentration of water produced from the entire set of production wells used in each scenario was calculated using:

$$
C_{\text {ave }}=\frac{\sum_{n=1}^{p w}\left(C_{n} \times R_{n}\right)}{\sum_{n=1}^{p w} R_{n}}
$$

where

$$
\begin{aligned}
& C_{\text {ave }} \quad \text { is the volume-weighted chloride concentration } \\
& \text { pw is the number of production wells, } \\
& C \text { is simulated chloride concentration at } \\
& \text { production well } n,[\mathrm{mg} / \mathrm{L}] \text {, and, } \\
& R \quad \text { is the withdrawal rate of production well } n \text {. } \\
& \text { [cubic liters per unit of time } \left.\left(\mathrm{L}^{3} / \mathrm{T}\right)\right]
\end{aligned}
$$

This volume-weighted chloride concentration (or composite concentration) represents an overall average concentration in which all the produced water is blended to create a uniform concentration for distribution. Individual production wells were also grouped into three categories: threatened ( $>500 \mathrm{mg} / \mathrm{L}$ chloride), cautionary $(200-500 \mathrm{mg} / \mathrm{L}$ chloride), or acceptable ( $<200 \mathrm{mg} / \mathrm{L}$ chloride) based on the simulated chloride concentration of pumped water (after Gingerich, 2013). Maps showing changes in simulated concentrations and concentration categories were compared to evaluate the model scenarios.

\section{Results and Discussion}

\section{Future Rainfall and Temperature}

Simulated rainfall across the western Pacific Ocean during the historical period (1979-2005) and future projections of rainfall change for 2069-89 can be compared for the five well-performing GCMs (fig. 12). The results for boreal summer (June through August) season are shown in the left panel and those for the winter (December through February) season are shown in the right panel. In contrast to SST projections, where the entire tropical Pacific Ocean region is expected to experience increased temperature, rainfall projections indicate a mixed response. During summer and winter seasons, the CMIP5 GCMs project an overall increase in rainfall this century along the equatorial and tropical northwestern regions of the Pacific Ocean near Guam. The projected rainfall increase is larger during the summer (wet) season. During future winter (dry) seasons, the projection shows a narrow east-west stretching zonal band of decreased rainfall that extends from south of Guam to the equator.

Based on modeled rainfall estimates from the RCP8.5 scenario for Guam (Zhang, 2016), Guam's annual rainfall in a future climate (2080-99) is projected to be about 94 percent of recent (1990-2009) rainfall (fig. 13A). Drought-like conditions (defined here as more than 20 percent below mean annual historic rainfall) will occur more frequently. Records of rainfall measured at the Antonio B. Won Pat International Airport (fig. 1) (available at https://www.ncdc.noaa.gov) indicate that, during a recent 50-year period (1966-2015), annual rainfall was more than 20 percent below recent (1990-2009) rainfall only 16 percent of the time. In comparison, future rainfall that is based on downscaled climate models, will be at least 20 percent below recent rainfall 40 percent of the time. In other words, Guam is projected to experience drought-like rainfall conditions 4 years out of every 10, whereas historically, drought-like conditions occurred about 1.6 years out of every 10 .

Future rainfall projections indicate a decline (relative to 1990-2009 observed conditions) in overall rainfall of about 7 percent in the modeled regions of southern Guam (Rosa and Hay, 2017a). Rainfall decreases by about 12 percent during the wet season (July through December) and increases by about 9 percent during the dry season (January through June). Future temperature projections indicate an average $3.2^{\circ} \mathrm{C}\left(5.8^{\circ} \mathrm{F}\right)$ increase in daily temperature for the collective area of the modeled regions in southern Guam. As a result, about 2.4 times as many days in the future-climate scenarios will have average maximum air temperatures over $32.2^{\circ} \mathrm{C}$ $\left(90^{\circ} \mathrm{F}\right)$ in the modeled regions of southern Guam (Rosa and Hay, 2017a). In the twelve years of modeled future climate (the shortened period modeled because of missing data), the number of days over $32.2^{\circ} \mathrm{C}\left(90^{\circ} \mathrm{F}\right)$ increased in the range of 115-257 days per year depending on the years modeled. 

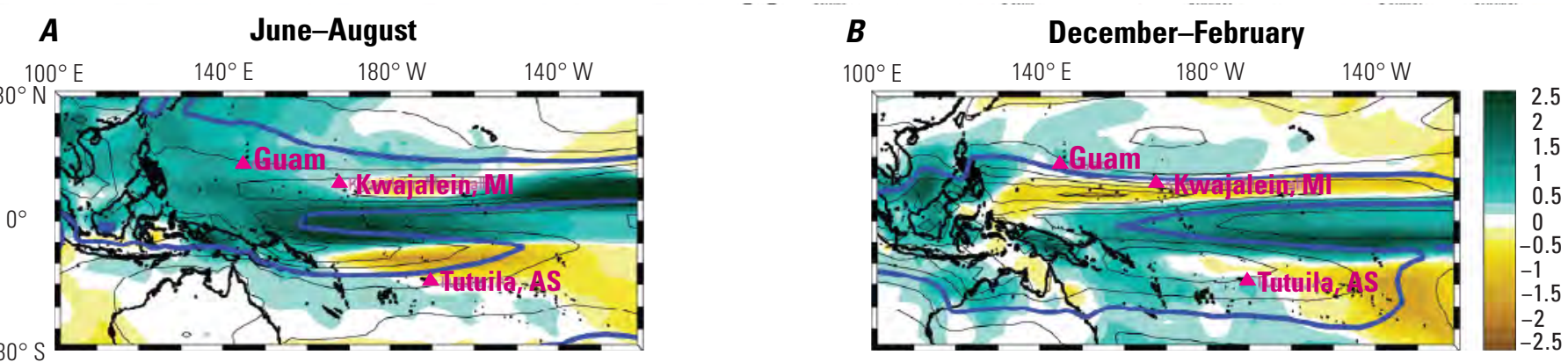

Figure 12. Maps showing the change of seasonal average daily rainfall rates between the historical period and future scenario using the top five well-performing global climate model multimodel ensemble (MME) averages. $(A)$ Rainfall difference in the boreal summer during 2069-2089 under scenario Representative Concentration Pathway (RCP) 8.5 compared to 1979-2005. (B) Rainfall difference in the boreal winter during 2069-2089 under scenario RCP8.5 compared to 1979-2005. The blue lines denote the major historical rainfall bands (values greater than 5 millimeters per day).

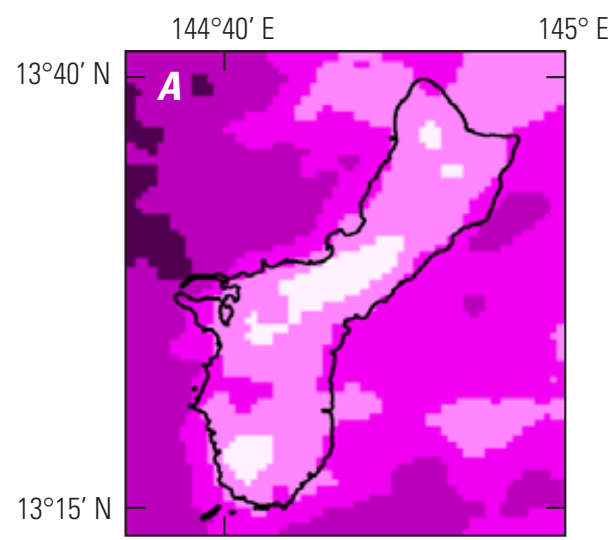

Simulated change in rainfall, in percent

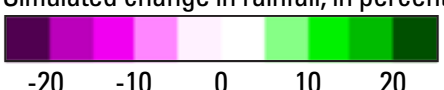

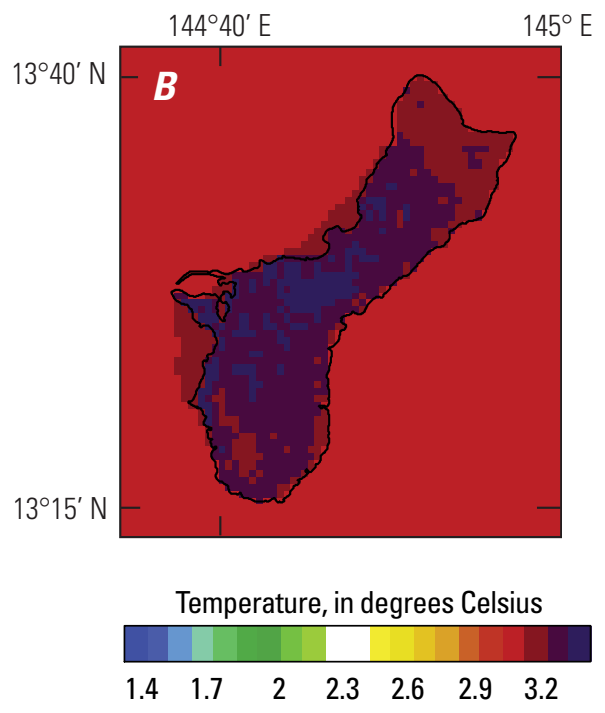

Figure 13. Maps showing simulated change in $(A)$ rainfall (in percent) and $(B)$ temperature (in degrees Celsius) during 2080-99 under scenario Representative Concentration Pathway (RCP) 8.5 compared to 1990-2009.

Projections of future-climate variables using the downscaled local climate model show an overall decrease in rainfall amounts, whereas the CMIP5 GCM results indicate a wetter climate for the region. However, downscaled local climate model results showing drier conditions were used in this study to project future streamflow and recharge conditions and are considered more reliable because local orographic conditions for Guam are included in the analysis.
Tropical cyclone genesis counts (per year) are similar between historical data, also referred to as reanalysis products, (78 observed storms; fig. 14A) and high-resolution atmospheric model integration (72 simulated storms; fig. 14B). Similarly, the tropical cyclone track assessed from the objective algorithm indicates that the high-resolution model captures the overall tracks obtained from the reanalysis products (fig. 14C and 14D). 

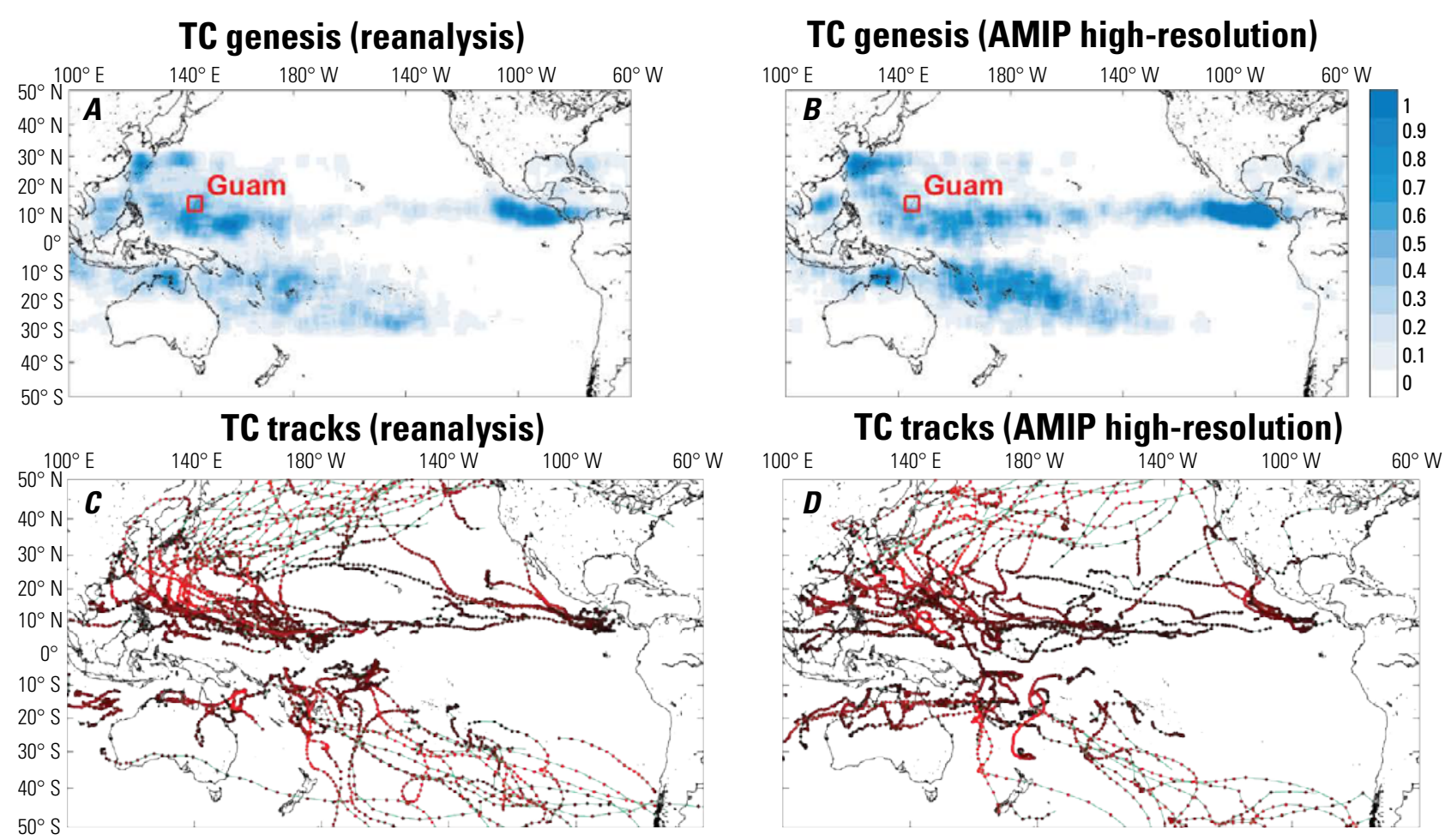

Figure 14. Maps showing tropical cyclone $(\mathrm{TC})$ genesis density $(A, B)$ and tracks $(C, D)$ determined by an objective assessment of simulated storms in the ERA-interim reanalysis (78 storms; $C$ ) and a high-resolution atmospheric model prescribed with observed sea-surface temperature (SST) (72 storms; D). Stronger storms are indicated by brighter red locations, as inferred from atmospheric vorticity. The ERA-interim reanalysis is described in Dee and Uppala (2009). [AMIP, Atmospheric Model Intercomparison Project].

From these analyses, the TRACK algorithm successfully detects tropical cyclones in the reanalysis and climate models, although there are biases in CMIP5, such as too many tropical storms in the central Pacific Ocean and not enough typhoons in the northwestern Pacific Ocean (for example near Guam). To address such spatially dependent biases, climate-change projections are presented either as the difference between future and historical simulations or by scaling the occurrence of tropical cyclones around island regions so that the mean of the historical period matches that of observations (Widlansky and others, 2018). Furthermore, for all future change analyses, the signal-to-noise ratio was maximized by considering the high future greenhouse-gas concentration scenario (RCP8.5) and also by calculating the multimodel mean. Greenhouse warming produces an overall decrease this century in the number of tropical storms and typhoons likely affecting Guam (20-30 percent decrease; multimodel average; Widlansky and others, 2018) (fig. 15), although year-to-year variability in storm occurrence is projected to continue with variations in the tropical circulation and atmospheric moisture necessary for tropical cyclone genesis (Camargo and others, 2007; Gray, 1979). However, an above-average typhoon year in the future will still be more active than the historical average.

No significant increase in the interannual occurrence of tropical cyclones by the end of the 21 st century was found (fig. 15); in fact, the range of likely number of storms decreased slightly for Guam (Widlansky and others, 2018). A possibility of enhanced ENSO-related tropical cyclone interannual variability remains, because some climate-change experiments suggest that the atmospheric environment during future El Niño events will be more conducive for storm genesis (Chand and others, 2017). Yet, at least for the models considered, any future increases in year-to-year variability seem to be overwhelmed by mean state changes (less tropical cyclones).

Averaging over future years, in contrast, Widlansky and others (2018) found pronounced long-term changes that are mostly consistent with other studies. The majority of the most realistic climate models from CMIP5 project that the overall tropical cyclone occurrence southeast of Guam will decrease with greenhouse warming (fig. 16A) as less moisture rises to the layer of the atmosphere where convection is strongest. Decreased tropical cyclone numbers are likely a manifestation of the expected future weakening of tropical circulation (Knutson and others, 2010).

Although decreased numbers of tropical cyclones are projected, the same models project that the tropical cyclones that occur are likely to be stronger, especially in the northcentral Pacific Ocean where directly simulated maximum intensity also increases (fig. 16B). This is because higher SSTs provide more thermodynamic energy to convert to wind (Emanuel, 1999). 


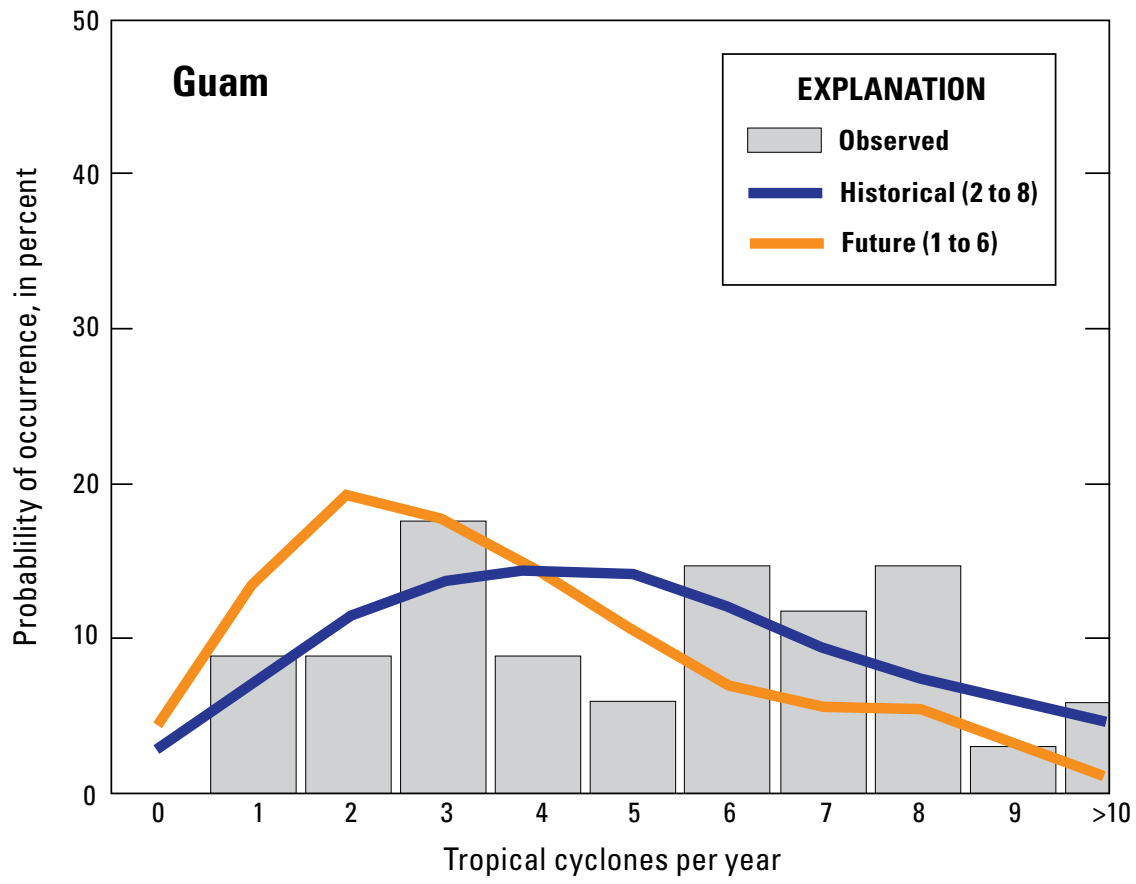

Figure 15. Chart displaying the probability of tropical cyclone occurrence for observations (1979-2012; gray bars), simulations of the historical period (1976-2005; blue line), and the future (RCP8.5; orange line) climate with greenhouse warming (2071-2100) around Guam (modified from Widlansky and others, 2018). Shown is the multimodel average of simulations from five well-performing CMIP5 models and one higher-resolution atmospheric model. The range of storm counts expected during about 68 percent of years is in parentheses $( \pm 1$ standard deviation from the mean). Simulations are scaled to remove model biases in storm genesis and tracks.
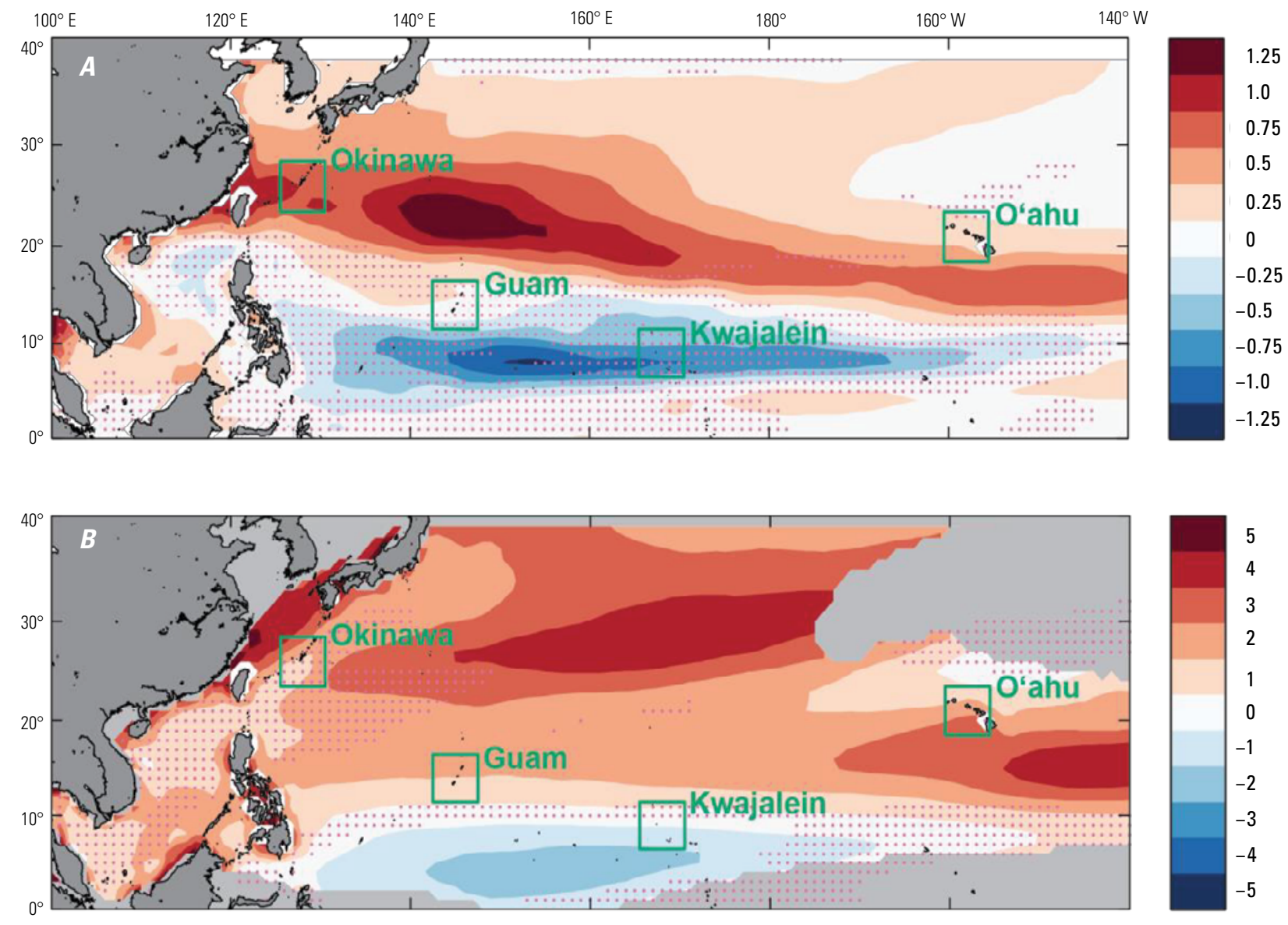

Figure 16. Regional maps showing projected change (2071-2100 minus 1976-2005) in (A) simulated tropical cyclone genesis potential; $(B)$ Maximum potential intensity change (modified from Widlansky and others [2018]). The projected change is calculated from historical and future (Representative Concentration Pathway 8.5) climate simulations of sea-surface temperature and pressure. The multimodel average from five well-performing climate models is shown. Stippling indicates where less than four out of five models agree on the sign of future change. 
The decrease in the mean number of tropical cyclones projected to affect Guam with continued greenhouse warming is consistent with expected future weakening of the tropical circulation and a decrease globally in the number of storms forming (Christensen and others, 2013). Less vertical lift and a drying middle part of the troposphere, which has been shown to limit tropical cyclone genesis (Knutson and others, 2010), are noted in the future-climate model simulations. Whereas future higher SST and a more unstable atmosphere are consistent with more intense typhoons (for example Emanuel, 1995), future intensity changes cannot be directly assessed using coarseresolution (greater than $100 \mathrm{~km}$ [62 mi]) GCMs because they do not simulate well the strongest typhoons.

\section{Projected Impacts on Surface-Water Resources}

\section{Streamflow Under Future Conditions}

Streamflow is projected, for the twelve modeled regions, to decrease by 12 to 36 percent in a future climate relative to streamflow in the historic period as modeled by the PRMS_2016 model. FVR modeled regions compare the years 1998-2009 with 2088-99, and all other modeled regions compare the years 1990-2009 with 2080-99. Projected streamflow declines in the individual HRUs range from 2 to 78 percent (fig. 17); PRMS_2016 estimates that for the domain of the PRMS_2016 model, total streamflow for the time periods evaluated will be about 18 percent less. Streamflow decreases are due to decreased future rainfall and increased actual evapotranspiration. Increases in future minimum and maximum temperatures will cause as much as a 29-percent increase in actual evapotranspiration in the modeled regions.

\section{Fena Valley Reservoir Storage Under Future Conditions}

Future FVR water levels were estimated on the basis of future climate conditions for a range of constant water-withdrawal rates (5.0 to $11.0 \mathrm{Mgal} / \mathrm{d}$ ) using multiple FVR_2016 model simulations (table 3; fig. 18). The withdrawal rates simulated are about 1 to 2 times the average withdrawal rate $(5.5 \mathrm{Mgal} / \mathrm{d})$ during 2010-14 and cover the range of water-supply rates used to meet demand in the area that receives FVR water. This time period represents the last five years of accessible withdrawal data and is the most representative time period to summarize recent demand. Expected future demand is unknown, but the pumping range evaluated in the scenarios is greater than any expected potential increase. These simulations assume constant reservoir storage capacity to apply the reservoir stage-storage capacity curves (Marineau and Wright, 2015) in the FVR_2016 model and assume that the initial water level of the reservoir was at capacity. The simulated FVR water levels are compared with conservation levels $\mathrm{I}$ to $\mathrm{V}$ where level $\mathrm{I}$ is the most restrictive and level $\mathrm{V}$ is the least restrictive (Naval Base Guam, 2012).

Table 3. Percentage of time monthly reservoir water levels are below or within each of the Fena Valley Reservoir water-conservation levels for selected water-withdrawal rates and climate conditions.

[Historic climate refers to 1998-2009, future climate refers to 2080-99 under scenario Representative Concentration Pathway 8.5]

\begin{tabular}{|c|c|c|c|c|c|}
\hline \multirow{2}{*}{$\begin{array}{c}\text { Percentage of time monthly reservoir water } \\
\text { levels are within conservation levels for } \\
\text { the indicated withdrawal rate, in million } \\
\text { gallons per day }\end{array}$} & \multicolumn{5}{|c|}{ Conservation level ${ }^{1}$} \\
\hline & $\mathbf{v}$ & IV & III & II & I \\
\hline \multicolumn{6}{|c|}{12 years of historic climate } \\
\hline 5 & 100 & 0 & 0 & 0 & 0 \\
\hline 7 & 100 & 3 & 1 & 0 & 0 \\
\hline 9 & 100 & 22 & 3 & 0 & 0 \\
\hline 11 & 100 & 46 & 17 & 3 & 0 \\
\hline \multicolumn{6}{|c|}{12 years of future climate } \\
\hline 5 & 100 & 1 & 0 & 0 & 0 \\
\hline 7 & 100 & 6 & 3 & 0 & 0 \\
\hline 9 & 100 & 38 & 8 & 1 & 0 \\
\hline 11 & 100 & 67 & 41 & 15 & 1 \\
\hline \multicolumn{6}{|c|}{2 years of future drought ${ }^{2}$} \\
\hline 5 & 100 & 8 & 0 & 0 & 0 \\
\hline 7 & 100 & 25 & 17 & 0 & 0 \\
\hline 9 & 100 & 83 & 42 & 8 & 0 \\
\hline 11 & 100 & 96 & 83 & 58 & 17 \\
\hline
\end{tabular}

${ }^{1}$ Conservation levels $\mathrm{V}$ to I refer to five ranges, from least (V) to most (I) restrictive, in reservoir water levels used by managers to convey water availability and conservation measures (Naval Base Guam, 2012)

${ }^{2}$ Watershed model inputs to the reservoir water-balance model for the driest year within the future climate scenario modeled (2088) were used for 2 years back-to-back to simulate an extended period of drought 


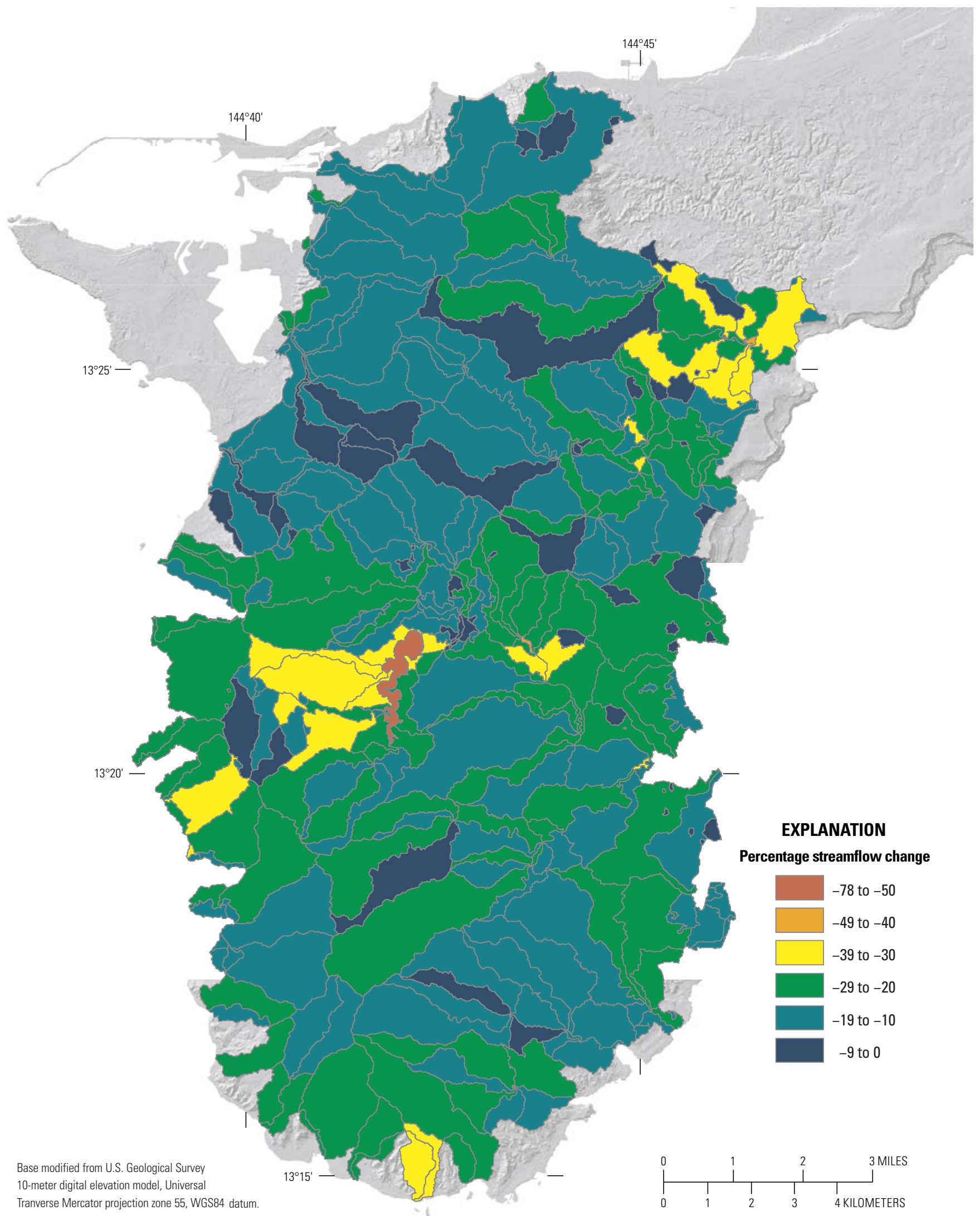

Figure 17. Map of southern Guam showing percentage streamflow change by hydrologic response unit (HRU) in the PRMS_2016 model for the scenario Representative Concentration Pathway 8.5. Fena Valley Reservoir modeled regions compare the years 1998-2009 with 2088-2099 and all other modeled regions compare the years 1990-2009 with 2080-2099. 
EXPLANATION

Conservation level

Figure 18. Bar chart table showing percentage of time monthly reservoir water levels are below or within each of the Fena Valley Reservoir water-conservation levels for selected water-withdrawal rates. The future scenario is for Representative Concentration Pathway 8.5, 2080-99.

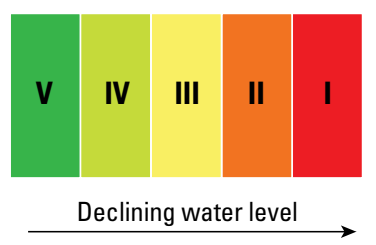

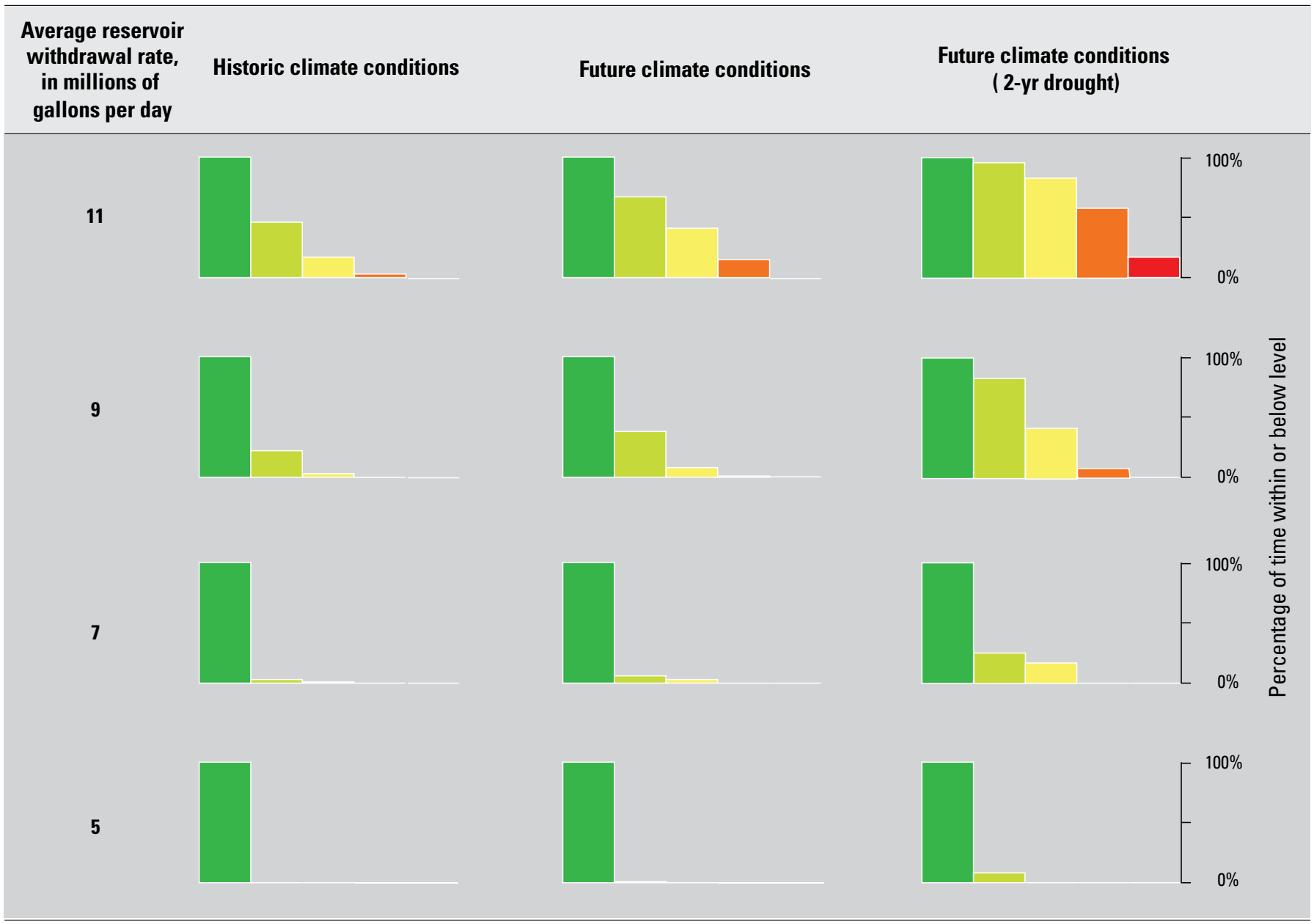

Results indicate that under future climate conditions, FVR water levels remain in level $\mathrm{V}$ most of the time at the lowest rate (5 Mgal/d) but fall into level IV for one month during the 12-year simulation. At the highest rate (11 Mgal/d), FVR water levels fall into level IV 67 percent of the time, into level III 41 percent of the time, and into level II 15 percent of the time (table 3; fig. 18). Although the FVR water levels fall into level I for one month, they always remain at least $12.5 \mathrm{ft}$ above the level of the pump intakes. In comparison, simulations for the historic (1998-2009) climate period and the lowest withdrawal rate indicate that FVR water levels remain at level $\mathrm{V}$ for the entire simulation. At the highest rate, FVR water levels fall into level IV 46 percent of the time, into level III 17 percent of the time, and into level II 3 percent of the time (table 3; fig. 18). For the lowest withdrawal rate considered (which is most similar to the 2010-14 withdrawal rate of $5.5 \mathrm{Mgal} / \mathrm{d}$ ), model results indicate that FVR water levels are in level IV for one month more during future conditions relative to historic conditions. A trial-and-error procedure using the FVR_2016 model indicated that a maximum withdrawal rate of 11.4 Mgal/d would maintain water levels above the pump intake elevation (shown as $45 \mathrm{ft}$ below the dam spillway in Kennedy Engineers, Inc., 1974) for 12 years of the future climate conditions.

Two-year drought simulations were run using the minimum annual rainfall from the 12-year future climate (year 2088) for two years back-to-back to simulate an extended period of drought and a range of water-withdrawal rates. At sustained water-withdrawal rates less than $9 \mathrm{Mgal} / \mathrm{d}$, progressively more serious conservation levels are reached, but the reservoir still recovers after the dry 
season with water levels returning to the elevation of the spillway at the end of the two-year drought (table 3; fig. 18). However, simulating sustained pumping at the highest water-withdrawal rate $(11 \mathrm{Mgal} / \mathrm{d})$ during the projected two-year drought shows that the reservoir will not recover after the dry season and the water level decreases to the elevation of the pump intake after 20 months in the 24-month period simulated.

\section{Fena Valley Reservoir Sedimentation Under Future Conditions}

Results of FVR-sedimentation-model simulations, using future streamflow conditions for the FVR, indicate that the future sediment load discharged into the reservoir will decrease by about 32 percent relative to the modeled sediment load for the historic period because of the decrease in streamflow. At this estimated future sediment load, the reservoir will lose about 0.46 percent/yr of its storage capacity in the future compared with 0.68 percent/ yr during 1951-2014. However, because historically about 81 percent of the total sediment load to the FVR was generated from the five largest daily streamflow events (Marineau and Wright, 2017); the future sedimentation rate depends on the occurrence of the rarest but most intense storms. The projection of less frequent but stronger tropical cyclones near Guam for the RCP 8.5 scenario (Widlansky and others, 2018) would suggest that the sediment load discharged into the FVR could increase due to the increased intensity of these rare storms. Currently available climate models of future conditions are not able to accurately predict rainfall intensity for any particular storm; therefore, accurately quantifying how future typhoons could increase the sedimentation rates is not possible.

\section{Mitigation Strategies for Increasing Future Surface-Water Availability}

Several possible strategies that increase FVR water availability in a future climate with less stream discharge into FVR were evaluated by applying the 2088-99 streamflow estimates from the PRMS_2016 model. The simulations described herein provide insight into the effectiveness of these mitigation strategies, in terms of increasing available and accessible water in FVR, but do not consider several other variables (for example, cost, engineering feasibility, environmental impact, reduced capacity due to future sedimentation) that must be considered before adopting these strategies. The mitigation strategies investigated are: (1) lowering the FVR water-supply intake elevation, (2) increasing storage capacity by increasing the height of the FVR spillway, and (3) a combination of (1) and (2).

\section{Lowering Fena Valley Reservoir Water-Supply Intake Elevation}

This mitigation strategy involves lowering the elevation of the FVR water-supply intakes to increase the usable volume of water available from the reservoir. A simulation in which the FVR_2016 model input file was modified to represent the intake elevation being lowered by $5 \mathrm{ft}$ to a new elevation of $50 \mathrm{ft}$ below the spillway elevation was completed. For this simulation, a constant withdrawal rate of $11.6 \mathrm{Mgal} / \mathrm{d}$ could be maintained during 12 years of the future climate conditions without lowering the water level to the water-supply intake during any of the driest periods. This results in an increased withdrawal rate of 1.7 percent compared to a simulation with future climate and the existing intake configuration.

\section{Increasing Fena Valley Reservoir Spillway Height}

This mitigation strategy involves increasing the FVR spillway elevation to increase the volume of water impounded in the reservoir. Kennedy Engineers, Inc. (1974) investigated the possibility of increasing the spillway height by as much as $40 \mathrm{ft}$ but only considered the implications to the dam infrastructure and did not estimate the increased reservoir capacity. Estimates of increased FVR capacity for a 5-ft spillway elevation increase, using an extension of the 2015 stage capacity curve (Marineau and Wright, 2015) and a 2013 aerial Light Detection and Range (LiDAR) survey (U.S. Geological Survey and others, 2015) to estimate the topography above the spillway elevation around the reservoir, indicate that capacity increases of 14-15 percent could be expected (see appendix 2). The extended stage capacity curve (appendix 2) was also incorporated into the FVR_2016 model to simulate increasing the FVR spillway elevation by $5 \mathrm{ft}$. FVR_2016 model simulations indicate that a constant withdrawal rate of $11.8 \mathrm{Mgal} / \mathrm{d}$ could be maintained during 12 years of the future climate conditions without lowering the water level to the water-supply intake during any of the driest periods. This results in an increased withdrawal rate of 3.5 percent compared to a simulation with future climate and the existing spillway configuration. The relatively small increase in available withdrawal despite the larger increase in reservoir capacity is because the amount of streamflow during each year of the 12-year simulation is not sufficient to fill the reservoir to the added capacity gained by raising the spillway. Therefore, the total annual withdrawal rate is limited not by the capacity of the reservoir, but by the projected amount of streamflow available to fill the reservoir.

\section{Lowering FVR Water-Supply Intake Elevation and Increasing FVR Spillway Height}

This strategy is a combination of the previous two strategies; lowering the intake elevation by $5 \mathrm{ft}$ and increasing the spillway height by $5 \mathrm{ft}$. FVR_2016 model simulations indicate that a constant withdrawal rate of $12 \mathrm{Mgal} / \mathrm{d}$ could be maintained during 12 years of the future climate conditions without lowering the water level to the water-supply intake during any of the driest periods. This results in an increased withdrawal rate of 5.3 percent compared to a simulation with future climate and the existing intake and spillway configuration. 


\section{Projected Impacts on Groundwater Resources}

Mean annual island-wide recharge for the future (2080 99) period was estimated to be $335 \mathrm{Mgal} / \mathrm{d}$, or 15 percent less (394 Mgal/d) than that estimated for the 1961-2005 and the 1990-2009 periods (Johnson, 2012). For just the part of the island underlain by the NGLA, mean annual recharge for the future period was estimated to be $193 \mathrm{Mgal} / \mathrm{d}$, also 15 percent less than that estimated for the 1990-2009 period, and 19 percent less than that estimated by Johnson (2012) for the 1961-2005 period (fig. 19). These recharge volumes translate to $39 \mathrm{in} / \mathrm{yr}$ and $47 \mathrm{in} / \mathrm{yr}$ for the 2080-99 future period and the 1990-2009 period, respectively. Input datasets of future climate that were used in making these estimates were released by Johnson (2019).

Future recharge to the NGLA is estimated to be highest during the wet season (July through December) when rainfall is highest (fig. 20). This pattern is expected to remain the same as the 2012 annual recharge distribution. Recent analysis of stable isotopes in rain, vadose cave drip water, and groundwater collected on Guam, in part, for this study, provides evidence that most recharge reaches the NGLA from rain falling during the wet season (Beal and others, 2019). The $\delta^{18} \mathrm{O}$ value of rainwater is lighter during the rainy season (fig. $21 \mathrm{~A}$ ) and in a plot of the $\delta^{18} \mathrm{O} / \delta \mathrm{D}$ value in the collected samples, the groundwater samples plot near the wet season rainfall samples (fig. $21 B$ ) indicating a similar source. Water samples were collected at several locations in northern Guam (fig. 1); rainfall at the University of Guam campus, vadose cave drip water in Jinapsan Cave, and groundwater from selected production wells in the NGLA during 2008-2015 (locations shown in Beal and others, 2019).

The effects of the projected 19-percent decrease in recharge and increased sea level on groundwater resources were evaluated through several simulation scenarios. The withdrawal distributions simulated consist of the 2010 distribution (for comparison with scenarios in Gingerich, 2013), a projected future demand distribution with improved production-well concentrations (Scenario 5 of Gingerich, 2013), and several modified versions of the projected future demand distribution in which well depths and withdrawal rates were modified to reduce the chloride concentration of the withdrawn water. All simulations were continued to steady-state (no significant changes in water levels or concentration), except for a drought scenario. The drought scenario was continued for two years starting from the steady-state condition having $3.3 \mathrm{ft}$ of increased sea level and future average recharge.

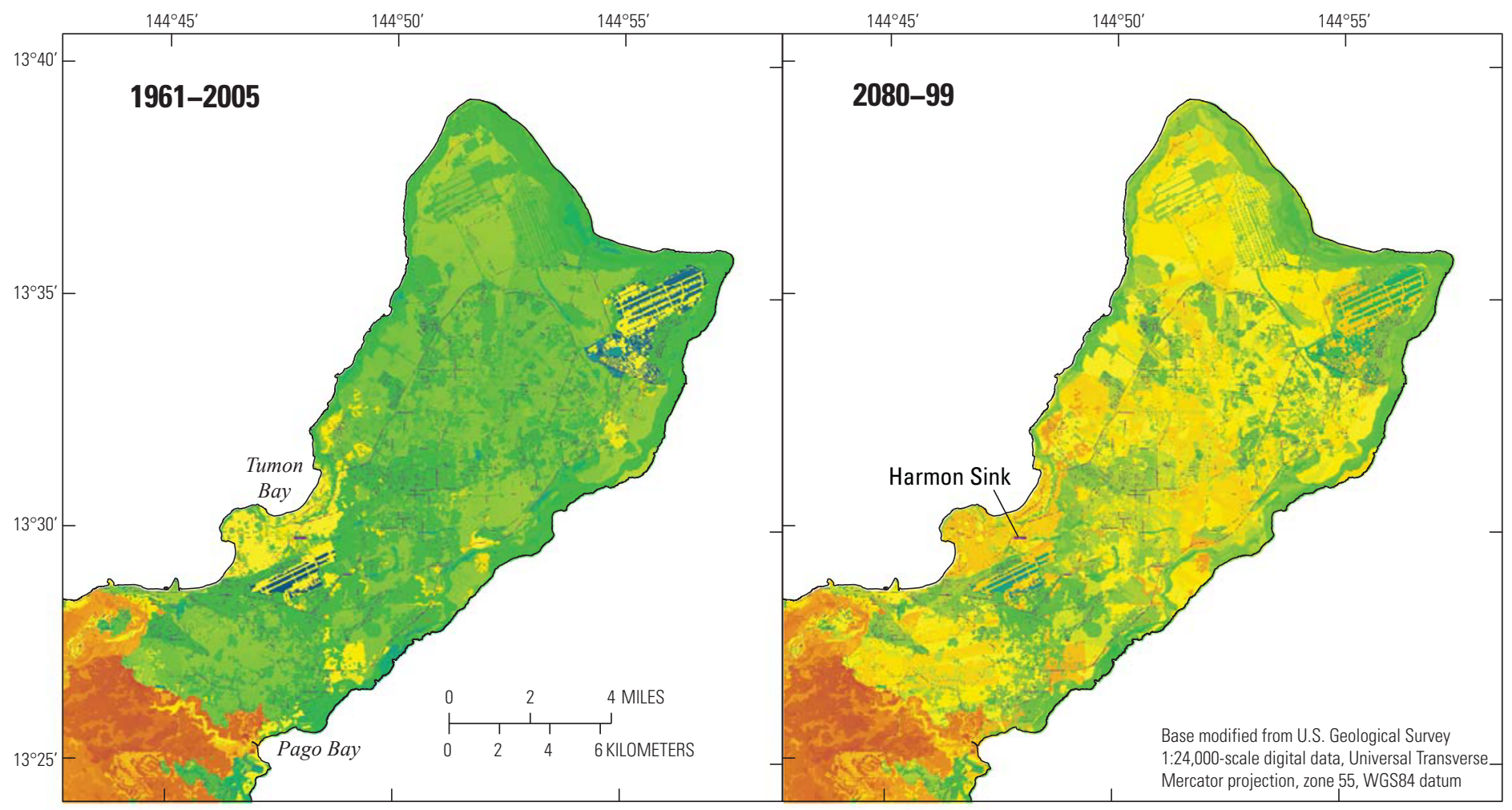

Mean annual recharge, in inches

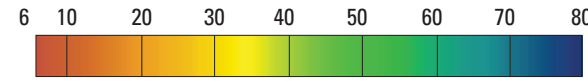

\section{EXPLANATION}

Areas where mean annual recharge is between 80 and 769 inchesincludes areas with water-main leakage, septic leachate, and the Harmon Sink (a stormwater-discharge basin)

Figure 19. Maps showing the distribution of mean annual groundwater recharge estimated for the Northern Guam Lens Aquifer for historic (1961-2005) climate conditions (modified from Johnson, 2012) and future (scenario Representative Concentration Pathway 8.5, 2080-99) climate conditions. 


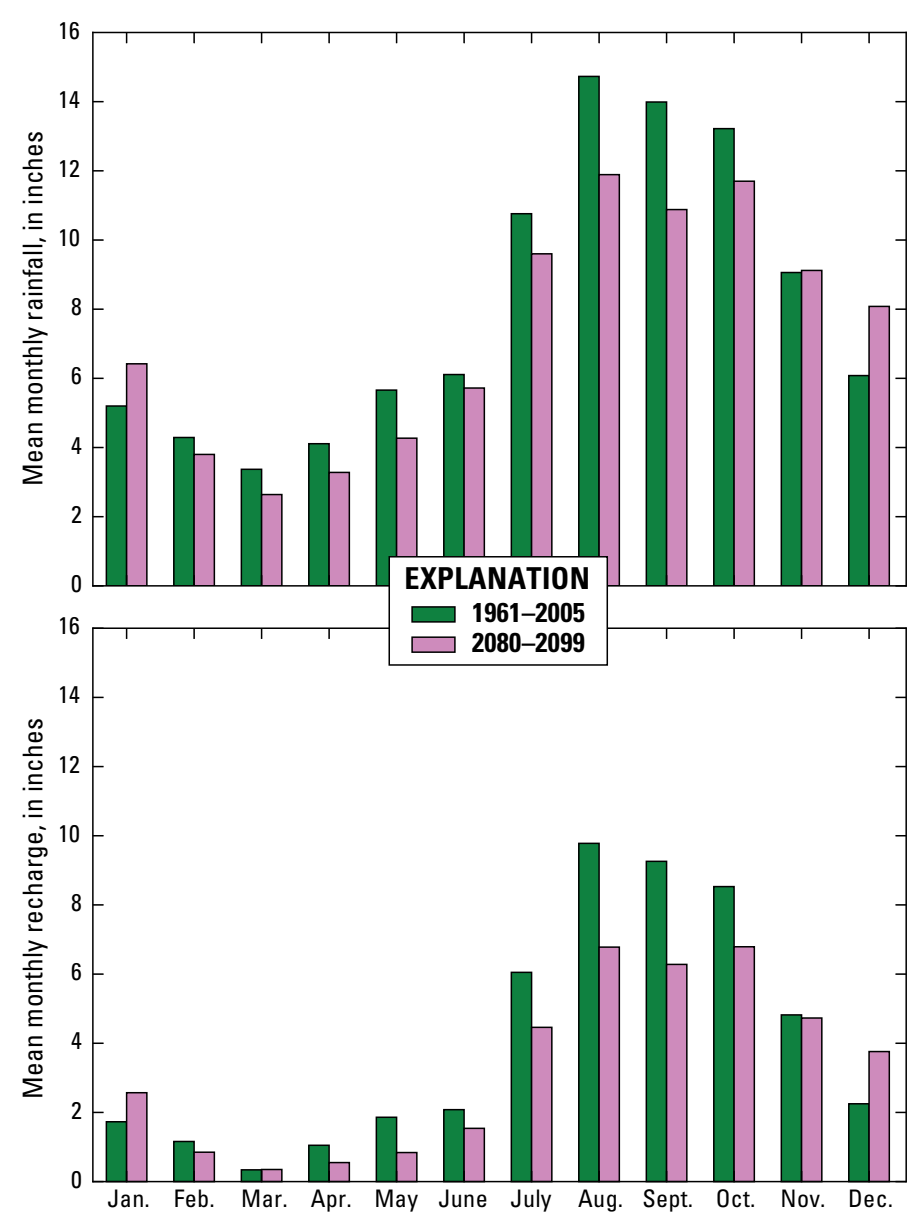

Figure 20. Graphs showing estimated mean monthly rainfall, artificial inflow (irrigation, water-main leakage, and septic-system leachate), total evapotranspiration, and recharge, future conditions (scenario Representative Concentration Pathway 8.5, 2080-99) for the northern aquifer sectors of Guam defined by Mink (1991).

\section{Groundwater Conditions with Increased Sea Level}

Under the 2010 withdrawal distribution, historic recharge, and a sea-level increase of $6.6 \mathrm{ft}$, the model simulation indicates a small impact on the chloride concentration of water pumped from the production wells in the NGLA. The composite concentration for all the production wells is about $130 \mathrm{mg} / \mathrm{l}$, which is only slightly higher than the composite concentration of $126 \mathrm{mg} / \mathrm{L}$ for a similar simulation of recent sea-level conditions (Gingerich, 2013). The numbers of production wells operating under the "threatened" and "cautioned" categories are nearly unchanged with a 6.6-ft increase in sea level although one production well is shifted into a higher concentration category (fig. 22A). Thus, the 6.6-ft sea-level rise condition alone is not expected to be a vital factor in increasing salinity from the production-well system. Wells impacted the most by increased sea level are those completed deeper into the aquifer and with open intervals closer to the transition zone between freshwater and saltwater in the aquifer. As the freshwater lens is elevated $6.6 \mathrm{ft}$ by the increased
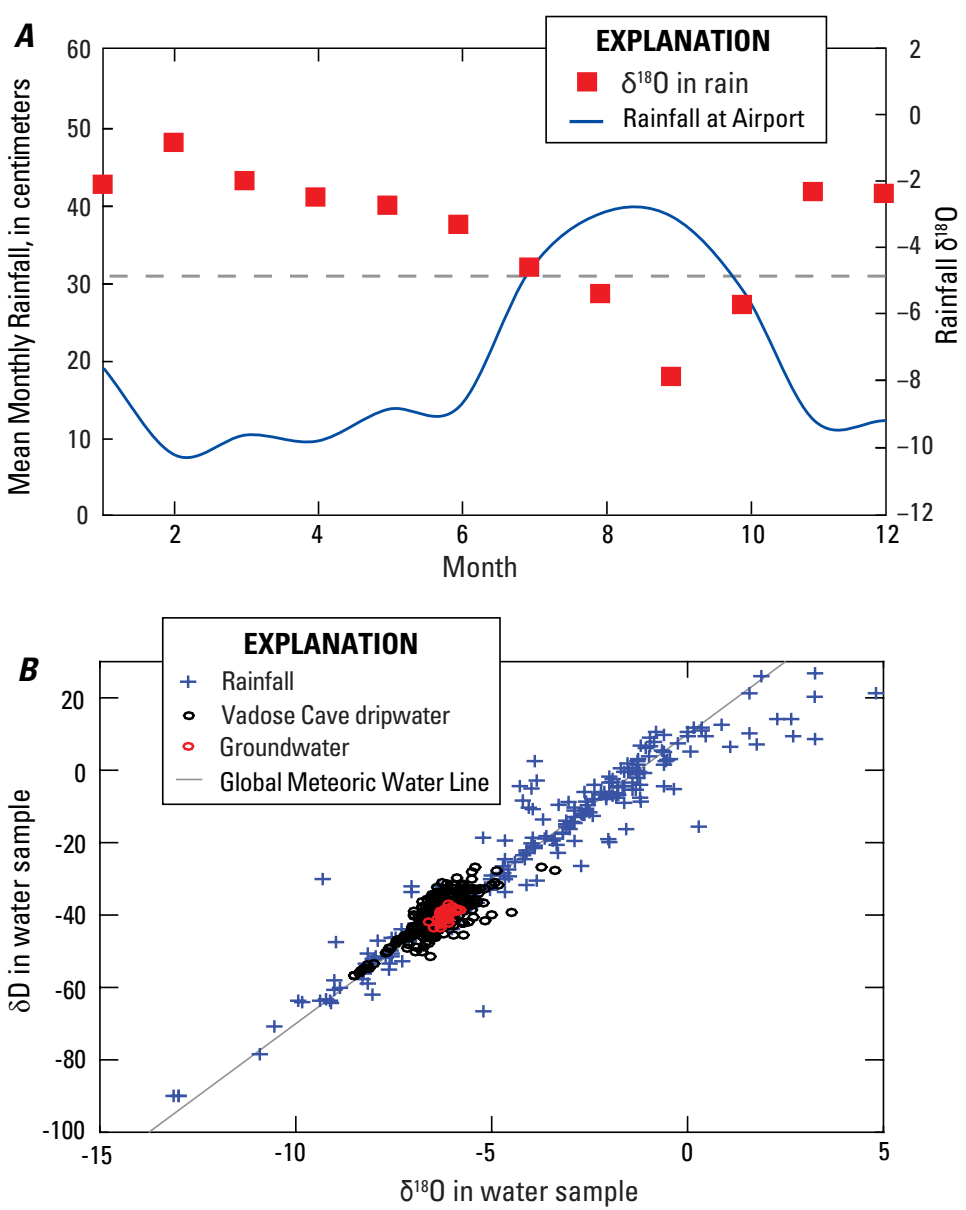

Figure 21. Graphs showing stable isotope values in water samples from Guam. (A) Monthly measurements of rainfall (at A. B. Won Pat International Airport) and $\delta^{18} \mathrm{O}$ in rainwater (collected at University of Guam campus). (B) $\delta^{18} \mathrm{O} / \delta \mathrm{D}$ ratios in rainfall (collected at University of Guam campus), vadose cave drip water (collected in Jinapsan Cave), and groundwater (collected at selected production wells) (Modified from Beal and others, 2019).

saltwater pressure of the underlying saltwater, the transition zone rises toward the open interval of these wells causing more saline water to enter the wells.

\section{Groundwater Conditions with Decreased Recharge in a Future Climate}

A model simulation of 2010 withdrawal rates with future recharge conditions and no change in sea level indicates a composite concentration of $282 \mathrm{mg} / \mathrm{L}$, which is more than double the composite concentration simulated for 2012 recharge and sea-level conditions (Gingerich, 2013) and above the $250 \mathrm{mg} / \mathrm{L}$ chloride concentration secondary standard established by the U.S. Environmental Protection Agency (EPA). Of the $40.3 \mathrm{Mgal} / \mathrm{d}$ withdrawn, 16 percent is in the threatened category, 27 percent is in the cautionary category and 47 production wells have concentration increases large enough to move the well into a higher concentration category (fig. 22B). 
$\boldsymbol{A}$

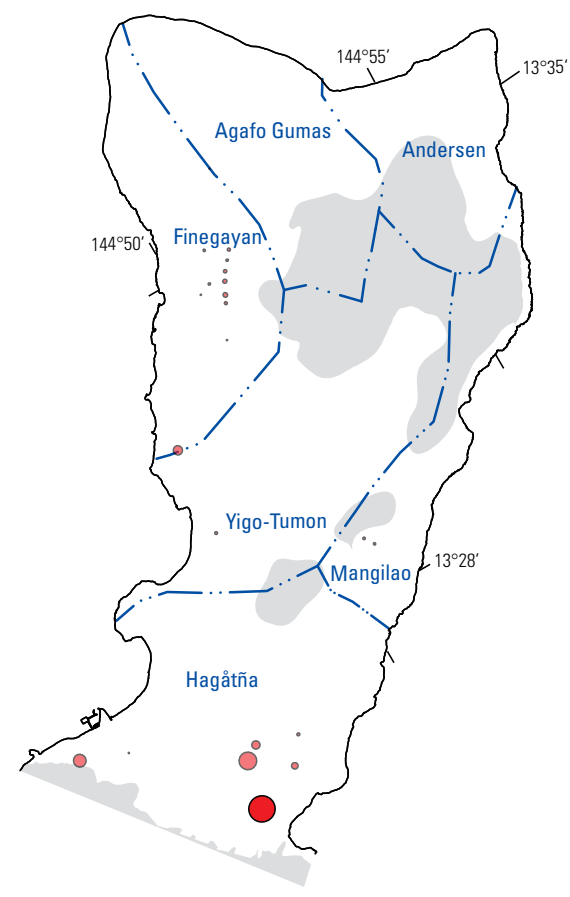

Base modified from U.S. Geological Survey National Hydrography Dataset. Universal Transverse Mercator projection, zone 55, WGS84 datum.
B

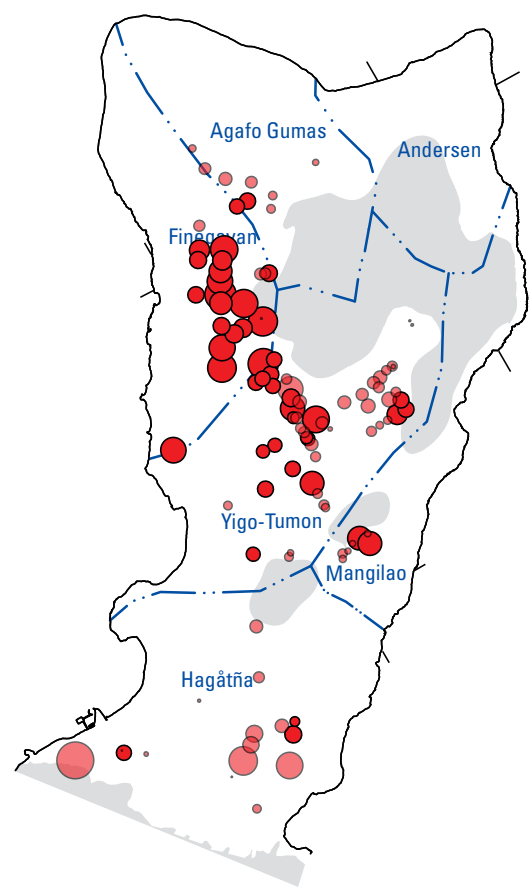

EXPLANATION

Well locations indicating increase in modeled salinityArea proportional to change in approximate chloride concentration in milligrams per liter

Chloride concentration $\quad 60 \quad 200 \quad 350$ (milligrams per Liter) 0 $c$
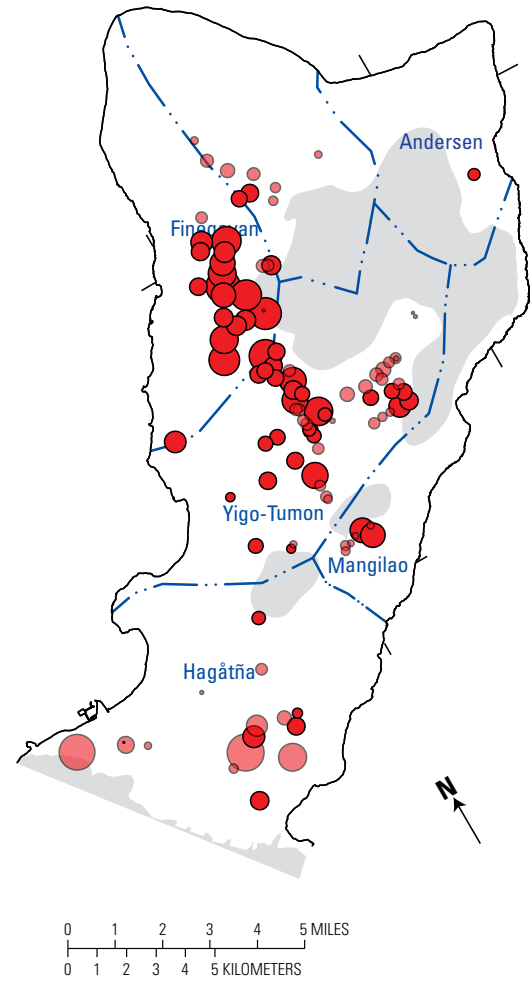

Volcanics above sea level

Watershed region boundary

Figure 22. Maps showing pumped wells with simulated salinity increases for future conditions (scenario Representative Concentration Pathway 8.5, 2080-99) in the Northern Guam Lens Aquifer, Guam. (A) 6.6-ft higher sea level. (B) 19-percent lower recharge. (C) 3.3-ft higher sea level and 19-percent lower recharge. Wells shown in dark red are those that have chloride-concentration increases large enough to move into a higher concentration category. Individual production wells are grouped into three categories: threatened (>500 mg/L chloride), cautionary $(200-500 \mathrm{mg} / \mathrm{L}$ chloride), or acceptable $(<200 \mathrm{mg} / \mathrm{L}$ chloride) based on the simulated chloride concentration of pumped water (after Gingerich, 2013).

\section{Groundwater Conditions with Increased Sea Level and Decreased Recharge in a Future Climate}

In a model simulation including the combined effects of $3.3 \mathrm{ft}$ of increased sea level (a projected increase having a relatively higher probability of occurring) and future recharge, the composite concentration is $304 \mathrm{mg} / \mathrm{L}$ or 8 percent larger than in the previous scenario under decreased recharge alone. This production-well composite is 20 percent above the chloride concentration secondary standard established by the USEPA. Of the $40.3 \mathrm{Mgal} / \mathrm{d}$ withdrawn, 17 percent is in the threatened category and 31 percent is in the cautionary category and 53 wells have concentration increases large enough to place each well into a higher concentration category relative to recent conditions (fig. $22 C$ ). The effect of combining sea-level increase with decreased recharge appears compounded relative to the effects of each scenario considered individually indicating that these two factors will exacerbate future impacts.

A two-year drought condition in which future recharge was decreased uniformly across the modeled area by 32 percent (a decrease similar to the one estimated for the historic 1969-73 drought) and sea level was $3.3 \mathrm{ft}$ higher than present was also simulated with the 2010 withdrawal rates held constant. This scenario represents generalized conditions, because the decrease in recharge during the 2-year drought is imposed immediately and held constant over the 2-year period, and model results are presented for a 2-year transient transport simulation with constant pumping to meet all assumed demands. At the end of one year, the composite concentration increases to $853 \mathrm{mg} / \mathrm{L}$ and of the $40.3 \mathrm{Mgal} / \mathrm{d}$ withdrawn, 70 percent is in the threatened category and 23 percent is in the cautionary category. Maintaining the 2010 rates for a second year increased the composite concentration to $914 \mathrm{mg} / \mathrm{L}$ with 72 percent of the withdrawal in the threatened category demonstrating high sensitivity to decreased recharge.

Finally, the projected future demand withdrawal distribution (Scenario 5 of Gingerich [2013]) was simulated in conditions of 3.3 -ft increased sea level and future recharge to evaluate the effectiveness of this improved withdrawal distribution in a future climate. For this simulated distribution, the composite 
concentration is $292 \mathrm{mg} / \mathrm{L}$, significantly greater than the composite concentration of $98 \mathrm{mg} / \mathrm{L}$ using the same withdrawal distribution during historic recharge conditions but a slight improvement over the composite concentration of $304 \mathrm{mg} / \mathrm{L}$ for the future scenario with the recent withdrawal distribution. Of the $46.5 \mathrm{Mgal} / \mathrm{d}$ withdrawn, 15 percent is in the threatened category and 42 percent is in the cautionary category. For this same future demand withdrawal distribution during historic recharge conditions, no withdrawn water was in the threatened category and 11 percent was in the cautionary category.

\section{Mitigation Strategies to Reduce Produced- Water Salinity}

Several practical strategies to lower the composite production-well salinity were evaluated with additional model simulations. These simulations provide insight into the hydrologic effectiveness of selected management and mitigation strategies but do not consider other variables that must be considered before adopting these strategies. The mitigation strategies investigated are: (1) reducing the depth of high-salinity production wells, (2) reducing the withdrawal rate at selected production wells with the highest salinities, and (3) a combination of (1) and (2) (fig. 23). All steady-state simulations are for an intermediate sea-level rise of $3.3 \mathrm{ft}$ and the future recharge estimate.

\section{Reducing the Depth of High-Salinity Production Wells}

This mitigation strategy involves reducing the depth of the production wells that penetrate near or into the freshwater/ saltwater transition zone and thus produce saltier water. In practice, the selected wells could be properly abandoned and replaced at the same location with wells drilled to a shallower depth. In this simulation, depths of the 55 deepest wells (table 4) with high salinities were reduced so that the base of each open interval only penetrated to the appropriate target depth recommended for production wells in the NGLA in Camp, Dresser \& McKee, Inc. (1982): $25 \mathrm{ft}$ below mean sea level (msl) in basal areas with freshwater heads less than $4 \mathrm{ft}$ above msl, $35 \mathrm{ft}$ below msl in basal areas with freshwater heads greater than $4 \mathrm{ft}$ above $\mathrm{msl}$, and $50 \mathrm{ft}$ below msl in parabasal zones. Basal and parabasal areas were those defined in Vann and others (2013) using recent sea level. Future recharge was used and withdrawal of $46.5 \mathrm{Mgal} / \mathrm{d}$ was the projected future withdrawal distribution (Scenario 5 of Gingerich, 2013).

From this simulation with reduced-depth wells, the composite concentration is $224 \mathrm{mg} / \mathrm{L}$, or 23-percent lower than the composite concentration of $292 \mathrm{mg} / \mathrm{L}$ using existing well depths. Of the $46.5 \mathrm{Mgal} / \mathrm{d}$ withdrawn, 9 percent is in the threatened category and 42 percent is in the cautionary category, an overall improvement from the 16 percent threatened and 40 percent cautionary results from the simulation using existing well depths.
Table 4. Wells for which depth or withdrawal rate was modified for mitigation strategy simulations.

\begin{tabular}{|c|c|c|c|}
\hline \multicolumn{4}{|c|}{ Reduced depth } \\
\hline Well & Depth, in feet & Well & Depth, in feet \\
\hline A09 & 35 & F06 & 25 \\
\hline A13 & 35 & F07 & 25 \\
\hline A14 & 25 & F08 & 25 \\
\hline A15 & 25 & F09 & 25 \\
\hline A17 & 25 & F10 & 25 \\
\hline A18 & 25 & F11 & 25 \\
\hline A21 & 25 & F13 & 25 \\
\hline AF02 & 25 & F17 & 50 \\
\hline AF03 & 25 & F19 & 25 \\
\hline AF04 & 25 & $\mathrm{~F} 20$ & 25 \\
\hline D01 & 25 & GH501 & 25 \\
\hline D02 & 25 & M05 & 25 \\
\hline D05 & 25 & M06 & 25 \\
\hline D06 & 25 & M09 & 50 \\
\hline D07 & 25 & M12 & 25 \\
\hline D08 & 25 & M21 & 25 \\
\hline D09 & 25 & NAS01 & 50 \\
\hline D13 & 50 & NCS10 & 25 \\
\hline D14 & 25 & NCS11 & 25 \\
\hline D15 & 25 & NCS12 & 25 \\
\hline D16 & 25 & Y04 & 35 \\
\hline D20 & 25 & Y05 & 35 \\
\hline D26 & 50 & Y10 & 25 \\
\hline F01 & 25 & Y12 & 25 \\
\hline F02 & 25 & Y16 & 35 \\
\hline F03 & 25 & Y20 & 35 \\
\hline F04 & 25 & Y22 & 25 \\
\hline F05 & 25 & & \\
\hline \multicolumn{4}{|c|}{ Reduced withdrawal rate } \\
\hline Well & $\begin{array}{c}\text { Percentage } \\
\text { rate reduction }\end{array}$ & Well & $\begin{array}{c}\text { Percentage } \\
\text { rate reduction }\end{array}$ \\
\hline A09 & 18 & F04 & 100 \\
\hline A10 & 33 & F10 & 100 \\
\hline A13 & 100 & F11 & 100 \\
\hline A17 & 50 & F13 & 100 \\
\hline A21 & 20 & F19 & 100 \\
\hline D08 & 100 & $\mathrm{~F} 20$ & 100 \\
\hline D09 & 100 & GH501 & 100 \\
\hline D24 & 100 & M06 & 100 \\
\hline D26 & 100 & M09 & 100 \\
\hline F01 & 100 & MW06 & 50 \\
\hline F02 & 100 & NCS10 & 100 \\
\hline \multicolumn{4}{|c|}{ Reduced depth and withdrawal rate } \\
\hline & Well & Depth, in feet & $\begin{array}{c}\text { Percentage } \\
\text { rate reduction }\end{array}$ \\
\hline & A09 & 35 & 27 \\
\hline & A10 & - & 33 \\
\hline & A 13 & 35 & 0 \\
\hline
\end{tabular}




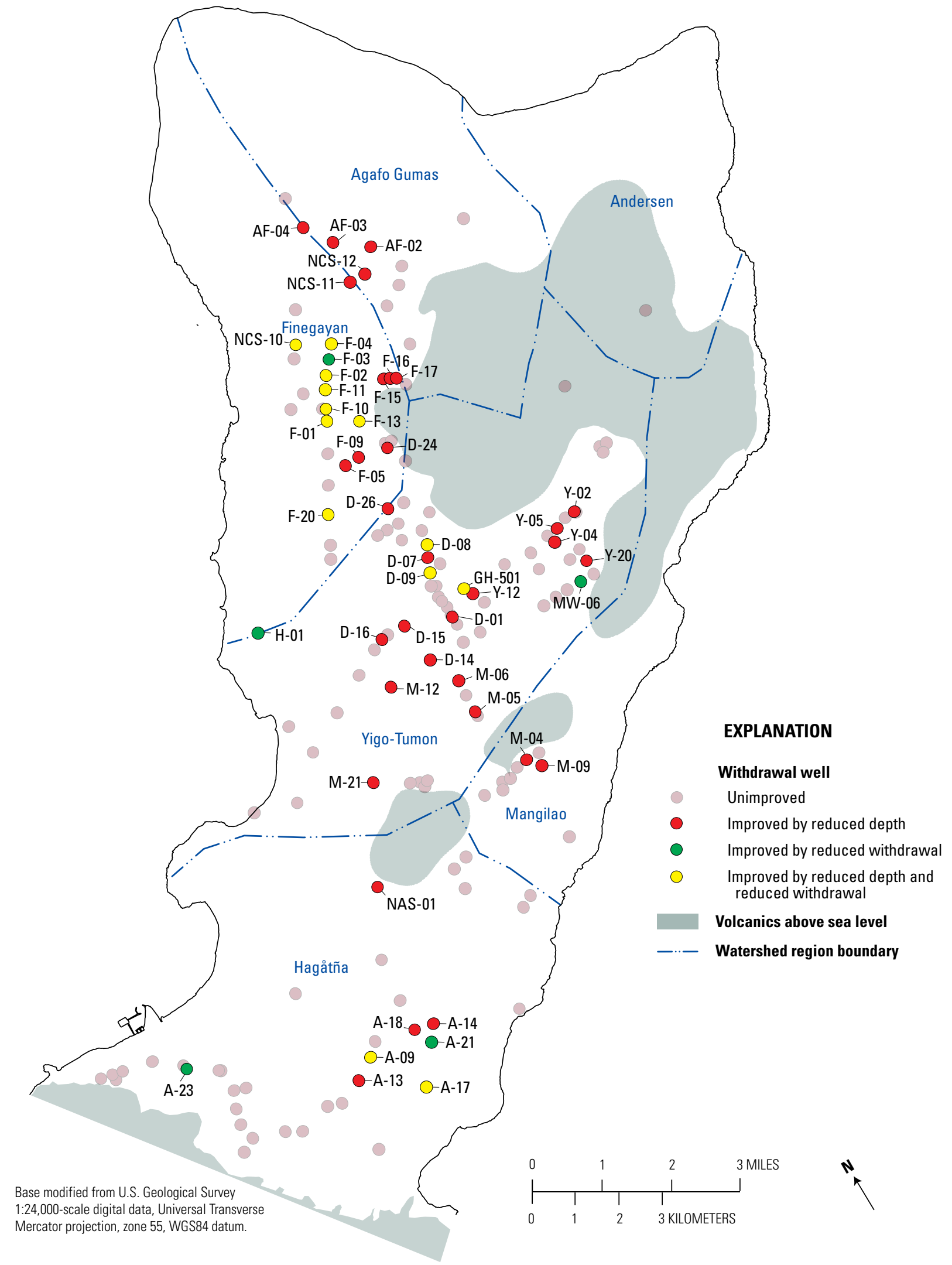

Figure 23. Map of withdrawal wells in which salinity would be reduced by shortening well depths or reducing withdrawal rates in the future (scenario Representative Concentration Pathway 8.5, 2080-99) recharge scenario, Northern Guam Lens Aquifer, Guam. Aquifer subbasin names and boundaries are indicated from Gingerich, 2013 
Table 4.-Continued

\begin{tabular}{|ccc|}
\hline \multicolumn{2}{c}{ Reduced depth and withdrawal rate } & \\
\hline Well & Depth, in feet & $\begin{array}{c}\text { Percentage } \\
\text { rate reduction }\end{array}$ \\
\hline A14 & 25 & 0 \\
\hline A15 & 25 & 0 \\
\hline A17 & 25 & 50 \\
\hline A18 & 25 & 0 \\
\hline A21 & 25 & 24 \\
\hline AF02 & 25 & 0 \\
\hline AF03 & 25 & 0 \\
\hline AF04 & 25 & 0 \\
\hline D01 & 25 & 0 \\
\hline D02 & 25 & 0 \\
\hline D05 & 25 & 0 \\
\hline D06 & 25 & 0 \\
\hline D07 & 25 & 0 \\
\hline D08 & 25 & 0 \\
\hline D09 & 25 & 0 \\
\hline D13 & 50 & 100 \\
\hline D14 & 25 & 0 \\
\hline D15 & 25 & 0 \\
\hline D16 & 25 & 0 \\
\hline D20 & 25 & 0 \\
\hline D21 & 25 & 0 \\
\hline D26 & 50 & 0 \\
\hline F01 & 25 & 0 \\
\hline F02 & 25 & 0 \\
\hline F03 & 25 & 0 \\
\hline F04 & 25 & 0 \\
\hline F05 & 25 & 0 \\
\hline & 25 & 0 \\
\hline
\end{tabular}

\section{Reducing Withdrawal at High-Salinity Production Wells}

This mitigation strategy involves reducing the withdrawal rates of the production wells that are producing the most saline water so that no wells produced water with concentrations in the threatened category. Twenty-two production wells (at full production rates) are projected to be in the threatened category in a future climate with less recharge and sea-level rise. In this simulation, withdrawal from each of the 22 wells (table 4) was reduced by trial and error until their concentrations decreased below the threatened category threshold. At 17 of the 22 reduced-withdrawal wells, withdrawal was eliminated. Total production decreased by 11 percent, dropping from $46.5 \mathrm{Mgal} / \mathrm{d}$ to $41.4 \mathrm{Mgal} / \mathrm{d}$, and the resulting composite concentration decreased to $192 \mathrm{mg} / \mathrm{L}$. Of the total volume withdrawn, 47 percent remained in the cautionary category, with no wells in the threatened category as stipulated by the constraints of this scenario. A formal optimization could produce further improvements relative to these trial-and-error results, however, for this study, the findings

\begin{tabular}{|ccc}
\hline \multicolumn{2}{c}{ Reduced depth and withdrawal rate } \\
\hline Well & Depth, in feet & $\begin{array}{c}\text { Percentage } \\
\text { rate reduction }\end{array}$ \\
\hline F06 & 25 & 100 \\
\hline F07 & 25 & 0 \\
\hline F09 & 25 & 0 \\
\hline F10 & 25 & 10 \\
\hline F11 & 25 & 0 \\
\hline F13 & 25 & 0 \\
\hline F17 & 50 & 0 \\
\hline F19 & 25 & 100 \\
\hline F20 & 25 & 0 \\
\hline GH501 & 25 & 50 \\
\hline M05 & 25 & 0 \\
\hline M06 & 25 & 0 \\
\hline M09 & 50 & 0 \\
\hline M12 & 25 & 0 \\
\hline M21 & 0 \\
\hline MW06 & 25 & 50 \\
\hline NAS01 & 50 & 0 \\
\hline NCS10 & 60 \\
\hline NCS11 & 50 & 0 \\
\hline NCS12 & 25 & 0 \\
\hline Y04 & 25 & 0 \\
\hline Y05 & 25 & 0 \\
\hline Y10 & 35 & 0 \\
\hline Y12 & 35 & 0 \\
\hline Y16 & 25 & 0 \\
\hline Y20 & 25 & 0 \\
\hline Y22 & 35 & 0 \\
\hline & 35 & \\
\hline & 25 & \\
\hline
\end{tabular}

presented here are considered sufficient to demonstrate that reduced withdrawal at threatened wells will decrease composite concentration.

\section{Reducing Well Depths and Withdrawal Rates}

The following is a combination of the previous two strategies; reducing depths of 56 wells that are deep and then reducing the withdrawal rate at 12 wells by trial and error until all wells produce water in the cautionary or acceptable categories. At 4 of these 12 wells, withdrawal was eliminated (table 4). The resulting withdrawal distribution produces a composite concentration of $196 \mathrm{mg} / \mathrm{L}$ from about 3 percent less water $(45 \mathrm{Mgal} / \mathrm{d})$ than the scenario using the projected future withdrawal. This composite is lower than that $(224 \mathrm{mg} / \mathrm{L})$ of the strategy of only reducing well depths, and similar to that $(192 \mathrm{mg} / \mathrm{L})$ of the strategy of only reducing withdrawal rates. This combined strategy, however, produces about 9 percent more water than the strategy of reducing withdrawal rates only. Of the total production, 45 percent is in the cautionary category (fig. 24). 
$\boldsymbol{A}$

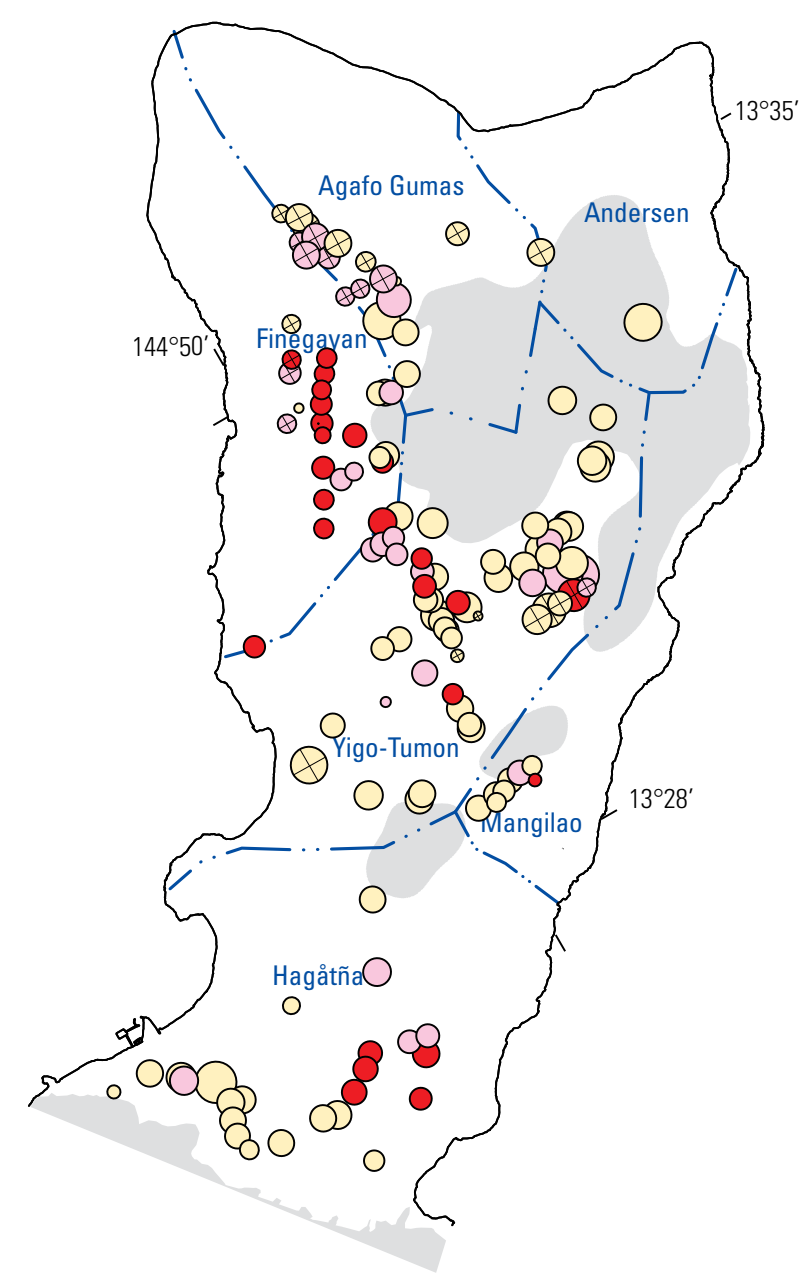

Base modified from U.S. Geological Survey National Hydrography Dataset. Universal Transverse Mercator projection, zone 55, WGS84 datum.

\section{EXPLANATION}

Well location indicating withdrawal rate and modeled salinityArea proportional to rate in million gallons per day (Mgal/d) and color indicating approximate chloride concentration in milligrams per liter $(\mathrm{mg} / \mathrm{L})$; tan is acceptable $(<200 \mathrm{mg} / \mathrm{L})$, pink is cautionary (200 to $500 \mathrm{mg} / \mathrm{L})$, and red (>500 mg/L) is threatened

$\begin{array}{lccc}\text { Symbol area } & 0.25 & 0.5 & 1.0 \\ \text { (million gallons per day) } & \bigcirc & \bigcirc & >500 \\ \text { Chloride concentration } & <200 & 200-500 & \bigcirc \\ \text { (milligrams per Liter) } & \bigcirc & \bigcirc & \text { Threatened }\end{array}$

Figure 24. Maps showing simulated salinity for future recharge (scenario Representative Concentration Pathway 8.5, 2080-99) at pumped wells in the Northern Guam Lens Aquifer, Guam. (A) Original scenario with existing well depths and projected future withdrawal. (B) Scenario with shortened wells and reduced withdrawal. 


\section{Study Limitations}

The surface-water and groundwater models used in this study are practical tools that make it possible to simulate complex natural systems through sets of mathematical equations and empirical relations representing and approximating the major components of the hydrologic cycle and hydrologic processes involved. As a result of the assumptions and simplifications that must be made, error and uncertainty are built into the models. Even though the models capture some of the heterogeneity of the hydrologic characteristics, these characteristics still must be simplified into assumed homogenous units. Models in general are also limited by errors associated with the input data. The quality and accuracy of time-series data for inputs such as rainfall, temperature, streamflow, diversion, groundwater recharge, and groundwater withdrawal affect the accuracy of the hydrologic simulation results. Calibration and verification were done for a specific time period and range of streamflow or groundwater conditions; therefore, it is uncertain how the models will perform under different conditions. The accuracy of groundwater recharge estimated using the water-budget model is limited by the quality and availability of data needed to develop model input-land cover, rainfall, irrigation, runoff, soil properties, and evapotranspiration. Initiation of and continued research to characterize these parameters would improve overall confidence in recharge estimates. The primary limitations of the Fena Valley reservoir sedimentation model are related to the use of a stable relation between discharge and sediment load. This relation can change over long timescales (for example, watershed land use changes) and short timescales (for example, limited sediment supply during individual flood events and seasonal changes). However, because of its simplicity and easy application with daily discharge data, which is often available, the stable dischargesediment load relationship provides an attractive alternative to develop a first-order estimate of the daily variability in reservoir deposition rates in a data-sparse environment.

The projections of future water-resource conditions are, of course, limited by the uncertainty in the estimates of future climate. The estimates of future climate are based on an averaging of global climate models that all contain inherent uncertainty. The assumption is that the selected models that "best" represent the recent climate and its variation are expected to provide a robust estimate of future climate, and thereby reduce uncertainty. Combining output from global climate models and dynamical and statistical downscaling models using advanced averaging, weighting, and pattern scaling approaches can result in more relevant and robust future projections (Hayhoe and others, 2017). The regional-model experimental design warrants that only the current ENSO and PDO conditions are maintained and assumes no changes to these variabilities in the future (a limitation of this pseudowarming experimental design). A focus on the long-term trend in climate variables is preserved; however, changes in future ENSO or PDO conditions could produce different results than are projected here. Furthermore, the RCP8.5 radiative forcing scenario reflects the upper range of the open literature on carbon emissions, but it is not intended to serve as an upper limit on possible emissions nor as a reference scenario for other scenarios of less radiative forcing. Within the RCP family, individual scenarios have not been assigned a formal likelihood (Hayhoe and others, 2017). Likewise, the results presented in this study, which are based on the RCP8.5 scenario, are not assigned a likelihood of occurring.

\section{Conclusions}

Guam's water resources in a future climate condition (2080-99) are projected to diminish relative to the recent climate condition. Future average temperature increases, and average rainfall decreases will lead to reduced streamflow in southern Guam and reduced groundwater recharge to the Northern Guam Lens Aquifer (NGLA). In the projected future climate, average temperatures in southern Guam will increase about $3.2^{\circ} \mathrm{C}\left(5.8^{\circ} \mathrm{F}\right)$, overall rainfall will decrease about 7 percent, and, streamflow will consequently decrease 18 percent in parts of southern Guam. Similarly, across the NGLA, future groundwater recharge will be 19 percent less than average estimated recharge during 1961-2005.

Reduced future streamflow will decrease water availability from the Fena Valley Reservoir (FVR). Withdrawal rates representative of recent (2010-14) demand will lead to one more month in conservation level IV (the second least-restrictive level), during future climate conditions. However, the FVR is expected to be able to supply water at recent demand rates without lowering the reservoir level to the elevation of the water-supply intakes throughout the simulated period with a future climate. Simulations with increased withdrawal rates in a future climate indicate that the maximum rate the FVR can supply over the 12-year simulation without lowering the reservoir level to the intakes is $11.4 \mathrm{Mgal} / \mathrm{d}$, about twice the recent demand.

The evaluated mitigation strategies to increase FVR water availability in a future climate with less streamflow were lowering the water-supply intakes, increasing the spillway height, and a combination of both. Each of these strategies allow a higher constant withdrawal rate from FVR (with the constraint of keeping the reservoir level just above the elevation of the water-supply intake), when compared with the rate allowed in a future climate with the same constraint but without modifying the intake elevation or spillway height. Specifically, the constant withdrawal rate can be increased (1) by 1.7 percent if the water-supply intakes are lowered $5 \mathrm{ft}$, (2) by 3.5 percent if the spillway height is raised $5 \mathrm{ft}$, and (3) by 5.3 percent if strategies 1 and 2 are combined.

Higher sea level and reduced future recharge will decrease water availability from the NGLA. The composite chloride concentration (an overall withdrawal-weighted average concentration) from production wells increases to $304 \mathrm{mg} / \mathrm{L}$ (well above the drinking water standard of $250 \mathrm{mg} / \mathrm{L}$ ) for 2010 withdrawal rates under future climate conditions, compared with $126 \mathrm{mg} / \mathrm{L}$ under historic climate conditions. Most of this increase is due to reduced groundwater recharge because higher sea level 
only has a small role in increasing withdrawn water salinity. A redistributed withdrawal scenario in which the composite concentration is $291 \mathrm{mg} / \mathrm{L}$ offers only slight improvement. Should future droughts reduce recharge proportionally to the decreases observed during historic droughts, the composite concentration would be about $900 \mathrm{mg} / \mathrm{L}$ after two years of drought and more than 70 percent of Guam's production wells would produce water with a composite concentration greater than $500 \mathrm{mg} / \mathrm{L}$.

The evaluated mitigation strategies for increasing the potable yield of the NGLA in a future climate were reducing depths of deep production wells and reducing the withdrawal rates in selected wells projected to have higher chloride concentrations. A simulation including both strategies for the redistributed withdrawal scenario shows a significant improvement in composite concentration and volume of withdrawn water. The composite chloride concentration is lowered to $191 \mathrm{mg} / \mathrm{L}$ and the available yield is increased by 9 percent. In practical terms, these strategies would most likely have to be implemented by abandoning the deep wells and replacing them with shallower wells, by installing variable speed pumps in all production wells to allow each well's actual withdrawal rate to be set at its ideal withdrawal rate, and by having a fully integrated water system that would allow water to be piped to areas of greatest demand from areas of greatest supply.

\section{References Cited}

Allen, R.G., Pereira, L.S., Raes D., and Smith, M., 1998, Crop evapotranspiration; guidelines for computing crop water requirements: Food and Agriculture Organization of the United Nations, FAO Irrigation and Drainage Paper 56, Rome, accessed at http://www.fao.org/docrep/X0490E/ X0490E00.htm.

Allen, R.G., Pruitt, W.O., Wright, J.L., Howell, T.A., Ventura, F., Snyder, R., Itenfisu, D., Steduto, P., Berengena, J., Yrisarry, J.B., Smith, M., Pereira, L.S., Raes D., Perrier, A., Alves, I., Walter, I., and Elliott, R., 2006, A recommendation on standardized surface resistance for hourly calculation of reference ETo by the FAO56 PenmanMonteith method: Agricultural Water Management, v. 81, no.1-2, p. 1-22, accessed at https://doi.org/10.1016/j. agwat.2005.03.007.

Arnell N.W. and Reynard N.S., 1996, The effects of climate change due to global warming on river flows in Great Britain: Journal of Hydrology, v. 183, no. 3-4, p. 397-424, accessed at https://doi.org/10.1016/0022-1694(95)02950-8.

Bautista, K.K, 2017, Vadose Hydrology at Jinapsan Cave, Northern Guam: Mangilao, Guam, University of Guam Master's Thesis, 209 p.
Beal, L.K., Wong, C.I., Bautista, K.K., Jenson, J.W., Banner, J.L., Lander, M.A., Gingerich, S.B., Partin, J.W., Hardt, B., and van Oort, N.H., 2019, Isotopic and geochemical assessment of the sensitivity of groundwater resources of Guam, Mariana Islands, to intra- and inter-annual variations in hydroclimate: Journal of Hydrology, v. 568, p. 174-183, accessed at https://doi.org/10.1016/j.jhydrol.2018.10.049

Camargo, S.J., Emanuel, K.A., and Sobel, A.H., 2007, Use of a genesis potential index to diagnose ENSO effects on tropical cyclone genesis: Journal of Climatology., v. 20, p. $4,819-4,834$.

Camp, Dresser \& McKee, Inc., 1982, Northern Guam Lens Study, Groundwater Management Program, Summary Report, prepared for the Government of Guam [variously paged].

Carlson, E., Doyle, D., and Smith, D., 2009, Development of comprehensive geodetic vertical datums for the United States Pacific Territories of American Samoa, Guam, and the Northern Marianas: Surveying and Land Information Science, v. 69, no. 1, p. 5-17.

Chand, S.S., Tory, K.J., Ye, H., and Walsh, K.J.E., 2017, Projected increase in El Niño-driven tropical cyclone frequency in the Pacific: Nature Climate Change, v. 7, p. 123-127, accessed at https:/www.doi.org/10.1038/ nclimate 3181 .

Chase, K.J., Haj, A.E., Regan, R.S., and Viger, R.J., 2016, Potential effects of climate change on streamflow for seven watersheds in eastern and central Montana: Journal of Hydrology—Regional Studies, v. 7, p. 69-81.

Christensen, J.H., Kanikicharla, K.K., Aldrian, E., An, S.-II., Cavalcanti, I.F.A., de Castro, M., Dong, W., Goswami, P., Hall, A., Kanyanga, J.K., Kitoh, A., Kossin, J., Lau, N.-C., Renwick, J., Stephenson, D.B., Xie, S.-P., and Zhou, T., 2013, Climate phenomena and their relevance for future regional climate change in Stocker, T. F., Qin. D., Plattner, G.-K., Tignor, M., Allen, S.K., Boschung, J., Nauels, A., Xia, Y., Bex, V., and Midgley, P.M., eds., Climate Change 2013-The Physical Science Basis; Contribution of Working Group I to the Fifth Assessment Report of the Intergovernmental Panel on Climate Change: Cambridge, United Kingdom and New York, NY, USA, Cambridge University Press.

Contractor, D.N. and Srivastava, R., 1990, Simulation of saltwater intrusion in the Northern Guam Lens using a microcomputer: Journal of Hydrology, v. 118, p. 87-106.

Contractor, D.N. and Jenson, J.W., 2000, Simulated effect of vadose infiltration on water levels in the Northern Guam Lens Aquifer: Journal of Hydrology, v. 229, p. 232-254. 
Daly, C. and Halbleib, M., 2006, Pacific Islands (Guam) average monthly and annual precipitation, 1971-2000: PRISM Group at Oregon State University, accessed at http://www.prism. oregonstate.edu/projects/pacific_islands.php.

Dee, D.P. and Uppala, S., 2009, Variational bias correction of satellite radiance data in the ERA-interim reanalysis: Quarterly Journal of the Royal Meteorology Society, v. 135, p. $1,830-1,841$.

Emanuel, K.A., 1995, Sensitivity of tropical cyclones to surface exchange coefficients and a revised steady-state model incorporating eye dynamics: Journal of the Atmospheric Sciences, v. 52, no. 22, p. 3,969-3,976.

Emanuel, K.A., 1999, Thermodynamic control of hurricane intensity: Nature, v. 401, p. 665-669.

Finucane, M.L. and Gullion, C.M., 2010, Developing a tool for measuring the decision-making competence of older adults: Psychology and Aging, v. 25, no. 2, p. 271-288, accessed at https://doi.org/10.1037/a0019106.

Flato, G., Marotzke, J., Abiodun, B., Braconnot, P., Chou, S.C., Collins, W., Cox, P., Driouech, F., Emori, S., Eyring, V., Forest, C., Gleckler, P., Guilyardi, E., Jakob, C., Kattsov, V., Reason, C., and Rummukainen, M., 2013, Evaluation of Climate Models in Stocker, T.F., D. Qin, G.-K. Plattner, M. Tignor, S.K. Allen, J. Boschung, A. Nauels, Y. Xia, V. Bex and P.M. Midgley, eds., Climate Change 2013-The Physical Science Basis; Contribution of Working Group I to the Fifth Assessment Report of the Intergovernmental Panel on Climate Change: Cambridge, United Kingdom and New York, NY, USA, Cambridge University Press.

Fontaine, R.A., 2003, Flooding associated with Typhoon Chata'an, July 5, 2002, Guam: U.S. Geological Survey Fact Sheet 061-03, 6 p.

Frederic R. Harris, Inc., 1949, Impounding reservoir area and volume curves, architecture and engineering drawing 134-2: San Francisco, Calif., Frederic Harris, Inc.

Gingerich, S.B., 2003, Hydrologic Resources of Guam: U.S. Geological Survey Water-Resources Investigations Report 03-4126, 2 Plates.

Gingerich, S.B., 2013, The effects of withdrawals and drought on groundwater availability in the Northern Guam Lens Aquifer, Guam: U.S. Geological Survey Scientific Investigations Report 2013-5216, 76 p., accessed at https://doi.org/10.3133/ $\operatorname{sir} 20135216$.

Gingerich, S.B., 2019, SUTRA model used to evaluate the freshwater flow system for a future (2080-2099) climate on Guam, U.S. Geological Survey Data Release, accessed at https://doi.org/10.5066/P9U34ACT.
Gingerich, S.B. and Jenson, J.W., 2010, Groundwater availability study for Guam; goals, approach, products, and schedule of activities: U.S. Geological Survey Fact Sheet 2010-3084, 4 p., accessed at https://pubs.usgs.gov/ fs/2010/3084/

Gingerich, S.B., Keener, V., and Finucane, M.L., 2019a, Guam's water resources, Honolulu, Hawai' $i$, East-West Center, $2 \mathrm{p}$.

Gingerich, S.B., Keener, V., and Finucane, M.L., 2019b, Freshwater availability in Guam with projected changes in climate: Honolulu, Hawai' $i$, East-West Center, 4 p.

Gingerich, S.B., Voss, C.I. and Johnson, A.G., 2017, Seawaterflooding events and impact on freshwater lenses of lowlying islands - Controlling factors, basic management and mitigation: Journal of Hydrology, 551, p. 676-688, accessed at https://doi.org/10.1016/j.jhydrol.2017.03.001.

Gray, W.M., 1979, Hurricanes-Their formation, structure and likely role in the tropical circulation in Shaw, D.B., ed., Meteorology over the Tropical Oceans: Royal Meteorological Society p. 155-218.

Guam Waterworks Authority, 2017, Agency website accessed November 13, 2017 online at http://guamwaterworks.org/ operations-maintenance/.

Hay, L.E., Wilby, R.L., and Leavesley, G.H., 2000, A comparison of delta change and downscaled GCM scenarios for three mountainous basins in the United States: Journal of the American Water Resources Association, v. 36, no. 2, p. 387-397, accessed at https://onlinelibrary.wiley.com/doi/ epdf/10.1111/j.1752-1688.2000.tb04276.x.

Hayhoe, K., J. Edmonds, R.E. Kopp, A.N. LeGrande, B.M. Sanderson, M.F. Wehner, and D.J. Wuebbles, 2017, Climate models, scenarios, and projections in Wuebbles, D.J., Fahey, D.W., Hibbard, K.A., Dokken, D.J., Stewart, B.C., and Maycock, T.K., eds., Climate Science Special Report: Fourth National Climate Assessment, Volume I. U.S. Global Change Research Program, Washington, DC, USA, pp. 133-160, accessed at https://doi.org/10.7930/J0WH2N54.

Intergovernmental Panel on Climate Change, 2013, Summary for Policymakers in Stocker, T.F., D. Qin, G.-K. Plattner, M. Tignor, S.K. Allen, J. Boschung, A. Nauels, Y. Xia, V. Bex and P.M. Midgley, eds., The Physical Science BasisContribution of Working Group I to the Fifth Assessment Report of the Intergovernmental Panel on Climate Change: Cambridge, United Kingdom and New York, USA, Cambridge University Press, accessed at http://www.ipcc. ch/pdf/assessment-report/ar5/wg1/WG1AR5_SPM_FINAL. pdf. 
Jenson, J.W., Keel, T.M., Mylroie, J.R., Mylroie, J.E., Stafford, K.W., Taboroši, D., and Wexel, C., 2006, Karst of the Mariana Islands - The interaction of tectonics, glacio-eustasy, and freshwater/seawater mixing in island carbonates: Geological Society of America Volume 404 (Special Paper), p. 129-138, accessed at https://doi.org/10.1130/2006.2404(11).

Jocson, J.M.U., Jenson, J.W., and Contractor, D.N., 1999, Numerical modeling and field investigation of infiltration, recharge, and discharge in the Northern Guam Lens Aquifer: Mangilao, Guam, University of Guam, Water and Environmental Research Institute of the Western Pacific, Technical Report No. 88, Mangilao, Guam, 22 p.

Jocson, J.M.U., Jenson, J.W., and Contractor, D.N., 2002, Recharge and aquifer response- Northern Guam Lens Aquifer, Guam, Mariana Islands: Journal of Hydrology, v. 260, p. $231-254$.

Johnson A.G., 2012, A water-budget model and estimates of groundwater recharge for Guam: U.S. Geological Survey Scientific Investigations Report 2012-5028, 53 p., accessed at https://pubs.usgs.gov/sir/2012/5028/.

Johnson, A.G., 2019, Mean annual water-budget components for Guam for historic (1990-2009) and future (2080-2099) climate conditions, Data Release. U.S. Geological Survey Data Release accessed at https://doi.org/10.5066/P9A64801.

Kennedy Engineers, Inc., 1974, Fena watershed and reservoir management and study plan - Phase I and II: San Francisco, Kennedy Engineers, Inc., 139 p.

Kimura, F. and Kitoh, A., 2007, Downscaling by pseudo global warming method-The Final Report of the ICCAP: Kyoto, Japan, Research Institute for Humanity and Nature (RIHN), 4 p.

Knapp, K.R., Kruk, M.C., Levinson, D.H., Diamond, H.J., and Neumann, C.J., 2010, The International Best Track Archive for Climate Stewardship (IBTrACS) - Unifying tropical cyclone data: Bulletin of the American Meteorological Society, v. 91, p. 363-376.

Knutson, T.R., McBride, J.L., Chan, J., Emanuel, K., Holland, G., Landsea, C., Held, I., Kossin. J.P., Srivastava, A.K., and Sugi, M., 2010, Tropical cyclones and climate change: Nature Geoscience, v. 3, p. 157-163.

Marineau, M.D., and Wright, S.A, 2015, Storage capacity of the Fena Valley Reservoir, Guam, Mariana Islands, 2014: U.S. Geological Survey Scientific Investigations Report 2015-5128, 31 p., accessed at https://doi.org/10.3133/sir20155128.

Marineau M.D., and Wright S.A., 2017, Daily reservoir sedimentation model: Case study from the Fena Valley Reservoir, Guam: Journal of Hydraulic Engineering, v. 143, no. 9, accessed at https://doi.org/10.1061/(ASCE)HY.19437900.0001344.
Markstrom, S.L., Regan, R.S., Hay, L.E., Viger, R.J., Webb, R.M.T., Payn, R.A., and LaFontaine, J.H., 2015, PRMS-IV, the precipitation-runoff modeling system, version 4: U.S. Geological Survey Techniques and Methods, book 6, chap. B7, 158 p., accessed at https://doi.org/10.3133/tm6B7.

Mink, J.F., 1991, Groundwater in northern Guam; Sustainable yield and groundwater development: Barrett Consulting Group for the Public Utility Agency of Guam [variously paged].

Morgan, M.G., Fischhoff, B., Bostrom, A., and Atman, C.J., 2002, Risk Communication-A Mental Models Approach: New York, USA, Cambridge University Press, 366 p.

Moser, S.C., 2011, The contextual importance of uncertainty in climate-sensitive decision-making: Toward an integrative decision-centered screening tool in Dietz, T. and Bidwell, D., Climate Change in the Great Lakes Region-Navigating an Uncertain Future: East Lansing, Michigan, Michigan State University Press, p. 179-212.

Mylroie, J.E., Jenson, J.W., Taboroši, D, Jocson, J.M.U., Vann, D.T., and Wexel, C., 2001, Karst features on Guam in terms of a general model of carbonate island karst: Journal of Cave and Karst Studies, v. 63, no. 1, p. 9-22.

Nakama, L.Y., 1992, Storage capacity of Fena Valley Reservoir, Guam, Mariana Islands, 1990: U.S. Geological Survey Water-Resources Investigations Report 92-4114, $17 \mathrm{p}$.

Naval Base Guam, 2012, Water Conservation Program and Measures: Naval Base Guam Instruction 11330.1A, Guam, $21 \mathrm{p}$.

National Oceanic and Atmospheric Administration Office for Coastal Management, 2017, Guam and Saipan EditionDigital Coast Sea Level Rise Viewer: National Oceanic and Atmospheric Administration, accessed on April 4, 2017 at https://coast.noaa.gov/slrdata/

Riahi, K., Rao, S., Krey, V., Cho, C., Chirkov, V., Fischer, G., Kindermann, G., Nakicenovic, N., and Rafaj, P., 2011, RCP 8.5-A scenario of comparatively high greenhouse gas emissions: Climatic Change, v. 109, no. 1-2, p. 33-57.

Rosa S.N., 2019, Southern Guam watershed model and Fena Valley Reservoir water-balance model input files for historic (1990-2009) and future (2080-2099) climate conditions: U.S. Geological Survey Data Release, accessed at https://doi. org/10.5066/P90S1CSX

Rosa, S.N. and Hay, L.E., 2017a, Fena Valley Reservoir watershed and water-balance model updates and expansion of watershed modeling to southern Guam: U.S. Geological Survey Scientific Investigations Report 2017-5093, 64 p., accessed at https://doi.org/10.3133/sir20175093. 
Rosa, S.N. and Hay, L.E., 2017b, Supporting data for Fena Valley Reservoir watershed and water-balance model, southern Guam: U.S. Geological Survey data release, accessed at https://doi. org/10.5066/ F7HH6HV4.

Rotzoll, Kolja, Gingerich, S.B., Jenson, J.W., and El-Kadi, A.I., 2013, Estimating hydraulic properties from tidal attenuation in the Northern Guam Lens Aquifer, Territory of Guam, USA: Hydrogeology Journal, v. 21, no. 3, p. 643-654, accessed at https://doi.org/10.1007/s10040-012-0949-9.

Shalilian, I., 2017, Hydrogeology of the Finegayan Basin, Northern Guam Lens Aquifer: Mangilao, Gaum, University of Guam, Master's Thesis, 92 p. plus appendices.

Slovic, P., 1995, The construction of preference: American Psychologist, v. 50, no. 5, p. 364-371.

Storlazzi, C.D., Gingerich, S.B., van Dongeren, A., Cheriton, O.M., Swarzenski, P.W., Quataert, E., Voss, C.I., Field, D.W., Annamalai, H., Piniak, G.A., and McCall, R., 2018, Most atolls will be uninhabitable by the mid-21st century because of sea-level rise exacerbating wave-driven flooding: Science Advances, v. 4, eaap9741, accessed at https://doi.org/10.1126/ sciadv.aap9741.

Strachan, J., Vidale, P.L., Hodges, K., Roberts, M., and Demory, M.-E., 2013, Investigating global tropical cyclone activity with a hierarchy of AGCMs - The role of model resolution: Journal of Climate, v. 26, p. 133-152.

Sweet W.V., Kopp, R.E., Weaver, C.P., Obeysekera, J., Horton, R.M., Thieler, E.R. and Zervas, C., 2017, Global and regional sea level rise scenarios for the United States: Silver Spring, Maryland, National Oceanic and Atmospheric Administration Technical Report NOS CO-OPS 083, NOAA/NOS Center for Operational Oceanographic Products and Services, 75 p.

Taylor, K.E., 2001, Summarizing multiple aspects of model performance in a single diagram: Journal of Geophysical Research, v. 106, D7, p. 7,183-7,192, accessed at https://doi. org/10.1029/2000JD900719.

Taylor, K.E., Stouffer, R.J., and Meehl, G.A., 2012, An overview of CMIP5 and the experiment design: Bulletin of the American Meteorological Society, v. 93, p. 485-498.

Tracey, J.I., Jr., Schlanger, S.O., Stark, J.T., Doan, D.B., and May, H.G., 1964, General geology of Guam: U.S. Geological Survey Professional Paper 403-A, 104 p., 3 pl., accessed at https://doi. org/10.3133/pp403A.
U.S. Environmental Protection Agency, 2016, Ugum surface water treatment plant, Talofofo, Guam: EPA Factsheet for National Pollutant Discharge Elimination System, July 8, 2016, 21 p., accessed at https://19january2017snapshot.epa.gov/www3/ region9/water/npdes/pdf/guam/ugum/gu0020371-npdes-permitugum-factsheet-2016-07-08.pdf

U.S. Geological Survey and others, 2015, 2012-2013 U.S. Geological Survey LiDAR - Territory of Guam: Department of Commerce, National Oceanic and Atmospheric Administration, National Ocean Service, Office for Coastal Management; downloadable electronic dataset, accessed December 2015, at https://coast.noaa.gov/digitalcoast/data/.

Vacher, H.L. and Mylroie, J.E., 2002, Eogenetic karst from the perspective of an equivalent porous medium: Carbonates and Evaporites, v. 17, no. 2, p. 182-196.

Vann, D.T., Bendixson, V.M., Roff, D.F., Habana, N.C., Simard, C.A., Schumann, RM., and Jenson, J.W., 2013, Aquifer zones (basal and parabasal water): Water and Environmental Research Institute (WERI), University of Guam, accessed at http://north. hydroguam.net/map-hydrology-basal-and-parabasal.php.

Voss, C.I. and Provost, A.M., 2002 (Version of September 22, 2010), SUTRA, A model for saturated-unsaturated variabledensity ground-water flow with solute or energy transport: U.S. Geological Survey, Water-Resources Investigations Report 02-4231, $291 \mathrm{p}$.

Wahl K.L. and Wahl T.L., 1995, Determining the flow of Comal Springs at New Braunfels, Texas in Proceedings of Texas Water '95, A component conference of the American Society of Civil Engineers International Conference on Water Resources Engineering, 1st, San Antonio, Texas, p. 77-86.

Ward, P.E., Hoffard, S.H., and Davis, D.A., 1965, Hydrology of Guam: U.S. Geological Survey Professional Paper 403-H, $28 \mathrm{p} ., 1 \mathrm{pl}$.

Widlansky, M.J, Annamalai, H., Gingerich, S.B., Storlazzi, C.D., Marra, J.J., Hodges, K.J., Choy, B., and Kitoh, A., 2018, Tropical cyclone projections - Changing climate threats for Pacific Island defense installations: American Meteorological Society, Weather, Climate and Society, v. 11, p. 3-15, accessed at https://doi.org/10.1175/WCAS-D-17-0112.1.

Zhang, C., 2016, Dynamical Downscaled and Projected Climate for the Pacific Islands/Guam: Center for Integrated Data Analytics, accessed at https://cida.usgs.gov/thredds/catalog. $\mathrm{html}$ ?dataset=cida.usgs.gov/guam 


\section{Appendixes 1-3}




\section{Appendix 1. Guam Water-Budget Models Used to Estimate Recharge}

Recharge and other water-budget components for the historic and future periods were computed using the two water-budget models (Johnson, 2012) that simulate two modes of recharge: "vadose percolation" and "vadose fast flow," as defined by Jocson and others (2002). Vadose percolation refers to recharge from water that infiltrates slowly to the water table through small pore spaces in the soil, epikarst, and bedrock. Vadose fast flow refers to recharge from water that infiltrates rapidly through large, open pathways, such as caves. Recent companion studies have provided additional evidence supporting this understanding of recharge mechanisms (Bautista, 2017; Shalilian, 2017). As described in the "Fast Flow" section of Johnson (2012), the first Guam model (representing vadose percolation) is nearly identical to the second Guam model (representing vadose fast flow), differing only in the order in which evapotranspiration and recharge are included in the budget.

Johnson (2012) divided the model domain for Guam into 138,408 subareas to estimate recharge for the 1961-2005 period. The two models each calculated 10 water-budget components for each subarea (daily rainfall, irrigation, septic leachate, runoff, captured stormwater, actual evapotranspiration [ET], net precipitation, forest-canopy evaporation, water-main leakage, and recharge). Recharge estimates for the two periods in the current study (1990-2009 and 2080-99) divided the model domain into 172,754 subareas to include the grid-cell boundaries $(0.5-\mathrm{mi}$ resolution) of the Weather Research and Forecasting (WRF) model grid cells (Zhang, 2016). The land area was assumed to remain constant between these two periods, although future sea-level rise could reduce the island area slightly.

\section{Iteration}

At the start of the Guam water-budget models' simulations for both scenarios, each subarea's initial soil-moisture storage was arbitrarily set at 50 percent of its soil-moisture storage capacity, the same as that used by Johnson (2012). To mitigate possible effects of this arbitrary starting value as well as possible effects introduced by the models' random selection of monthly sets of daily rainfall fragments (see Rainfall section below), each of the Guam models was run for 10 simulations, and then the results from each model's simulations were averaged separately. Ten simulations were used for both scenarios (1990-2009 and 2080-99) for consistency with the number of simulations used in the scenarios described in Johnson (2012).

\section{Averaging the Results of the Two Guam Water- Budget Models}

Results from the two water-budget models differed for two water-budget components only: actual ET and recharge. For areas underlain by limestone, it was assumed that 67 percent of recharge originated from vadose percolation and 33 percent of recharge originated from vadose fast flow, on the basis of the groundwater-modeling analysis of Contractor and Jenson (2000). For areas not underlain by limestone, actual ET and recharge were derived from the first Guam water-budget model only. Results from the two water-budget models for these two components were averaged using the same approach as Johnson (2012). Actual ET for subareas underlain by limestone (see fig. 1 of Johnson, 2012) was computed as the sum of 33 percent of actual ET calculated by the first Guam water-budget model and 67 percent of actual ET calculated by the second Guam water-budget model. Recharge was computed as the sum of 67 percent of recharge from the first Guam water-budget model and 33 percent of recharge from the second Guam water-budget model.

\section{Captured Stormwater and its Allocation to Runoff or Recharge}

Captured stormwater represents rain on impervious surfaces that was captured by storm-drain systems. Captured stormwater was included in subareas that were within stormdrain zones 1, 2 or 3, as shown in figure 9 of Johnson (2012) and had "urban builtup" or "urban cultivated" land-cover designations (see Soil and Land-Cover Conditions section below). In the Guam water-budget models' calculations, the rainfall-retention capacity of all impervious surfaces was assumed to be $0.635 \mathrm{~cm}$, and that retained water could evaporate or be stored until the following day. Rain more than $0.635 \mathrm{~cm}$ was considered "excess water." For each relevant subarea, half of the excess water from impervious surfaces was added to the pervious fraction of the subarea, and the remaining excess water was assumed to be captured by a storm-drain system and was considered captured stormwater; the same assumption was made by Johnson (2012). For subareas with an impervious-fraction value greater than 0 but outside of stormdrain zones 1,2 or 3 , excess water from the impervious surfaces was added to the pervious fraction of the subarea.

Captured stormwater was allocated to either runoff or recharge using the approach of Johnson (2012). In storm-drain zone 1, each subarea's captured stormwater was added to its runoff total because the captured stormwater was assumed to be routed to the ocean by way of storm drains or other drainage networks. In storm-drain zone 2, captured stormwater was assumed to be disposed into drywells, and thus was allocated to recharge as follows. In the north part of storm-drain zone 2 near Andersen Air Force Base (see fig. 1) linear rates (that is annual water depths) of captured stormwater were converted to volumetric rates, the sum of which was uniformly distributed as recharge to all subareas in the north part of storm-drain zone 2 without the "urban-builtup" land-cover designation. Similarly, in the south part of storm-drain zone 2 near Antonio B. Won Pat International Airport, linear rates of captured stormwater were converted to volumetric rates, the 
sum of which was uniformly distributed as recharge to all subareas in the south part of storm-drain zone 2 without the "urban-builtup" land-cover designation. In storm-drain zone 3, linear rates of captured stormwater values were converted to volumetric rates, the sum of which was uniformly distributed as recharge to all subareas within the area designated as the Harmon Sink, a stormwater disposal pit [see fig. 9 in Johnson, 2012].

\section{Water-Budget Model Inputs for 1990-2009 Scenario}

One set of water-budget model input files was prepared for the 1990-2009 scenario and was used in both Guam water-budget models. Model inputs used to simulate soil and land-cover conditions, irrigation, septic-leachate, and watermain leakage were the same as those used in the 1961-2005 scenario described in Johnson (2012). New model inputs were developed to simulate rainfall, the relation of runoff-torainfall, and reference ET.

\section{Soil and Land-Cover Conditions}

Each subarea was assigned time invariant soil type and land-cover designation. Soil types varied spatially and were assigned the same available-water-capacity values that were used by Johnson (2012). Land-cover designations also varied spatially, as shown in fig. 4 of Johnson (2012). The land-cover designation assigned to each subarea was used to assign four additional time invariant input parameters (pervious fraction, crop coefficient, root depth, and depletion fraction), as shown in table 2 of Johnson (2012).

Only two land-cover classes, "urban builtup" and "urban cultivated," were assigned pervious-fraction values less than 1.00 , meaning subareas with these land-cover designations were assumed to contain impervious surfaces such as roads, buildings, and other paved areas. All remaining land covers were assigned pervious fraction values of 1.00. For all subareas with one of the seven forest land-cover designations, the Guam models computed net precipitation on the basis of daily precipitation (see Rainfall section below), canopystorage capacity (0.035 in), and a daily constant (1.095), as described in Johnson (2012). Forest-canopy evaporation was calculated as precipitation minus net precipitation. For all remaining subareas, those without a forest land-cover designation, net precipitation equaled precipitation, and forest canopy evaporation was set to zero in results of the Guam water-budget models. For subareas with the "water" land-cover designation, recharge was set at $12 \mathrm{in} / \mathrm{yr}$, and actual evapotranspiration was computed by the models as the difference of precipitation and runoff minus $12 \mathrm{in.} \mathrm{None} \mathrm{of}$ these subareas had water-main leakage or septic leachate. This approach also was used by Johnson (2012).

\section{Rainfall}

Water-budget model inputs for rainfall consisted of mean monthly rainfall distribution for 1990-2009, annual rainfall weighting factors, and monthly sets of daily rainfall fragments. Precipitation equaled rainfall for all subareas because fog interception was assumed negligible for all parts of Guam, the same assumption used by Johnson (2012). The Guam waterbudget models synthesized daily rainfall for each subarea as the product of monthly rainfall and a daily rainfall fragment (each daily rainfall fragment represents the fraction of the monthly rainfall that occurred on that day), ranging from 0 to 1, as described in Johnson (2012). Monthly rainfall values for each year during 1990-2009 were computed in the models as the product of mean monthly rainfall values for 1990-2009 and an annual rainfall weighting factor. Monthly sets of daily rainfall fragments were assigned to each of the 18 Thiessen polygons shown in figure 2 of Johnson (2012). For a given subarea, the set of daily rainfall fragments used for a given month was selected randomly by the Guam water-budget models from among all available sets for the month and for the Thiessen polygon containing the subarea.

Maps of mean monthly rainfall for 1990-2009 were not available for Guam. Previously, Johnson (2012) assigned each subarea a mean monthly rainfall value for 1971-2000 using the mean monthly rainfall maps of Daly and Halbleib (2006). For our analysis, 1990-2009 mean monthly rainfall for each subarea was estimated as the product of its 1971-2000 mean monthly rainfall value and a mean monthly rainfall-adjustment factor. Examination of available rainfall data obtained from the National Climatic Data Center (https://www.ncdc.noaa. gov) indicated that the station located at the Antonio B. Won Pat International Airport (see station labeled 226 in fig. 2 of Johnson, 2012) was the only station on Guam with complete rainfall records during 1990-2009. Therefore, rainfall records from this station were selected to compute one set of mean monthly rainfall-adjustment factors that was assigned to all subareas. Using the selected rainfall records, each of the following rainfall-adjustment factors was computed as the ratio of mean monthly rainfall during 1990-2009 to mean monthly rainfall during 1971-2000: 0.952 (January), 0.866 (February), 0.625 (March), 0.772 (April), 0.656 (May), 1.238 (June), 1.052 (July), 1.120 (August), 1.023 (September), 0.932 (October), 1.031 (November), and 1.132 (December).

Using the same approach as Johnson (2012), rainfall records from the station located at the Antonio B. Won Pat International Airport also were used to compute one set of 20 annual rainfall-weighting factors for 1990-2009 (table 1.1). Each annual rainfall-weighting factor for a given year during 1990-2009 equaled the ratio of annual rainfall for the year to mean annual rainfall for 1990-2009. The annual rainfallweighting factors were applied to all subareas in the Guam water-budget models' calculations. 
Table 1.1 Annual weighting factors used to simulate interannual variability of rainfall and reference evapotranspiration (ET) in the Guam water-budget models for historic and future conditions

\begin{tabular}{cccccc}
\hline Year & Historic rainfall & Historic reference ET & Year & Future rainfall & Future reference ET \\
\hline 1990 & 1.223 & 1.013 & 2080 & 1.056 & 0.992 \\
1991 & 1.033 & 1.038 & 2081 & 0.939 & 1.000 \\
1992 & 1.096 & 0.996 & 2082 & 0.715 & 1.001 \\
1993 & 0.700 & 1.003 & 2083 & 0.786 & 0.985 \\
1994 & 0.961 & 0.947 & 2084 & 1.472 & 0.984 \\
1995 & 0.945 & 0.931 & 2085 & 0.599 & 1.016 \\
1996 & 1.165 & 0.933 & 2086 & 0.719 & 1.008 \\
1997 & 1.309 & 0.941 & 2087 & 1.078 & 1.002 \\
1998 & 0.575 & 1.029 & 2088 & 0.499 & 1.035 \\
1999 & 0.864 & 0.937 & 2089 & 0.865 & 1.010 \\
2000 & 0.879 & 0.969 & 2090 & 0.837 & 1.016 \\
2001 & 1.023 & 0.990 & 2091 & 0.796 & 1.013 \\
2002 & 1.378 & 0.975 & 2092 & 0.932 & 0.996 \\
2003 & 1.116 & 1.000 & 2093 & 1.704 & 0.987 \\
2004 & 1.385 & 0.964 & 2094 & 1.427 & 0.976 \\
2005 & 0.886 & 1.040 & 2095 & 0.968 & 0.995 \\
2006 & 0.893 & 1.082 & 2096 & 1.312 & 0.986 \\
2007 & 0.875 & 1.071 & 2097 & 0.738 & 1.013 \\
2008 & 0.729 & 1.080 & 2098 & 1.072 & 0.998 \\
2009 & 0.965 & 1.061 & 2099 & 1.486 & 0.987 \\
\hline
\end{tabular}

To compute monthly sets of daily rainfall fragments, daily-rainfall records from stations on Guam were obtained from the National Climatic Data Center and from the USGS at https://waterdata.usgs.gov/nwis. Next, records from 14 stations were selected on the basis of location and record completeness during 1990-2009. Locations of the 14 selected stations are shown in figure 2 of Johnson (2012) with identification numbers of $001,025,156,226,275,229,468,727,950$, 131105144405166, 131729144393766, 132132144422366, 132264144441966, and 132617144423366. The four additional stations used by Johnson (2012), shown with identification numbers of 193, 278, 827, and 133209144545301, were excluded from the analysis because their rainfall records were less than 20 percent complete during 1990-2009 and because nearby stations had more complete records during 1990-2009. Next, the daily rainfall records for the selected stations and the method described in Johnson (2012) were used to compute monthly sets of daily rainfall fragments. Fragment sets for each selected station were assigned to the station's Thiessen polygon shown in figure 2 of Johnson (2012). Fragment sets for stations $132132144422366,275,727$, and 950 also were assigned to the nearby Thiessen polygons of stations 193, 278, 827, and 133209144545301, respectively.

\section{Irrigation}

Irrigation was estimated using the same approach as Johnson (2012). For subareas with the "Agricultural field" land-cover designation, daily irrigation was computed on the basis of rainfall and potential evapotranspiration, using equation 1 , for all months of the year. For subareas with the "Golf course" land-cover designation, daily irrigation was (1) computed using equation 1 for January through June only, and (2) assumed to be zero for July through December; Johnson (2012) made the same assumption after discussions with golf-course maintenance personnel on Guam. For all remaining subareas, irrigation was zero for all months.

$$
\begin{gathered}
(P E)_{m}-P_{m}>0, I_{m}=\left((P E)_{m}-P_{m}\right) / d_{m}, \text { and } \\
(P E)_{m}-P_{m} \leq 0, I_{m}=0,
\end{gathered}
$$

where

$$
\begin{aligned}
& I_{m} \quad \text { is the amount of daily irrigation for month } m[\mathrm{~L}] \text {, } \\
& P_{m} \quad \text { is the amount of rainfall for month } m[\mathrm{~L}] \text {, } \\
& (P E)_{m} \quad \text { is the potential evapotranspiration for month } m \\
& \text { (varies by land cover) [L], and } \\
& d_{m} \quad \text { is the number of days in month } m \\
& \text { [dimensionless]. }
\end{aligned}
$$




\section{Septic Leachate}

The spatial distribution and rates of septic leachate were the same as those used in the 1961-2005 scenario described in Johnson (2012). Johnson (2012) used geospatial datasets provided by the Water and Environmental Research Institute of the Western Pacific (WERI) and GWA to create a geospatial dataset of about 15,000 points representing households assumed to use onsite wastewater disposal systems. A map of leachfield areas that receive wastewater was generated by creating a 750 square-feet circular area around each of these points. In the Guam water-budget models' calculations, a constant septicleachate rate of $0.7 \mathrm{in} / \mathrm{d}$ was used for each subarea within the leach-field areas. Septic leachate was assumed to enter the soil at depths where it was subject to evapotranspiration.

\section{Water-Main Leakage}

The spatial distribution and rates of water-main leakage were the same as those used in the 1961-2005 water-budget scenario described in Johnson (2012). For subareas with water-main leakage, leakage rates were time invariant, but varied spatially, ranging from 0.1 to $0.86 \mathrm{in} / \mathrm{d}$. Unlike septic leachate, water-main leakage was assumed to enter the soil at depths where it was not subject to ET.

\section{Runoff}

To compute runoff in the Guam water-budget models, subareas were grouped into the runoff regions shown in figure 8 of Johnson (2012). In all runoff regions other than regions 1 and 11 , the models computed daily runoff for a given subarea as the product of daily rainfall and the region's assigned mean monthly runoff-to-rainfall (RR) ratio for the corresponding month (table 1.2). Methods used to estimate each region's mean monthly $\mathrm{RR}$ ratios are described next.

Using the same approach as Johnson (2012), runoff regions 1 and 11 were assigned mean monthly RR ratios of zero. Runoff region 1 consisted of subareas where runoff to the ocean from all surfaces was assumed negligible. In runoff region 11, runoff from pervious surfaces also was assumed negligible, but runoff from impervious surfaces was accounted for using estimates of captured stormwater, as described earlier in the Captured Stormwater and its Allocation to Runoff or Recharge section.

For all remaining runoff regions, mainly in southern Guam, mean monthly RR ratios used for 1990-2009 were greater than zero (table 1.2) and were estimated using the same method that Johnson (2012) used to estimate RR ratios for 1971-2000. Daily streamflow records were obtained for 13 USGS stream-gaging stations (table 1.2) and the following process was followed:

1. For each streamflow record, daily runoff values were estimated using the hydrograph-separation program of Wahl and Wahl (1995), as described in Johnson (2012). Values of $\mathrm{N}$ (number of days) and $\mathrm{f}$ (turning point test factor) in the hydrograph-separation program were respectively set to 4 and 0.9 for all stream-gaging stations.

2. Daily runoff values were summed into monthly values for each gaging station.

3. Three stream-gaging stations $(16847000,16848500$, and 16858000) were selected as index stations to use for adjusting all mean monthly runoff values to 1990-2009 for the remaining 10 stations. Previously, Johnson (2012) selected the same three stations to use as index stations. Runoff records for the index stations were nearly complete during 1990-2009, and their few missing runoff values were estimated using the methods described in Johnson (2012).

4. For each index station, mean monthly RR ratios for 1990-2009 were computed as the ratio of its mean monthly runoff values for 1990-2009 to mean monthly rainfall for 1990-2009 averaged over its drainage basin.

5. One index station was assigned to each of the 10 non-index stations (table 1.2), using the same assignments as Johnson (2012).

6. For each non-index station, mean monthly direct runoff was calculated for the non-index station and for the assigned index station for an overlapping period when both stations were concurrently measuring streamflow (see "Period of record used in calculation" column in table 3 of Johnson, 2012).

7. For the assigned index station, mean monthly runoff during 1990-2009 was divided by mean monthly runoff during the overlapping period, resulting in 12 mean monthly runoffadjustment factors. Each mean monthly runoff value for the non-index station during the overlapping period was multiplied by the appropriate runoff-adjustment factor to compute 12 adjusted mean monthly runoff values.

8. For each non-index station, mean monthly RR ratios for 1990-2009 were computed as the quotient of (1) its adjusted mean monthly runoff values, and (2) mean monthly rainfall values for 1990-2009 averaged over its drainage basin.

9. The 1990-2009 mean monthly RR ratios for the 13 stations were used to assign ratios to each runoff region, using the same methods as Johnson (2012) and shown in table 1.2.

\section{Reference ET}

Reference ET, as defined for our analysis, is the ET rate of a hypothetical grass surface completely shading the ground, of uniform height, and optimum soil-water conditions for given climatic conditions. In previous water-budget simulations for Guam, Johnson (2012) assumed that reference ET was spatially uniform over the domain of the Guam water-budget models. The same assumption was made for the 1990-2009 scenario because complete records of climate data needed to compute reference 
Table 1.2. Mean monthly runoff-to-rainfall ratios assigned to runoff regions for the Guam water-budget models for the 1990-2009 scenario.

[See figure 8 in Johnson (2012) for locations of runoff regions. All station numbers are those of U.S. Geological Survey stream-gaging stations. - indicates that no index station was assigned]

\begin{tabular}{|c|c|c|c|c|c|c|c|c|c|c|c|c|c|c|}
\hline \multirow{2}{*}{$\begin{array}{l}\text { Runoff } \\
\text { region }\end{array}$} & \multicolumn{12}{|c|}{ Ratio of runoff to rainfall, adjusted to $1990-2009$} & \multirow{2}{*}{$\begin{array}{l}\text { Method used to calculate } \\
\text { runoff-to- rainfall ratios }\end{array}$} & \multirow{2}{*}{$\begin{array}{l}\text { Assigned } \\
\text { index station }\end{array}$} \\
\hline & Jan. & Feb. & Mar. & Apr. & May & June & July & Aug. & Sept. & Oct. & Nov. & Dec. & & \\
\hline 1 & 0.000 & 0.000 & 0.000 & 000 & .000 & .000 & 0.000 & .000 & 0.000 & 0.000 & 0.000 & 000 & Assume runoff is zero & - \\
\hline $2 \mathrm{a}$ & 0.189 & 0.198 & 0.071 & 0.037 & 0.124 & 0.052 & 0.202 & 0.435 & 0.411 & 0.409 & 0.508 & 0.384 & Station 16865000 & 16858000 \\
\hline $2 b$ & 0.197 & 0.140 & 0.057 & 0.037 & 0.093 & 0.046 & 0.167 & 0.348 & 0.333 & 0.323 & 0.400 & 0.332 & Station $16858000 \mathrm{~A}$ & - \\
\hline $2 \mathrm{c}$ & 0.193 & 0.169 & .064 & 0.037 & 0.109 & 0.049 & 0.185 & 392 & 0.372 & 0.366 & 0.454 & 0.358 & Average of runoff regions $2 \mathrm{a}$ an & - \\
\hline $3 a$ & 0.117 & 0.153 & 0.040 & 0.025 & 0.077 & 0.214 & 0.217 & 0.374 & 0.349 & 0.159 & 0.394 & 0.197 & Station 16807650 & 16847000 \\
\hline $3 b$ & 0.151 & 0.114 & 0.117 & 0.050 & 0.158 & 0.130 & 0.142 & 0.235 & 0.233 & 0.240 & 0.237 & 0.255 & Station 16808300 & 16848500 \\
\hline $3 \mathrm{c}$ & 0.134 & 0.134 & 0.079 & 0.038 & 0.118 & 0.172 & 0.180 & 0.305 & 0.291 & 0.200 & 0.316 & 0.226 & Average of runoff regions $3 a$ and $3 b$ & - \\
\hline 4 & 0.183 & 0.143 & 0.061 & 0.038 & 0.089 & 0.046 & 0.194 & 0.420 & 0.433 & 0.339 & 0.384 & 0.391 & Station 16845000 & 16858000 \\
\hline $5 \mathrm{a}$ & 0.169 & 0.146 & 0.065 & 0.065 & 0.093 & 0.185 & 0.150 & 0.326 & 0.300 & 0.273 & 0.303 & 0.339 & $16848500 \mathrm{~A}$ & - \\
\hline $5 b$ & 0.190 & 0.159 & 0.036 & 0.038 & 0.053 & 0.266 & 0.171 & 0.340 & 0.256 & 0.245 & 0.314 & 0.185 & Station $16847000 \mathrm{~A}$ & - \\
\hline $5 \mathrm{c}$ & 0.180 & 0.153 & 0.051 & 0.052 & 0.073 & 0.226 & & & 0.278 & 0.259 & 0.309 & 0.262 & Average of runoff regions $5 \mathrm{a}$ and $5 \mathrm{~b}$ & - \\
\hline 6 & 0.162 & 0.155 & 0.027 & 0.024 & 0.044 & 0.182 & 0.130 & 0.203 & 0.143 & 0.178 & 0.172 & 0.129 & Station 16855000 & 16847000 \\
\hline 7 & 0.147 & 0.124 & 0.025 & 0.027 & 0.056 & 0.141 & 0.1 & 0.249 & 0.177 & 0.201 & 0.181 & & Station 16840000 & 16847000 \\
\hline 8 & 0.209 & 0.146 & 0.034 & 0.043 & 0.074 & 0.189 & 0.171 & 0.332 & 0.228 & 0.248 & 0.232 & 0.145 & Station 16835000 & 16847000 \\
\hline $9 a$ & 0.328 & 0.253 & 0.060 & 0.072 & 0.101 & 0.445 & 0.275 & 0.376 & 0.249 & 0.288 & 0.305 & 0.269 & Station 16809400 & 16847000 \\
\hline $9 b$ & 0.223 & 0.211 & 0.068 & 0.052 & 0.145 & 0.219 & 0.219 & 0.380 & 0.289 & 0.276 & 0.378 & 0.186 & Station 16809600 & 16847000 \\
\hline $9 \mathrm{c}$ & 0.199 & 0.150 & 0.044 & 0.043 & 0.072 & 0.162 & 0.205 & 0.310 & 0.224 & 0.266 & 0.251 & 0.199 & Station 16816000 & 16847000 \\
\hline $9 d$ & 0.250 & 0.205 & 0.057 & 0.056 & 0.106 & 0.275 & 0.233 & 0.355 & 0.254 & 0.277 & 0.311 & 0.218 & Average of runoff regions $9 a, 9 b$, and $9 c$ & - \\
\hline 10 & 0.147 & 0.124 & 0.025 & 0.027 & 0.056 & 0.141 & 0.117 & 0.249 & 0.177 & 0.201 & 0.181 & 0.111 & Assume same as runoff region 7 & - \\
\hline 11 & 0.000 & 0.000 & 0.000 & 0.000 & 0.000 & 0.000 & 0.000 & 0.000 & 0.000 & 0.000 & 0.000 & 0.000 & Runoff accounted for separately & - \\
\hline
\end{tabular}

ET for 1990-2009 were available for one station only, the station located at the Antonio B. Won Pat International Airport.

The Guam water-budget models computed daily reference ET as monthly reference ET divided by the number of days in the month. For a given month during 1990-2009, the models computed monthly reference ET as the product of (1) mean annual reference ET for 1990-2009, (2) an annual reference-ET weighting factor, which represents the ratio of annual reference ET for the year to mean annual reference ET for 1990-2009, and (3) a mean monthly reference-ET weighting factor, which represents the ratio of mean monthly reference ET for 1990-2009 to mean annual reference ET for 1990-2009. The potential ET, the maximum ET rate from the plant-root zone, was computed in the Guam water-budget models by multiplying the reference ET by the subarea's assigned crop coefficient.

Water-budget model inputs used to simulate reference ET during 1990-2009 consisted of (1) mean annual reference ET (67.6 in, table 1.3), (2) one set of 20 annual reference-ET weighting factors (table 1.1), and (3) one set of 12 mean monthly reference-ET weighting factors. Each mean monthly reference-ET weighting factor equaled the ratio of mean monthly reference ET for 1990-2009 (table 1.3) to $67.6 \mathrm{in}$. All three model inputs were derived from 1990-2009 daily reference-ET values that were computed using the method described in Allen and others (1998) and using daily climate records and solar-radiation estimates from the station at the Antonio B. Won Pat International Airport. Daily climate data (minimum air temperature, maximum air temperature, dew point temperature, and mean wind speed) during 1990-2009 were obtained from the National Climatic Data Center at https://gis.ncdc.noaa.gov/maps/ncei/cdo/daily. Daily incoming solar radiation was computed from hourly incoming solarradiation estimates obtained from the 1961-90 and 1991-2010 National Solar Radiation Databases, available at http://rredc.nrel. gov/solar/old_data/nsrdb/.

Table 1.3. Mean monthly reference evapotranspiration values used to create inputs for the Guam water-budget models

\begin{tabular}{lcc}
\hline Month & $\begin{array}{c}\text { Mean reference } \\
\text { evapotranspiration, } \\
\text { 1990-2009, } \\
\text { in inches }\end{array}$ & $\begin{array}{c}\text { Mean reference } \\
\text { evapotranspiration, } \\
\text { 2080-2099, } \\
\text { in inches }\end{array}$ \\
\hline January & 5.37 & 5.80 \\
February & 5.33 & 5.74 \\
March & 6.62 & 7.08 \\
April & 6.61 & 7.16 \\
May & 6.65 & 7.16 \\
June & 6.11 & 6.61 \\
July & 5.62 & 6.08 \\
August & 5.22 & 5.70 \\
September & 4.91 & 5.46 \\
October & 5.07 & 5.49 \\
November & 4.95 & 5.39 \\
December & 5.13 & 5.63 \\
\hline Mean annual & 67.59 & 73.30 \\
\hline
\end{tabular}




\section{Using Modeled Climate Variables to Compute Change Factors for Simulating Rainfall and Reference Evapotranspiration During 2080-99}

Rainfall and reference ET for the future 2080-99 period used inputs for the 1990-2009 period that were modified by mean monthly change factors. Climate variables for 1990 2009 and 2080-99 that were produced by simulations of the WRF-model analysis for Guam (Zhang, 2016) were used to compute change factors (Arnell and Reynard, 1996 and Hay and others, 2000) and prepare rainfall and reference-ET inputs for the Guam water-budget models for the 2080-99 scenario. The change factors represent ratios of WRF-modeled climate conditions for a future period (2080-99) to WRF-modeled climate conditions for a historic period (1990-2009). The change factors were used to modify historic rainfall and reference-ET datasets, and the resulting, modified datasets were used to create rainfall and reference-ET inputs for the Guam water-budget models for the 2080-99 scenario (see Recharge Model Inputs for 2080-2099 Scenario section below). Gingerich and others (2017) also used the changefactor approach to prepare model inputs for simulating future rainfall and reference-ET conditions in a similar water-budget analysis for Roi-Namur, Kwajalein Atoll.

Computation of simulated reference-ET and rainfall values was done in the following manner:

- For each WRF-model grid cell, the selected variables were used to compute simulated hourly reference-ET values for 1990-2009 and for 2080-99. Simulated referenceET values were computed using the method described in Allen and others (1998) and by using separate surfaceresistance values for daytime (50 seconds per meter $[\mathrm{s} / \mathrm{m}]$ ) and nighttime $(200 \mathrm{~s} / \mathrm{m})$, as recommended in Allen and others (2006).

- The simulated hourly reference-ET values were summed into monthly and annual values.

- For each WRF-model grid cell, hourly rainfall values from WRF model datasets were summed into simulated daily rainfall values, which were rounded to the nearest $0.025 \mathrm{~cm}$ (0.01 inch).

- The simulated daily rainfall values for each WRF model grid cell were summed into monthly and annual rainfall values for 1990-2009 and for 2080-99.

The climate variables in the WRF-model datasets were not directly used as model inputs to Guam water-budget models because these variables likely would have required adjustments for biases, and these bias adjustments would require additional efforts that were beyond the scope of our analysis. Instead, by using the change-factor method, the climate variables from the WRF-model simulations were assumed to represent relative changes between 1990-2009 and 2080-99.

\section{Water-Budget Model Inputs for 2080-99 Scenario}

A separate set of model input files was prepared for the 2080-99 scenario and was used in both Guam water-budget models. Model inputs used to simulate soil and land-cover conditions, irrigation, septic-leachate, and water-main leakage were the same as those used in the 1990-2009 scenario. New model inputs were developed to simulate rainfall, the relation of runoff to rainfall, and reference ET.

\section{Rainfall}

Model inputs used to simulate rainfall during 2080-99 consisted of (1) mean monthly rainfall estimates for 2080-99 for each subarea, (2) one set of 20 annual rainfall weighting factors assigned to all subareas, and (3) monthly sets of daily rainfall fragments assigned to each Thiessen polygon shown in figure 2 of Johnson (2012).

For each subarea, mean monthly rainfall for 2080-99 was estimated as the product of its mean monthly rainfall values for 1990-2009 and mean monthly rainfall change factors. Each subarea was assigned one set of mean monthly rainfall change factors from the WRF-model grid cell that encompasses the subarea. The mean monthly rainfall change factors for each WRF-model grid cell were computed as the ratios of simulated mean monthly rainfall for 2080-99 to simulated mean monthly rainfall for 1990-2009 (see Using Modeled Climate Variables to Compute Change Factors for Simulating Rainfall and Reference Evapotranspiration During 2080-99 section above). Mean monthly rainfall change factors assigned to the subareas ranged from 0.528 to 1.814 .

One set of 20 annual future-rainfall weighting factors was used for the 2080-99 scenario (table 1.1). The weighting factors were derived from simulated rainfall values from the WRF model for 2080-99. For each WRF grid cell, simulated rainfall values were converted from depth to volume using the cell's area that overlapped the domain of the Guam models. Each annual rainfall weighting factor was computed as the ratio of Guam's simulated annual rainfall volume for an individual year during 2080-99 to Guam's simulated mean annual rainfall volume for 2080-99.

Monthly sets of daily rainfall fragments for the 2080-99 scenario were derived from "future" daily rainfall records that were modified versions of the historic daily rainfall records used to create the monthly sets of daily rainfall fragments for the 19902009 scenario in the following manner:

To modify the historic records, each Thiessen polygon shown in figure 2 in Johnson (2012) was assigned one set of mean monthly rainfall change factors and one set of mean monthly rain-day change factors. For a given Thiessen polygon, the assigned mean monthly rainfall change factors were computed as the quotient of (1) the average of the simulated 2080-99 mean monthly rainfall values for the WRF-model grid cells overlapping the Thiessen polygon and (2) the average of the simulated 1990-2009 mean monthly rainfall values for the WRF-model grid cells overlapping the Thiessen polygon. 
The same method was used to compute one set of mean monthly rain-day change factors for each Thiessen polygon. Because of the method used to round the simulated daily rainfall values derived from the WRF-model datasets, only days with rain amounts of at least $0.025 \mathrm{~cm}$ were considered rain days, and all remaining days were considered dry days.

For each historic rainfall record that was assigned to a given Thiessen polygon (see Rainfall section above), the method described in the supplemental material of Gingerich and others (2017) was used to compute a record of "future daily rainfall values" based on the polygon's assigned rainfall and rain-day change factors. As described in the supplemental material of Gingerich and others (2017), the method used to compute the future daily rainfall values randomly selects new rain days and new dry days. To mitigate the effects of such random selection, 20 separate future daily rainfall records were created for each historic daily rainfall record.

The future daily rainfall records and the method described in Johnson (2012) were used to compute monthly sets of daily rainfall fragments for each Thiessen polygon for the 2080-99 scenario.

\section{Runoff}

A separate set of mean monthly RR ratios (table 1.4) was used in the Guam water-budget models for the 2080-99 scenario, because the distribution of Guam's mean monthly rainfall for 2080-99 is estimated to be different than the distribution estimated for 1990-2009 (fig. 1.1).

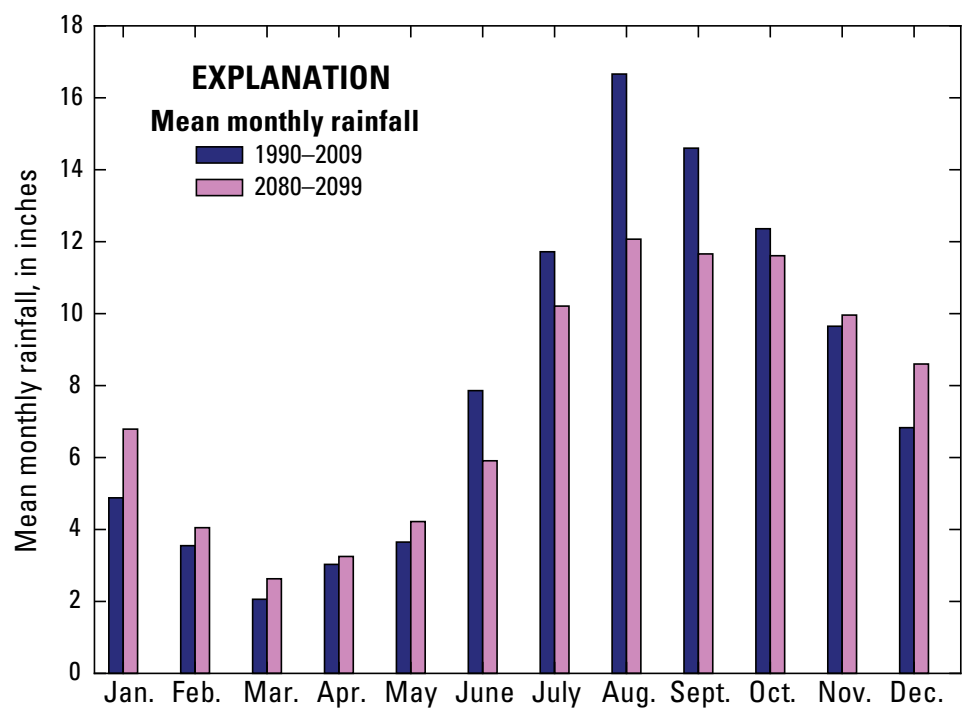

Figure 1.1. Mean monthly rainfall, expressed as uniform depths over the domain of the Guam models for 1990-2009 and 2080-99.

Table 1.4. Mean monthly runoff-to-rainfall ratios assigned to runoff regions of the Guam water-budget models for the 2080-2099 scenario

[See figure 8 in Johnson (2012) for locations of runoff regions]

\begin{tabular}{cccccccccccccc}
\hline \multirow{2}{*}{ Runoff region } & \multicolumn{10}{c}{ Ratio of runoff to rainfall, estimated for 2080-2099 } \\
\cline { 2 - 14 } & Jan. & Feb. & Mar. & Apr. & May & June & July & Aug. & Sept. & Oct. & Nov. & Dec. \\
\hline 1 & 0.000 & 0.000 & 0.000 & 0.000 & 0.000 & 0.000 & 0.000 & 0.000 & 0.000 & 0.000 & 0.000 & 0.000 \\
\hline 2a & 0.206 & 0.188 & 0.065 & 0.032 & 0.111 & 0.038 & 0.143 & 0.374 & 0.356 & 0.325 & 0.498 & 0.425 \\
\hline 2b & 0.237 & 0.154 & 0.054 & 0.030 & 0.086 & 0.035 & 0.140 & 0.273 & 0.263 & 0.284 & 0.396 & 0.363 \\
\hline 2c & 0.241 & 0.207 & 0.067 & 0.031 & 0.106 & 0.036 & 0.139 & 0.279 & 0.259 & 0.261 & 0.416 & 0.400 \\
\hline 3a & 0.136 & 0.163 & 0.037 & 0.024 & 0.080 & 0.190 & 0.193 & 0.275 & 0.294 & 0.138 & 0.394 & 0.211 \\
\hline 3b & 0.183 & 0.118 & 0.102 & 0.048 & 0.147 & 0.103 & 0.099 & 0.158 & 0.180 & 0.176 & 0.161 & 0.219 \\
\hline 3c & 0.163 & 0.153 & 0.080 & 0.040 & 0.118 & 0.145 & 0.146 & 0.226 & 0.214 & 0.152 & 0.287 & 0.241 \\
\hline 4 & 0.236 & 0.150 & 0.058 & 0.034 & 0.093 & 0.036 & 0.161 & 0.330 & 0.373 & 0.249 & 0.363 & 0.432 \\
\hline 5a & 0.194 & 0.166 & 0.068 & 0.056 & 0.088 & 0.124 & 0.114 & 0.224 & 0.204 & 0.212 & 0.263 & 0.350 \\
\hline 5b & 0.232 & 0.199 & 0.038 & 0.038 & 0.055 & 0.218 & 0.142 & 0.242 & 0.196 & 0.205 & 0.288 & 0.193 \\
\hline 5c & 0.201 & 0.177 & 0.053 & 0.049 & 0.076 & 0.184 & 0.136 & 0.238 & 0.193 & 0.206 & 0.272 & 0.263 \\
\hline 6 & 0.200 & 0.192 & 0.027 & 0.022 & 0.047 & 0.153 & 0.105 & 0.151 & 0.101 & 0.132 & 0.163 & 0.136 \\
\hline 7 & 0.184 & 0.160 & 0.030 & 0.027 & 0.054 & 0.115 & 0.092 & 0.172 & 0.132 & 0.169 & 0.172 & 0.121 \\
\hline 8 & 0.245 & 0.180 & 0.042 & 0.042 & 0.065 & 0.156 & 0.142 & 0.259 & 0.192 & 0.232 & 0.226 & 0.156 \\
\hline 9a & 0.405 & 0.304 & 0.057 & 0.064 & 0.067 & 0.361 & 0.205 & 0.230 & 0.195 & 0.270 & 0.293 & 0.280 \\
\hline 9b & 0.265 & 0.252 & 0.072 & 0.050 & 0.118 & 0.186 & 0.167 & 0.246 & 0.226 & 0.259 & 0.375 & 0.193 \\
\hline 9c & 0.226 & 0.186 & 0.040 & 0.038 & 0.054 & 0.131 & 0.133 & 0.200 & 0.191 & 0.263 & 0.254 & 0.206 \\
\hline 9d & 0.320 & 0.280 & 0.074 & 0.054 & 0.089 & 0.238 & 0.180 & 0.206 & 0.192 & 0.244 & 0.305 & 0.233 \\
\hline 10 & 0.183 & 0.151 & 0.026 & 0.026 & 0.056 & 0.118 & 0.097 & 0.179 & 0.134 & 0.157 & 0.169 & 0.119 \\
\hline 11 & 0.000 & 0.000 & 0.000 & 0.000 & 0.000 & 0.000 & 0.000 & 0.000 & 0.000 & 0.000 & 0.000 & 0.000 \\
\hline
\end{tabular}


The monthly RR ratios used for the 2080-99 scenario were estimated as the product of the RR ratios used for the 1990-2009 scenario (table 1.2) and a set of mean RR change factors assigned to each runoff region. Mean monthly RR change factors were estimated using runoff and rainfall results of Precipitation-Runoff Modeling System (PRMS) model simulations for southern Guam for historic and future periods (Rosa, 2017). The PRMS model output of Rosa (2017) included daily results for 317 areas termed hydrologic response units (HRUs) in southern Guam (fig. 3). All HRUs were selected for computing RR change factors except for the HRU representing FVR. Daily PRMS results selected for computing RR change consisted of results for 1990-2009 and 2080-99 for all selected HRUs except those in the Almagosa West, Almagosa, Imong, Maulap, and FVR_ungaged regions (fig. 3), for which results were available for 1998-2009 and 2088-99 only.

The set of RR change factors assigned to each runoff region was determined using the following steps:

1. For each runoff region, the area of each HRU within the region was delineated.

2. The selected PRMS results for the historic periods were used to compute mean monthly runoff in units of depth for each of the selected HRUs. The sum of two PRMS components, surface runoff and interflow, was considered runoff for this analysis.

3. For each area where an HRU overlapped a runoff region, mean monthly runoff volumes for the overlapping area were computed as the product of mean monthly runoff depths for the HRU and the overlap area.

4. The results of the previous step were summed by runoff region and by calendar month to compute mean monthly runoff values for each runoff region for the historic periods.

5. The previous three steps were repeated to compute, for each runoff region, mean monthly rainfall for the historic periods, mean monthly runoff for the future periods, and mean monthly rainfall for the future periods.

6. Results from the previous step were used to compute a set of historic mean monthly RR ratios and a set of future mean monthly RR ratios for each runoff region.

7. For a given runoff region and calendar month, the mean RR change factor was computed as the future mean monthly RR ratio divided by the appropriate historic mean monthly $R R$ ratio.

The estimated change factors ranged from 0.579 to 1.368 for runoff regions 2 through 10 .

\section{Reference ET}

For consistency with the 1990-2009 scenario, reference ET was assumed to be spatially uniform for the 2080-99 scenario. Model inputs used to simulate reference ET during 2080-99 consisted of (1) mean annual reference ET (73.3 in, table 1.3), (2) one set of 12 mean monthly reference-ET weighting factors, and (3) one set of 20 annual reference-ET weighting factors (table 1.1). Each mean monthly reference-ET weighting factor equaled the ratio of mean monthly reference ET for 2080-99 (table 1.3) to 73.3 in. The mean monthly reference-ET values for 2080-99 were computed as the product of mean monthly reference-ET values for 1990-2009 (table 1.3) and one set of mean monthly reference-ET change factors. Each change factor was computed as the ratio of Guam's simulated mean monthly reference ET volume for 2080-99 to Guam's simulated mean monthly reference ET volume for 1990-2009. For each WRF grid cell, simulated reference-ET values were converted from depth to volume using the cell's area that overlapped the domain of the Guam water-budget models. Each annual reference-ET weighting factor was computed as the ratio of Guam's simulated reference ET volume for the year to Guam's simulated mean annual reference ET volume for 2080-99. 


\section{Appendix 2. Storage Capacity 5 Feet Above Spillway, Fena Valley Reservoir, Guam}

The Fena Valley Reservoir, Guam, was surveyed in February 2014 by the U.S. Geological Survey (USGS). At full capacity, the surface area extends 192 acres, and it was determined that the storage capacity below the spillway crest was 6,915 acre-feet. The procedures used to measure the reservoir and calculate the storage capacity are documented in U.S. Geological Survey Scientific Investigations Report 2015-5128 (Marineau and Wright, 2015). The original storage capacity estimated from pre-dam engineering drawings by Frederic R. Harris, Inc. (1949), was reported as 8,365 acre-feet. This indicates a decrease of 1,450 acre-feet of storage (or 17 percent) over the 63-year period of operation.

A possible management scenario to be evaluated includes an estimate of the reservoir storage capacity under the condition of a 5-foot increase in dam and spillway height. This discussion provides that estimate using two different methods. The two estimates provided in this report use indirect methods to calculate the additional storage capacity above the spillway; however, the uncertainty of either estimate could not be readily calculated and thus, a quantification of uncertainty is not provided in this report.

\section{Method 1-Extrapolation of the 2014 Stage- Capacity Curve}

A stage capacity curve at 0.1 -foot intervals was generated from the 2014 bathymetric survey. All elevations in the 2014 survey were referenced to the Guam Vertical Datum of 2004 (GUVD04; Carlson and others, 2009). The curve generally follows a smooth form, and the upper 30 feet (between about 80 feet GUVD04 and the elevation of the spillway crest) can be approximated well by a 4th-order polynomial regression equation (fig. 1). The spillway crest was measured at 110.8 feet GUVD04 during the 2014 survey (Marineau and Wright, 2015). Using the regression equation, the volume was computed for the elevation of 115.8 feet GUVD04, which is 5 feet above the elevation of the spillway as surveyed in 2014. Total storage capacity using this method was estimated to be 7,890 acre-feet (increase of 975 acre-feet over the 2014 storage capacity).

The underlying assumption in this method is that the overall valley shape does not change substantially above and below the spillway elevation; therefore, results using this method are subjected to uncertainty in topographic differences above and below the spillway crest elevation.

\section{Method 2-Topographic Interpolation of 2013 Lidar Data Near Reservoir Shoreline}

The second method uses a 2013 aerial Light Detection and Ranging (lidar) data set (U.S. Geological Survey and others, 2015) to estimate the topography above the spillway elevation around the reservoir. The lidar data were referenced to GUVD04. Bare-earth elevation points (laser penetrates between vegetation and reflects off the ground) and vegetation elevation points (in which the laser reflects off vegetation) are categorized during post-processing. If there are too few bare-earth elevation points in a given grid cell, the land-surface elevation at that grid point is reported as invalid. Dense vegetation along much of the shoreline caused many of the lidar grid points to be invalid (about 50 percent). These invalid grid points generally were spread uniformly between valid grid points, and most distances between valid grid points typically were only about $3-13$ feet. The valid elevation data near the reservoir above the spillway elevation were merged with the 2014 bathymetric data points. Elevation between valid grid points was estimated using a spatial interpolation algorithm to create a continuous surface.

Elevation data from the continuous surface were tabulated in a similar manner as the 2014 bathymetric data to create a stagecapacity curve that extends above the spillway elevation. The volume estimated using this method was 7,967 acre-feet (increase of 1,052 acre-feet over the 2014 storage capacity). There is some uncertainty in this method because the dense vegetation required interpolation between elevation points that were considered valid.

\section{Results}

The two estimates of reservoir capacity at 5 feet above the existing spillway, 7,890 and 7,967 acre-feet, are in good agreement, which provides confidence in the extrapolation method 1 . The results indicate that raising the height of the dam and spillway by 5 feet would increase the total storage capacity by about 14-15 percent over the present (2014) total storage capacity at the existing spillway elevation.

Although there is some uncertainty associated with each method, this uncertainty was not quantified for this report. The results from these two methods agree within 10 percent and may provide a general range in the potential additional capacity gained by a 5 -foot increase in the elevation of spillway and dam.

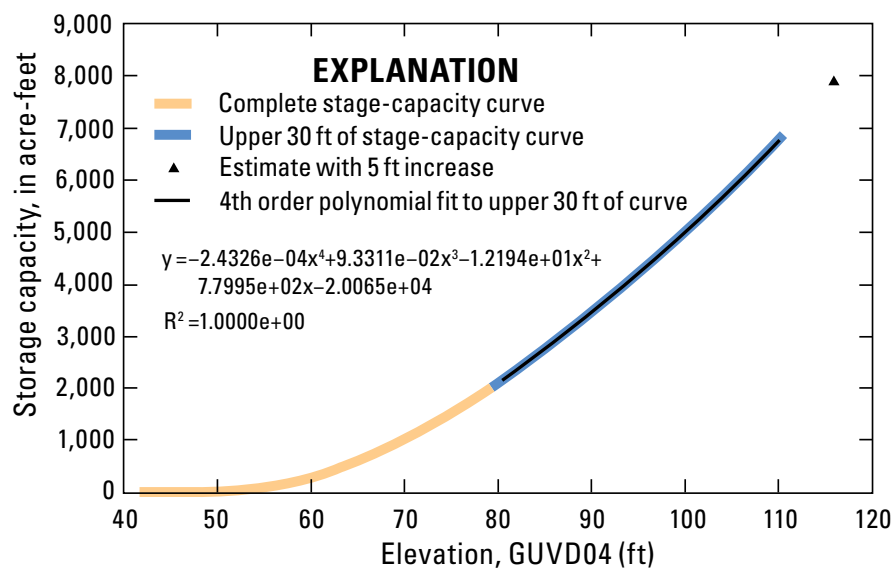

Figure 2.1. Stage-capacity curve generated from the 2014 bathymetric survey of Fena Valley Reservoir, Guam (Marineau and Wright, 2015). A fourth-order polynomial regression equation (black line) generated from the upper 30 feet of the curve was used to extrapolate the capacity at 5 feet above the spillway crest. 


\section{Appendix 3. Stakeholder Outreach and Response}

The overarching goal of stakeholder outreach was to enhance the usefulness of the information generated in this research for individuals responsible for water-resource management. Stakeholder outreach during this study emphasized the iterative development of information deemed most relevant by decision makers managing water resources on Guam. In a series of engagements, the effect of alternative information presentation formats (for example, tabular, graphical, spatial/map-based, range) on decision makers' understanding and use of climate and hydrology information was examined. This outreach approach is well suited for both the resources and political environment in Guam, as it allowed the researchers flexibility in incorporating the dynamic on-the-ground reality of decisions related to water management on the island with desired future outcomes, both technical and policy-based, in the face of a changing climate.

Risk communication and behavioral decision-making research provides a theoretical and methodological framework for understanding how climate science can be used by decision makers to establish management priorities. Several decades of behavioral decision research have demonstrated that the way information is presented affects how it is interpreted and weighted in decisions (for example, Finucane and Gullion [2010] Person-Task Fit Framework; Moser's [2011] Decision Uncertainty Screening Tool; Morgan and others' [2002] Mental Models Framework; Slovic, 1995). Prior work suggests that the use of uncertain information (and its impacts on judgments and decisions) is influenced by characteristics of decision makers, task information, and broader contextual factors. Building on this prior work, stakeholder outreach for this study aimed to explore:

- What are decision makers' perceptions of the utility of alternative information formats in scenarios?

- Which formats of information presentation (for example, tabular, graphical, spatial/map-based, range) affect decision makers perception of their understanding of climate and hydrology information?

\section{Stakeholder Outreach Objectives}

The objectives of the stakeholder assessment and engagement activities were to:

- Conduct initial assessment of key characteristics of the stakeholders, information about climate change and its impacts, and the broader contextual factors influencing understanding of and preferences for alternative management options;

- Examine stakeholders' current use and understanding of climate and hydrology information; and

- Explore stakeholders' perceptions of the usefulness of new information resulting from this project.

\section{Stakeholder Outreach Methods}

\section{Overall Stakeholder Engagement Process}

A selection of stakeholders from multiple relevant sectors were engaged from the beginning of the study to describe familiarity with the research goals and methods, to shape the context of the communication process, and to provide information about the utility of climate and hydrology projections for Guam. Initially through coordination with the Governor of Guam's Climate Change team (through an appointment to the White House's Climate Change Task Force) and existing contacts, engagement was framed by learning about relevant decision challenges for Guam. The integration of military and local government natural resource managers in the engagement process encouraged communication between sectors and allowed each group to learn about how the other makes decisions about natural resources in the face of environmental and socio-political uncertainty.

\section{Workshop}

An initial "kick-off" workshop was held on February 24, 2014, at the Ricardo J. Bordallo Governor's Complex, Adelup, Guam. Attendees included 32 people with a range of backgrounds and interests, such as utilities and energy management, public safety, environmental protection and restoration, environmental compliance, geospatial information technology, water/wastewater engineering, environmental geology, water-resources engineering, water regulation, research and analysis, planning, coastal resources, and government administration. Attendees represented a wide range of federal and local government agencies and nongovernment organizations (table 3.1).

\section{In-depth Interviews}

Three rounds of individual and small-group interviews were held during this study. Round 1 of interviews was aimed at understanding the decision context in which new information from this study could be used. Interviews occurred at the beginning of the project in February 2014 and included 16 people representing high-level decision makers at Naval Facilities (Marianas or Pacific) (NAVFAC), Guam EPA, Guam Department of Public Works (DPW), GWA, the Office of Lieutenant Governor Ray Tenorio, and the Guam Legislature. A semi-structured interview protocol (see below) guided discussions with interviewees to identify their main responsibilities and duties, specify key decisions affected by climate variables now and in the future, determine their current understanding of climate impacts and use of climate information, and identify their climate information needs.

Round 2 of interviews was aimed to explore freshwater managers' background knowledge of climate information and how it is used, and to examine the usability of existing and new 
Table 3.1. Organizations and agencies represented at the February 2014 Guam workshop.

\begin{tabular}{l}
\hline \multicolumn{1}{c}{ Entity } \\
\hline Naval Facilities (NAVFAC) Marianas \\
Naval Facilities (NAVFAC) Andersen Air Force Base \\
U.S. Air Force \\
Office of Lieutenant Governor Ray Tenorio \\
Water and Environmental Research Institute of the Western \\
Pacific, University of Guam (WERI) \\
Office of Senator Thomas Ada \\
Office of Senator Frank B. Agnon \\
Guam Waterworks Authority (GWA) \\
U.S. Environmental Protection Agency (USEPA) Guam \\
Environmental Protection Agency (GEPA) Guam \\
Department of Public Works (Guam DPW) Guam \\
Department of Parks and Recreation \\
Guam Bureau of Statistics and Plans \\
Guam Coastal Management Plan \\
NOAA Coral Program
\end{tabular}

information about climate impacts on Guam's water resources. The first part of the interview focused on assessing respondents' familiarity with some of the reports that are currently available and how they are used. In the second part of the interview, respondents' understanding of various kinds of published displays (maps, graphs, and tables) of climate and water information was assessed. Qualitative thematic analyses of the transcripts were conducted. Semi-structured interviews were conducted in person or via telephone during April-July 2015 with 12 individuals (4 women, 8 men) responsible for managing water resources in Guam. Participating organizations included: NAVFAC Marianas, NAVFAC Pacific, Guam EPA, WERI, GWA, Guam Economic Development Agency, Guam DPW, Guam Climate Change Task Force, Guam Governor's Office, Guam Power Authority, and the Consolidated Commission on Utilities. Participants' professions included management, planning, water/wastewater compliance, and regulations analysis. Ten respondents, for whom demographics were recorded, reported being in their professions about 23 years on average and about 9 years in their current position. Seventy percent had more than a 4-year college degree; no respondents had less than a 4-year college degree. In regard to the ethnicity, 30 percent of respondents reported being mixed race, 50 percent were at least part Guamanian/Chamorro, 20 percent were Filipino, and 50 percent were at least part Caucasian.

Round 3 of interviews aimed to assess perceptions of the usefulness of new climate and hydrology information generated from the study. These interviews occurred at the end of the study in March 2018 and included 13 individuals (4 women, $9 \mathrm{men}$ ) responsible for managing water resources in Guam. Participants' professions represented management, planning and policy making, engineering, and water/wastewater supply, quality, and compliance. Participating organizations included: NAVFAC Marianas, GWA, Guam Governor's Office, Guam Power Authority, Consolidated Commission on Utilities, GEPA, and USEPA.
A semi-structured interview protocol was used to assess perceptions of the usefulness of new results from the results presented at an American Waterworks Association conference held in Guam during March 2018. All interviewees attended the conference presentations or were provided with a synopsis of the presentations before being interviewed.

\section{Stakeholder Outreach Results and Discussion}

Several key themes emerged from the interviews. Each of these themes and related findings are described in more detail below.

Engagement with scientists viewed as valuable - In general, interviewees were appreciative of previous work by USGS and enthusiastic about engaging in future work. Interviewees were particularly interested in learning about the influence of climate change on Guam's water resources and receiving support related to various water-management and communication strategies.

Decisions that would benefit from climate projections are diverse-Interviewees identified many types of watermanagement decisions for which information about future climate conditions would be useful (table 3.2).

Existing resources vary in familiarity and perceived usefulness-Existing resources, such as the USGS report "The Effects of Withdrawals and Drought on Groundwater Availability in the Northern Guam Lens Aquifer, Guam," (Gingerich, 2013) were perceived as familiar and useful to decision makers. Respondents indicated a variety of uses for this report. Some suggested the report is helpful for increasing knowledge or getting "a feel for what's going on." This increased knowledge was useful for briefing leaders in respondents' organizations and providing input for discussions about managing Guam water resources, particularly regarding how to redistribute pumping to minimize salinity. Other ways in which the report's scientific information is used includes: making presentations to others, citing information in another report, and using the information to justify another planning decision. Maps were considered the most useful way to display information, particularly if they reflect island-wide information so that water uses can be coordinated broadly. Information in tables is considered valuable for verifying that correct information has been used in the modeling.

Some respondents suggested that the report should be used in conjunction with other documents, such as Guam's wellhead protection plan, especially when making development and planning (land use) decisions that might affect vulnerable areas. Comparative information is believed particularly valuable for decision makers. Respondents suggested that information is most useful when it allows comparison of the effects of existing pumping conditions on well salinity for alternative future climate conditions (including drought) and land-use conditions (including military buildup). Such comparisons allow planners to explore future pumping scenarios that could minimize effects of greater demand or reduced supply. 
Table 3.2. Examples of climate-sensitive decisions relevant to different Guam agencies and organizations.

\begin{tabular}{|c|c|}
\hline Agency & Example Decision \\
\hline GEPA & $\begin{array}{l}\text { Managing erosion and stabilizing soil: what plants to use and where to put them? } \\
\text { Reducing turbidity in streams that provide intake for water-treatment plants so that they do not shut down when there are } \\
\text { sudden, heavy rains during the wet season } \\
\text { Ensuring sufficient water supply with an acceptable chloride level during dry season } \\
\text { Deploying sediment socks (biodegradable netting to shore up river banks) } \\
\text { Estimating when } 20 \text { - or } 50 \text {-yr flooding events may occur } \\
\text { Limiting sewage overflow } \\
\text { Evaluating how climate change may impact the water-collection system } \\
\text { Evaluating how climate-change may impact stormwater ponding basins that have injection wells }\end{array}$ \\
\hline $\begin{array}{c}\text { NAVFAC, } \\
\text { GWA }\end{array}$ & Distributing clean water \\
\hline DPW & $\begin{array}{l}\text { Sizing culverts needed to divert water under future climate conditions } \\
\text { Evaluating how impervious surfaces (from development) may impact the stormwater collection system } \\
\text { Determining when to clean up debris in the watershed so it doesn't wash into the collection system when heavy rains come }\end{array}$ \\
\hline
\end{tabular}

Climate information is more difficult to understand than hydrological information and should be tied to actionsRespondents had most difficulty interpreting information about typhoon track figures and in integrating information about historical and future projected numbers of typhoons. In particular, confusion persisted about which storm tracks are considered "near" to Guam. Some found it difficult to see subtle differences in the shades of blue used to indicate average annual number of storms and typhoons, suggesting that alternative textures would be easier to interpret.

Information about probability distribution functions seemed hardest for interviewees to understand. Some were unsure of the meaning of the height of the gray bars (observations) and suggested that it would be more easily understood if the bars were related more explicitly to the blue line (historical simulation) and associated management actions implied.

Preferred information format depends on intended use and audience-As evidenced by respondents' range in familiarity with and ability to use climate and water information, decision makers have a wide range in background technical knowledge. Some need more time than others to study a graph to glean relevant information. Importantly, some may have the technical knowledge but do not have the time due to competing demands and multiple responsibilities they are managing as part of their leadership positions. Some respondents noted that decision makers are often multitasking, so scientists need to explain information simply with words (rather than numbers) in a very short time. One respondent emphasized that scientists need to be more "consumer centric" and to interpret the bottom line of the report for decision makers.
In general, respondents suggested that for a general population, figures such as maps and charts (when done right) are easy to elicit information from, whereas tables of data are not as easy. They noted that while not everyone has a good understanding of a map, understanding can be improved with recognizable landmarks (for example, local gas station, funeral home) from which they can compare other land uses. This information may provide perspective that may be valuable for both members of the public and resource managers in government and non-government agencies.

Stakeholders had suggestions for improving the usefulness of climate and water information - Several general issues could be addressed on the basis of respondents' insights revealed during the interviews to improve the usefulness of climate and water information for water managers in Guam:

- Conduct basic training on the issue of climate change (immediacy, experiences of neighboring island communities, and actions to be taken) and how to interpret climate information.

- Create synthesis documents that are short and from a trusted source.

- Provide executive summaries of climate projections and implications for water resource management that are no longer than two pages, in bullet format, and as selfexplanatory as possible.

- Test messages to ensure intended meaning is being conveyed to specific audiences.

- Ensure information (for example, basin boundaries) is consistent across different reports. 
- Establish relationships between scientists and decision makers and build trust and knowledge over time.

Bidirectional communications in working group meetings along the way as research is being done and reports are being developed helps to improve readers' understanding when the final figures are produced because decision makers do not have to sit and study it in detail.

In addition, several improvements were suggested to improve how climate and water information is presented:

- Use different symbols or textures instead of shades of one color (especially important for government agencies without color printers).

- Ensure that when using symbol size to convey variation, the different sizes can be distinguished by the reader.

- Zoom in on Guam (and a little south and east) when presenting storm tracks because that is the most pertinent information for Guam decision makers.

- Provide comparative information where possible to show change from average historical conditions and to provide information that indicates when action thresholds are implicated.

- Ignore scenarios that are not economically feasible.

- Embedding results in animations were of great interest to show the temporal components of water and climate projections.

- When possible, have a bulleted sentence on a figure that simply states the take-home message for decision makers.

Decision makers need training, collaboration, and technical information-Many interviewees, especially early in the study, report limited knowledge about climate variability and change and potential impacts on the water resources of Guam. Current models of recharge, water distribution systems, and stormwater drainage use historic/observed trends about rainfall, sea level, and streamflow. Interviewees suggested that a lack of technical expertise and budget limitations explained why climate projections have not been part of decisions about future water-management options. Most interviewees expressed strong interest in trainings and information exchange to improve understanding of climate variability and change impacts on Guam's water resources. Many expressed the concern that they have insufficient expertise to interpret climate information such as ENSO forecasts, but that such information would be helpful in managing water resources in the face of climate variability.

GWA and NAVFAC expressed interest in working together and communicating about how to manage a shared resource. They support a collaborative dynamic and a need to precoordinate meetings. During the last year of the project, GWA and NAVFAC water managers started regularly meeting under the OneGuam framework to better coordinate, manage, and share information related to water supplies in Guam (see next point for additional information).
New research results are considered interesting and helpful for water management-Respondents generally reported that USGS is considered a trusted source of information and their new research results are interesting and helpful in supporting their efforts to manage water resources on Guam. Several respondents were keen to make sure that their colleagues from other organizations (for example, Consolidated Commission on Utilities) were aware of the results and taking the new information into account in their decision-making processes.

One example of the perceived value of the new results is in support of the OneGuam initiative by NAVFAC Marianas and GWA, which supports decision making aimed at creating a water-management system for Guam that better integrates federal and local government needs and goals. The OneGuam initiative includes a Technical Advisory Group that is a source of scientific expertise for the federal and local partners. A more codified mechanism was recommended for ensuring bidirectional flow of information between decision makers and scientists. For instance, if a decision (for example, to drill a new well or renovate an existing well) is being considered by OneGuam partners, then they should ask scientists to provide the latest data or information relevant to that decision to determine if it is consistent with longterm adaptive management goals (for example, to keep salinity at an acceptable level).

Interviewees generally agreed that the most helpful information displays were maps, especially of example adaptive pumping scenarios in a future-climate scenario. Conveying specific spatial information (for example, how far inland should we move roads and utilities?) was considered important by some interviewees.

Some limitations of the new information were noted by interviewees. For instance, some wanted more detailed description of how accurate the projections of the future climate conditions are (for example, confidence intervals or ranges). Others wondered about how water resources would be affected under future climate projections if two additional management actions were taken: (1) fixing leaky pipes and (2) redirecting stormwater into aquifers to recharge the groundwater supply. For instance, if we reduced leakage by 50 percent, how much of the climate-change impact on supply would that address? Or, if storm water management was more efficient, how would that change the need to consider alternative pumping scenarios? In general, specific analyses would be necessary to support specific objectives of resource managers (for example, if GWA needed the Public Utilities Commission to provide relief, such as through a bond, for a specific capital investment such as drilling new shallower wells). Finally, the new information was viewed as limited by some because of a mismatch with decision-makers' needs. For instance, the timeframe of the future-climate scenario (end of the century) did not correspond well to planning timelines of people responsible for short-term (for example, 3-5 years) decisions. Another example is that information about future reservoir levels needs to be consistent with other tools used by water managers (for example, information should be described so it relates to each GWA water-pressure zone). 
Interviewees recommended summaries separately address four main areas:

- Background concepts: Summaries need to explain the bigger picture, such as (1) how Guam's groundwater and surface-water systems work (for example, what is a watershed and how does it affect the Northern Guam Lens Aquifer?); and (2) that climate change may lead to rainfall decrease which leads to less recharge and(or) increased sediment loads. A graphic of the freshwater lens and how it is impacted by a changing climate should be included. This background information was considered important for both lay and technical audiences.

- Climate projections: A summary of projected changes in key climate variables was considered valuable (for example, rainfall, temperature, days over $90^{\circ} \mathrm{F}$, drought conditions, sea-level rise). This summary could be an updated version of the current two-page document about Guam climate and should include an "as of X date" to indicate when it is published.

- Integrated climate-water model results: Analog conditions were considered most valuable for contextualizing results (for example, drought of record). A recharge map was also considered helpful, as was a threepanel figure showing the separate and combined effects of sea-level rise and decreased rainfall.

- Examples of management options: Summaries need to respond to questions such as "What should I do?" or "How do we implement capital improvement projects (that is, should we invest in changing the distribution or treatment system to deal with unacceptable salinity) to prepare for a 6-percent decrease in rainfall?" Providing information about alternative management scenarios will help make the information actionable (for example, "to avoid salinity problems, Guam needs to drill more wells - only to the recommended depth of 40 feet - with less productivity, rather than maintain fewer wells with more productivity"). A key message several interviewees wanted to convey was that we should not presume rainfall will stay the same; whatever recharge ends up in the aquifer, we need to manage it appropriately so that it is a reliable resource for future generations.

\section{Outreach and Communication Products}

Upon request from stakeholders, several products were created, separate from technical reports and peer-reviewed manuscripts that clearly and concisely summarize the project's background, simplified main findings, and displayed a manageroriented style. These products consisted of: (1) a briefing sheet for managers outlining the watersheds and water systems of Guam, and how climate information is relevant to their future planning (Gingerich and others, 2019a), (2) an information sheet summarizing Guam's historic hydrological and climatological trends with respect to temperature, rainfall, ENSO impacts, sea level, and typhoons (Gingerich and others, 2019b), and; (3) an executive summary of key findings from the study summarizing future climate effects and management options and scenarios. These products are available in hard copy to all stakeholders and university partners and are available electronically on the USGS and PacificRISA.org websites.

\section{Semi-Structured Interview Protocol}

A semi-structured interview protocol guided discussion with interviewees to identify their main responsibilities and duties, specify key decisions affected by climate variables, determine current understanding of climate impacts and use of climate information, and identify climate information needs. Questions that were used to seed the discussion included:

- What are your general thoughts about the proposed project methods and outputs, or potential use of the information that could be generated?

- Which variables or factors in the future climate scenarios are the most interesting or relevant to you and your organization?

- What type of information format would be the most helpful? (for example: maps, reports, and tables.)

\section{Round Two Interview Questions}

\section{Part 1: Background Knowledge of Resources}

\section{Preamble}

What_-We are talking with people who are involved in the management of fresh water on Guam to figure out how we might improve how information is presented.

Why-Our goal is to learn about what, if anything, we could do to make climate and water information more useful to people like you. We are interested in whether you are familiar with the type of information often provided by scientists at USGS or at universities, for instance.

How-In the next 45-60 minutes (or whatever time you have), we'd like to ask you some general questions first about some of the reports that are available and how you might use them. Then we have some specific questions about particular types of information displays.

1. Are you aware of the 2013 USGS report titled: The Effects of Withdrawals and Drought on Groundwater Availability in the Northern Guam Lens Aquifer, Guam? If yes, please answer questions 2-3. If no, skip to question 5 .
A. Yes
B. No 
2. If yes to question 1 :

A. Have you read some part of it or looked at any figures or tables?

B. Have you read all of it?

C. Are you aware of it but have not read it?

3. Please tell us how you have used information in the report (choose as many answers as are applicable):

A. Used information to help me think about the future as is relevant to my job responsibilities;

B. Used information to help make a future infrastructure decision;

C. Used figures or tables from the report in a presentation to other decision makers;

D. Cited information in another report;

E. Used information to justify another planning decision;

F. Used information to request increased financial or human resources to address an issue;

G. Used information to increase my knowledge about Guam's water resources.

H. Other (please list):

I. Have not used the information

Follow up: Please elaborate on any of the specific ways in which you used the information.

4. What information did you find useful in the USGS report? (choose as many answers as applicable)

A. Maps showing vulnerability of wells to saltwater contamination under different pumping rates;

B. Comparison of scenarios showing current well salinity versus future well salinity in potential drought conditions;

C. Comparison of scenarios showing current well salinity versus future well salinity in potential drought conditions WITH military buildup conditions;

D. Maps of how to potentially redistribute pumping to minimize saltwater contamination under different scenarios;

E. Tables providing exact groundwater pumpage rates under current and future conditions and scenarios;

F. Learning about historic climate and groundwater trends on Guam;
G. Other (please list):

5. Are you aware of the USGS published quarterly Fena

Reservoir Report? (If yes, please answer questions 6-7. If no, please skip to question 8):
A. Yes
B. No

6. If yes to question 5:

A. Have you read some part of it or looked at any figures or tables?

B. Have you read all of it?

C. Are you aware of it but have not read it?

7. Please tell us how you have used information in the quarterly Fena Reservoir report (choose as many answers as are applicable):

A. Used information to help me think about the future as is relevant to my job responsibilities;

B. Used information to help make a future infrastructure decision;

C. Used figures or tables from the report in a presentation to other decision makers;

D. Cited information in another report;

E. Used information to justify another planning decision;

F. Used information to request increased financial or human resources to address an issue;

G. Used information to increase my knowledge about Guam's water resources.

H. Other (please list)

I. Have not used the information

Follow up: Please elaborate on any of the specific ways in which you used the information?

8. Are you aware of the NWS Pacific ENSO Applications Climate Center (PEAC Center) quarterly ENSO bulletin and newsletter? (If yes, please answer questions 9-10. If no, please skip to question 11):
A. Yes
B. No

9. If yes to question 8 :

A. Have you read some part of it or looked at any figures or tables?

B. Have you read all of it? 
C. Are you aware of it but have not read it?

10. Please tell us how you have used information in the quarterly PEAC ENSO bulletin (choose as many answers as are applicable):
A. Used information to help me think about the
future as is relevant to my job responsibilities;
B. Used information to help make a future infrastructure decision;
C. Used figures or tables from the report in a presentation to other decision makers;
D. Cited information in another report;
E. Used information to justify another planning decision;
F. Used information to request increased financial or human resources to address an issue;
G. Used information to increase my knowledge about Guam's climate.
H. Other (please list):
I. Have not used the information

Follow up: Please elaborate on any of the specific ways in which you used the information?

11. If you did NOT look at one or any of the three resources discussed above, what were the reasons? (circle as many as applicable)
A. Did not know the resource existed;
B. No time;
C. Not relevant to my job duties;
D. Information was not presented in an understandable manner;
E. Information was not presented in the form I needed;
F. Not enough support to translate the information into practical decisions;

Other (please list):

\section{Part 2: Usability of Tools and Figures}

The following questions refer to previously published figures or tables that were presented to the interviewees.

- Can the interviewee find one piece of information that you ask for?
- Can the interviewee understand the information presented?

- Can the interviewee combine pieces of information, if necessary?

- Does the interviewee like/dislike the way the info is presented?

- What things would you change to make this more informative for/ relevant/ salient to the types of responsibilities you have as part of your job?

\section{Groundwater and Salinity Figures}

12. A red dot on the maps above (next page) indicates a groundwater well that:
A. Is suitable for drinking
B. Has a chloride concentration of over $500 \mathrm{mg}$ per liter
C. Is broken

13. In Scenario A, showing average conditions in 2010 , what is the approximate chloride concentration of the most northern well in Hagåtña?
A. $<200 \mathrm{mg} / \mathrm{L}$
B. $\quad 0.5 \mathrm{Mgal} /$ day
C. $500 \mathrm{mg} / \mathrm{L}$

14. The purpose of Scenario $\mathrm{C}$ is to demonstrate that:
A. Under drought conditions there is no need to change management and pumping of wells
B. The Northern Guam wellfield does not have sufficient freshwater supply to meet needs
C. Under drought conditions, managers can avoid the highest level of saltwater contamination in wells by redistributing pumpage throughout the wellfield

15. The area of simulated greatest freshwater discharge on the coast is in
A. Haputo Bay
B. Tumon Bay
C. Mangilao

16. The groundwater flow patterns predicted by the model indicated that most of the coastal discharge in Haputo Bay is from which basins? 


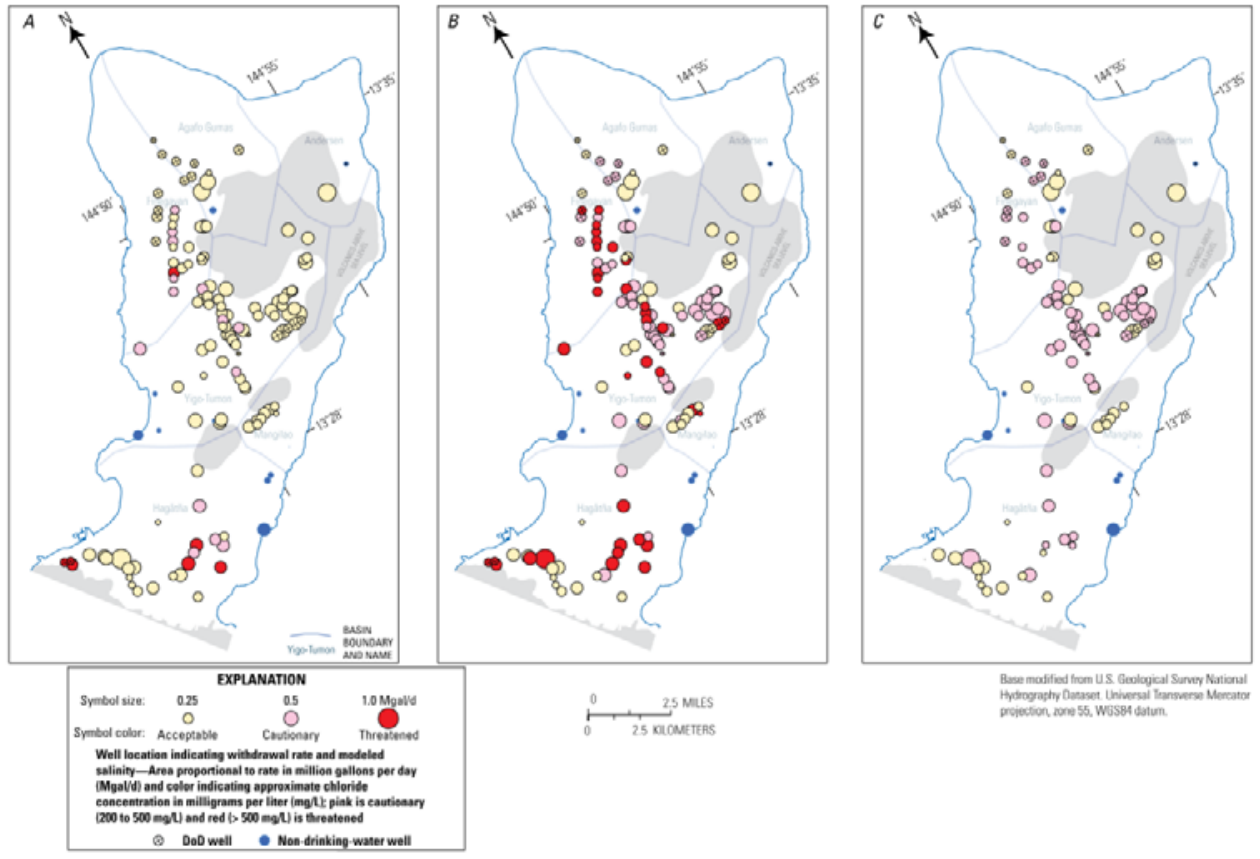

Figure 16. Simulated salinity at pumped wells in the Northern Guam Lens Aquifer, Guam. A, average 2010. B, 5-year drought. C, drought conditions with reduced withdrawal.

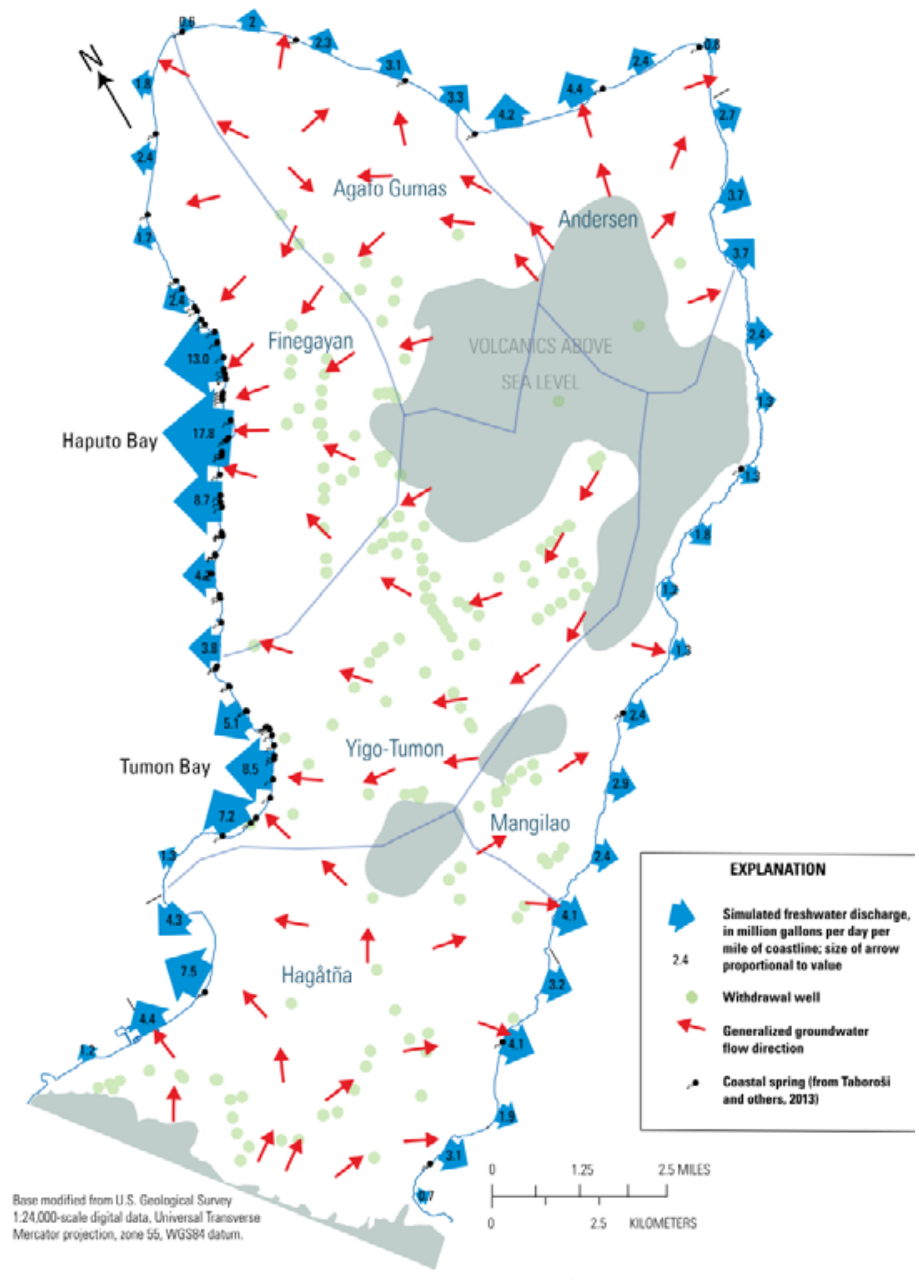

Figure 3.1. Sample image from Gingerich (2013) showing maps of simulated salinity at pumped wells in the Northern Guam Lens Aquifer, Guam for questions 12 through 14.
Figure 3.2. Sample image from Gingerich (2013) showing map of simulated freshwater discharge from the Northern Guam Lens Aquifer, Guam for questions 15 and 16 . 

A. Finegayan
B. Hagåtña
C. Mangilao

17. How many total additional Mgal/day become threatened withdrawal (high salinity levels) under drought (Scenario 4) conditions?
A. $26-5=21 \mathrm{Mgal} / \mathrm{day}$
B. $12.09-2.28=9.81 \mathrm{Mgal} /$ day

C. $81 \mathrm{Mgal} / \mathrm{day}$

18. Which aquifer basin has the greatest increase in high salinity threatened withdrawal from a normal climate (Scenario 3) versus a drought (Scenario 4)?
A. Agafo Gumas
B. Mangilao
C. Yigo-Tumon

Figure 3.3. Sample image of table 5 from Gingerich (2013) that displays expected groundwater withdrawals under different military buildup and drought scenarios for questions 17 and 18 . Scenarios 3 and 4, respectively, show the difference in withdrawals under the same military growth future with and without a drought.
Table 5. Classification of withdrawal for simulated scenarios, Northern Guam Lens Aquifer, Guam.

\begin{tabular}{|c|c|c|c|c|c|c|}
\hline Aquifer basin & $\begin{array}{c}\text { GEPA } 1991 \\
\text { sustainable } \\
\text { yield estimate } \\
(\mathrm{Mgal} / \mathrm{d})\end{array}$ & $\begin{array}{c}\text { Total } \\
\text { simulated } \\
\text { withdrawal } \\
\text { (Mgal/d) }\end{array}$ & $\begin{array}{c}\text { Cautionary } \\
\text { withdrawal } \\
\text { (Mgal/d) }\end{array}$ & $\begin{array}{c}\text { Cautionary } \\
\text { withdrawal } \\
\text { (percent of total) }\end{array}$ & $\begin{array}{l}\text { Threatened } \\
\text { withdrawal } \\
\text { (Mgal/d) }\end{array}$ & $\begin{array}{l}\text { Threatened } \\
\text { withdrawal } \\
\text { (percent of total) }\end{array}$ \\
\hline \multicolumn{7}{|c|}{ Scenario 1-Expected growth (non-USMC) } \\
\hline Agafo Gumas & 12 & 3.10 & 0 & 0 & 0 & 0 \\
\hline Andersen & 10 & 0.79 & 0 & 0 & 0 & 0 \\
\hline Finegayan & 12 & 6.16 & 1.18 & 19 & 0.71 & 12 \\
\hline Hagåtña & 21 & 9.10 & 1.04 & 11 & 1.87 & 21 \\
\hline Mangilao & 7 & 2.18 & 0 & 0 & 0 & 0 \\
\hline Yigo-Tumon & 20 & 23.51 & 1.50 & 6 & 0 & 0 \\
\hline Total & 81 & 44.84 & 3.72 & 8 & 2.58 & 6 \\
\hline \multicolumn{7}{|c|}{ Scenario 2-Expected growth (including USMC) } \\
\hline$\overline{\text { Agafo Gumas }}$ & 12 & 4.89 & 0 & 0 & 0 & 0 \\
\hline Andersen & 10 & 0.79 & 0 & 0 & 0 & 0 \\
\hline Finegayan & 12 & 6.16 & 1.88 & 31 & 0.71 & 12 \\
\hline Hagåtña & 21 & 9.10 & 1.04 & 11 & 1.87 & 21 \\
\hline Mangilao & 7 & 2.18 & 0 & 0 & 0 & 0 \\
\hline Yigo-Tumon & 20 & 23.79 & 1.50 & 6 & 0 & 0 \\
\hline Total & 81 & 46.91 & 4.42 & 9 & 2.58 & 5 \\
\hline \multicolumn{7}{|c|}{ Scenario 3-Expected growth (including redistributed USMC) } \\
\hline Agafo Gumas & 12 & 4.43 & 0 & 0 & 0 & 0 \\
\hline Andersen & 10 & 1.04 & 0 & 0 & 0 & 0 \\
\hline Finegayan & 12 & 5.56 & 1.59 & 29 & 0.41 & 7 \\
\hline Hagåtña & 21 & 9.10 & 1.04 & 11 & 1.87 & 21 \\
\hline Mangilao & 7 & 2.18 & 0 & 0 & 0 & 0 \\
\hline Yigo-Tumon & 20 & 24.31 & 1.50 & 6 & 0 & 0 \\
\hline Total & 81 & 46.62 & 4.13 & 9 & 2.28 & 5 \\
\hline \multicolumn{7}{|c|}{ Scenario 4-Expected growth (including redistributed USMC) with 5-year drought } \\
\hline Agafo Gumas & 12 & 4.43 & 2.45 & 55 & 0 & 0 \\
\hline Andersen & 10 & 1.04 & 0 & 0 & 0 & 0 \\
\hline Finegayan & 12 & 5.56 & 2.00 & 36 & 3.03 & 54 \\
\hline Hagåtña & 21 & 9.10 & 2.25 & 25 & 4.02 & 44 \\
\hline Mangilao & 7 & 2.18 & 0 & 0 & 0.45 & 21 \\
\hline Yigo-Tumon & 20 & 24.31 & 12.90 & 53 & 4.59 & 19 \\
\hline Total & 81 & 46.62 & 19.61 & 42 & 12.09 & 26 \\
\hline \multicolumn{7}{|c|}{ Scenario 5-Redistributed expected growth (including USMC) } \\
\hline Agafo Gumas & 12 & 4.43 & 0 & 0 & 0 & 0 \\
\hline Andersen & 10 & 1.04 & 0 & 0 & 0 & 0 \\
\hline Finegayan & 12 & 5.67 & 1.59 & 28 & 0 & 0 \\
\hline Hagåtña & 21 & 8.87 & 2.27 & 26 & 0 & 0 \\
\hline Mangilao & 7 & 2.18 & 0 & 0 & 0 & 0 \\
\hline Yigo-Tumon & 20 & 24.31 & 1.27 & 5 & 0 & 0 \\
\hline Total & 81 & 46.51 & 5.13 & 11 & 0 & 0 \\
\hline
\end{tabular}


Provisional and subject to revision

Table 2. Monthly and 12-month cumulative rainfall totals for the Fena watershed, Guam

\begin{tabular}{|c|c|c|c|c|}
\hline \multirow[b]{2}{*}{ Month } & \multicolumn{2}{|c|}{ Monthly totals } & \multicolumn{2}{|c|}{ Cumulative totals } \\
\hline & $\begin{array}{l}\text { Monthly rainfall } \\
\quad \text { (inches) }\end{array}$ & $\begin{array}{l}\text { Percent of } \\
\text { long-term } \\
\text { average }\end{array}$ & $\begin{array}{c}\text { 12-month } \\
\text { cumulative } \\
\text { rainfall } \\
\text { (inches) }\end{array}$ & $\begin{array}{l}\text { Percent of } \\
\text { long-term } \\
\text { average }\end{array}$ \\
\hline March 2014 & 3.27 & 115 & 120.84 & 127 \\
\hline April 2014 & 5.42 & 160 & 123.80 & 130 \\
\hline May 2014 & 2.73 & 58 & 119.27 & 125 \\
\hline June 2014 & 5.49 & 93 & 118.87 & 124 \\
\hline July 2014 & 28.15 & 282 & 140.52 & 147 \\
\hline August 2014 & 6.10 & 34 & 136.47 & 143 \\
\hline September 2014 & 18.57 & 134 & 122.79 & 129 \\
\hline October 2014 & 24.81 & 206 & 124.94 & 131 \\
\hline November 2014 & 8.35 & 82 & 128.98 & 135 \\
\hline December 2014 & 5.05 & 73 & 129.18 & 135 \\
\hline January 2015 & 10.87 & 280 & 123.57 & 129 \\
\hline February 2015 & 0.59 & 16 & 119.40 & 125 \\
\hline
\end{tabular}

a Average rainfall for the rain gages used in the modeling for the Fena Watershed (Almagosa and Fena Pump)

\section{Fena Reservoir Management Figures}

19. The table above shows the last year of monthly rainfall and the last 12-month cumulative rainfall in inches. In the context above, can you describe what "percent of long-term average" means? (OPEN ENDED)

20. In 2015 so far, is reservoir stage higher or lower than the 10 -year average?
A. Higher
B. Lower

21. In the EI Niño years shown, is reservoir stage higher or lower than the 10-year average?
A. Higher
B. Lower

22. At what reservoir stage (feet) does the first level of water conservation measures begin?
A. 66 feet
B. 110 feet
C. 80 feet

Figure 3.4. Sample image of table 2 from Rosa and Hay (2017a) that displays monthly and 12-month cumulative rainfall totals for the Fena watershed, Guam for question 19.

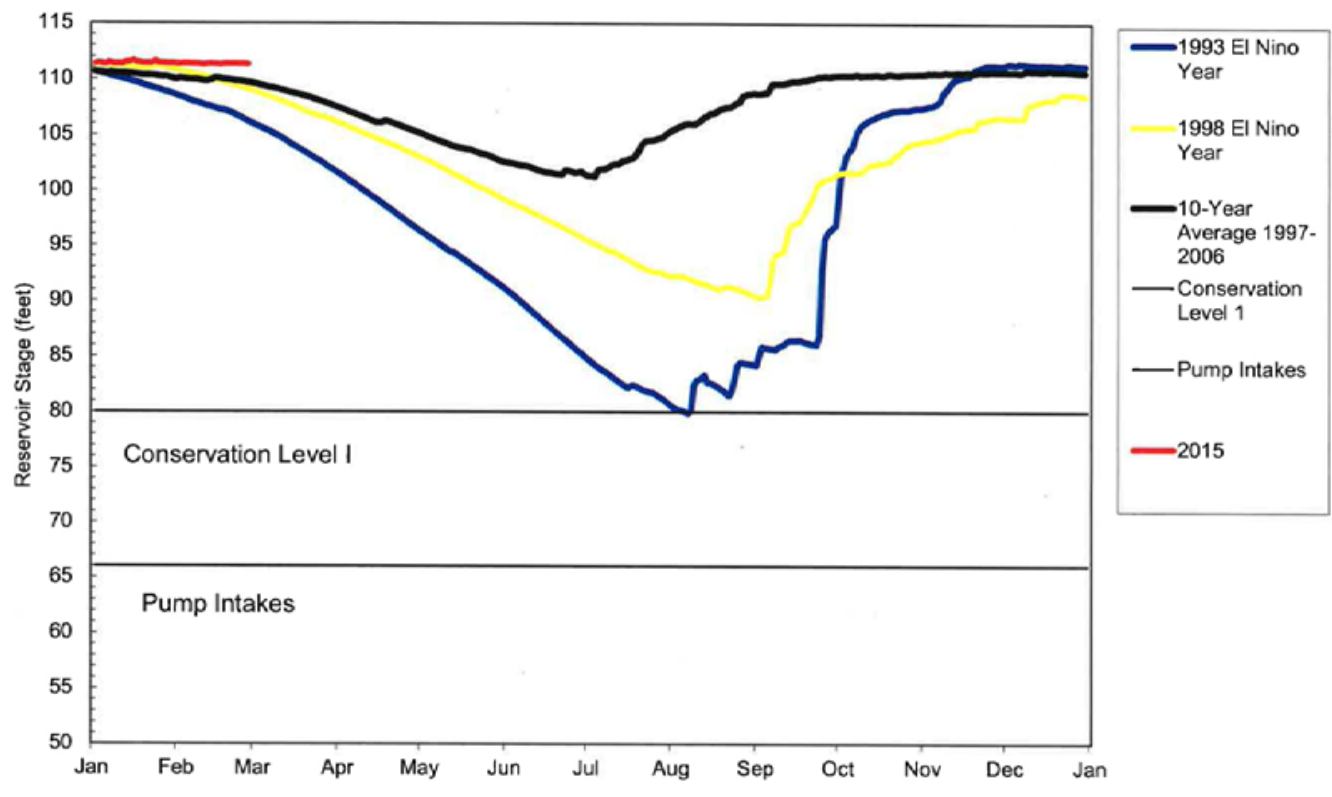

Figure 4. Fena Reservoir stage for selected years, 1993-2015
Figure 3.5. Sample image that shows the hypothetical water level of the Fena Reservoir during different notable climate events and over a 10-year average for questions 20 through 22. Data collected to this point in 2015 are shown in red. 


\section{Storm Track Figures}

23. What is the approximate average annual number of tropical storms and typhoons that pass near Guam?
A. $6-7$
B. $4-5$
C. 8

24. How many storms passed near Guam in 1997 ?
A. 8
B. 4
C. 0

25. What is the approximate simulated historical probability of 3 storms or typhoons passing near Guam in a year?
A. About $15 \%$
B. About $20 \%$
C. About $25 \%$

26. According to the figure comparing future projected number of storms to historical number of storms:
A. There is an increased probability of a GREATER TOTAL number of storms passing near Guam in the future
B. There is an increased probability of FEWER TOTAL number of storms passing near Guam in the future
C. There is an increased probability of MORE INTENSE storms passing near Guam in the future

Figure 3.6. Sample image that shows a hypothetical climatology of observed tropical storm and typhon frequency from 1979 to 2012 for questions 23 and 24.

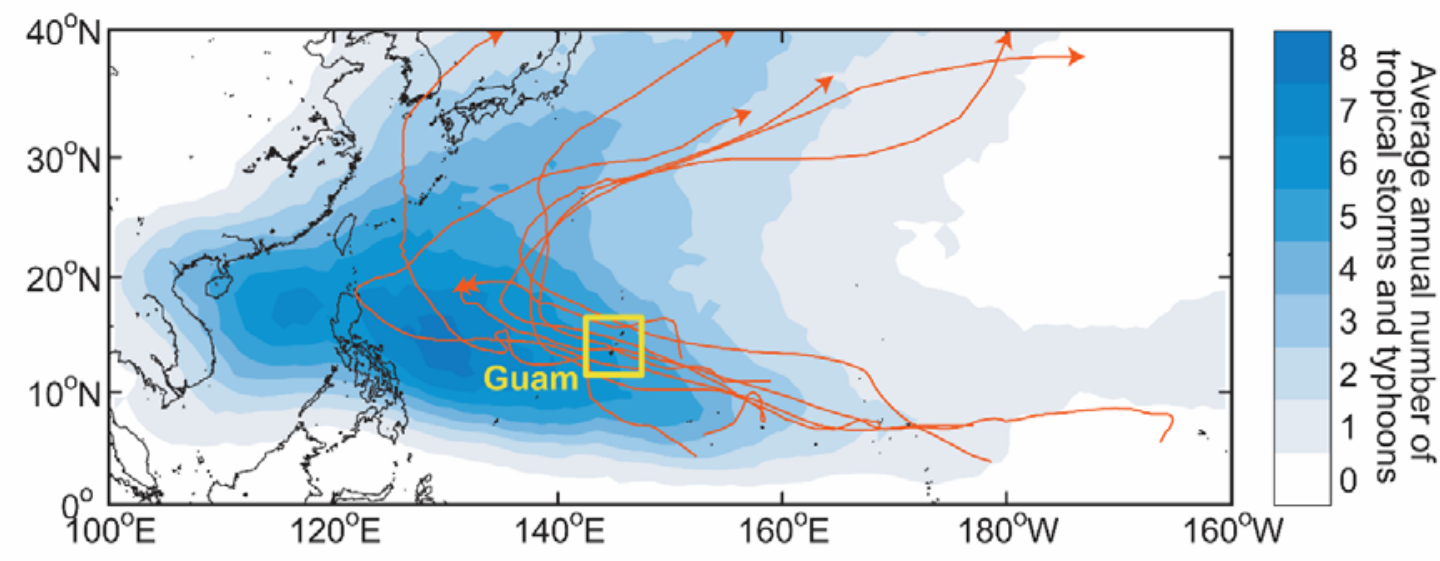

Climatology (1979-2012) of observed tropical storm and typhoon frequency (blue shading). Storm tracks passing near Guam during 1997—one of the busiest typhoon seasons in the northwestern Pacific - are indicated. 


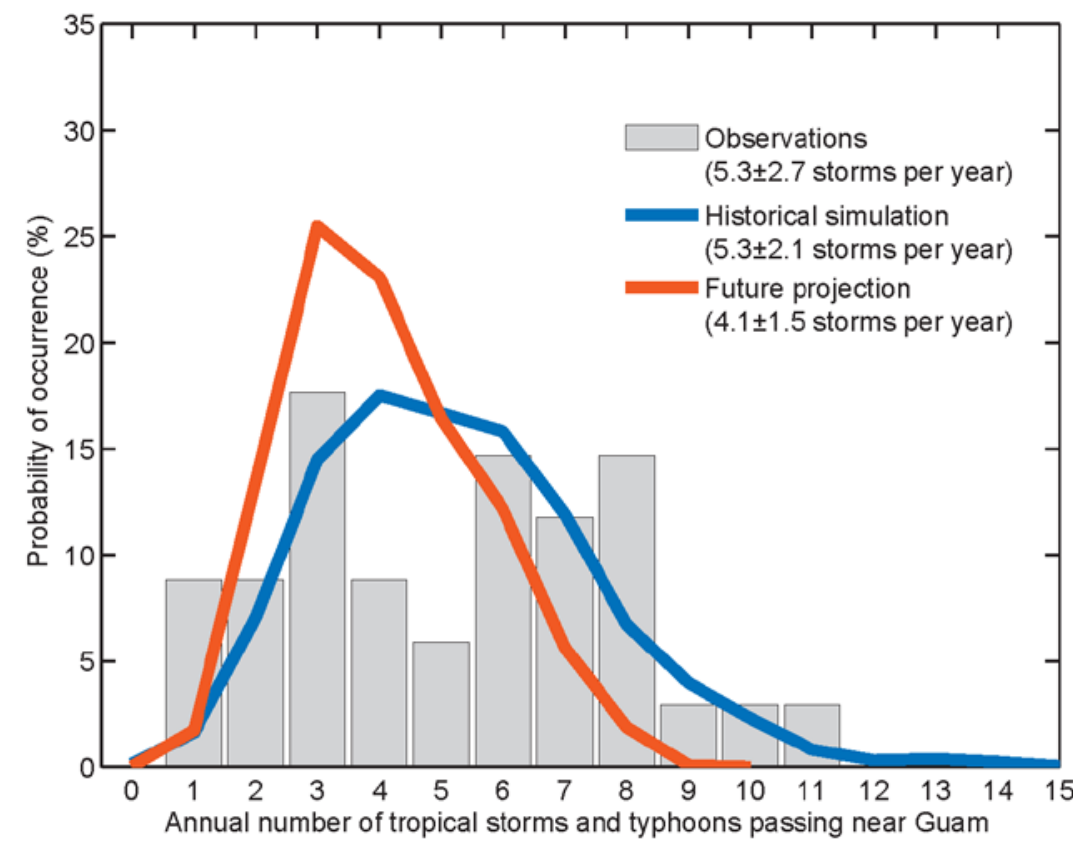

Figure 3.7. Bar chart that shows the hypothetical frequency of tropical storms and typhoons for observations of 1979 to 2012 and simulations of the historical period of 1976 to 2005 and future climate of 2071-2100 with greenhouse warming for questions 25 and 26 .

Frequency of tropical storms and typhoons for observations (1979-2012), simulations of the historical period (1976-2005) and the future climate with greenhouse warming (2071-2100). Thick lines indicate the multi-model average of four individual simulations. Mean and likely range of storm counts are listed. Simulations are scaled to remove model biases in storm genesis and tracks.

\section{Questions Guiding the Interviews:}

- When considering the new results from the USGS research, which information is most important from your perspective (for example, assumptions, new findings, methodological details)?

- What figures or tables do you find most useful?

- What changes are needed (especially to figures or tables) to make the information more useful?
- What kind of additional contextual information is needed to help a user make sense of the findings?

- Are there key messages from the research findings that you worry might be overlooked?

- What information would assist Guam Government and NAVFAC to work together to manage future freshwater supply on Guam? 
